EUCLIDES REAME JUNIOR

\title{
FATORES CRÍTICOS DE SUCESSO NA GESTÃO DE PROJETOS COLABORATIVOS DE DESENVOLVIMENTO DE MÁQUINAS AGRÍCOLAS: UM ESTUDO DE CASO
}

Dissertação apresentada à Escola de
Engenharia de São Carlos, da
Universidade de São Paulo, para a
obtenção do título de Mestre em
Engenharia de Produção.

Área de Concentração: Processos e Gestão de Operações.

Orientador: Prof. Dr. Daniel Capaldo Amaral

São Carlos

2008 
AUTORIZO A REPRODUÇĀO E DIVULGAÇÄO TOTAL OU PARCIAL DESTE TRABALHO, POR QUALQUER MEIO CONVENCIONAL OU ELETRÔNICO, PARA FINS DE ESTUDO E PESQUISA, DESDE QUE CITADA A FONTE.

Ficha catalográfica preparada pela Seçāo de Tratamento da Informação do Serviço de Biblioteca - EESC/USP um estudo de caso / Euclides Reame Junior ; orientador Daniel Capaldo Amaral. -- São Carlos, 2008.

Dissertação (Mestrado-Programa de Pós-Graduação e Área de Concentração em Engenharia de Produção) -- Escola de Engenharia de São Carlos da Universidade de São Paulo, 2008 .

1. Fatores críticos de sucesso. 2. Máquinas agricolas. 3. Projetos colaborativos. I. Título. 
Candidato: Bacharel EUCLIDES REAME JUNIOR

Dissertação defendida e julgada em 01/09/2008 perante a Comissão Julgadora:

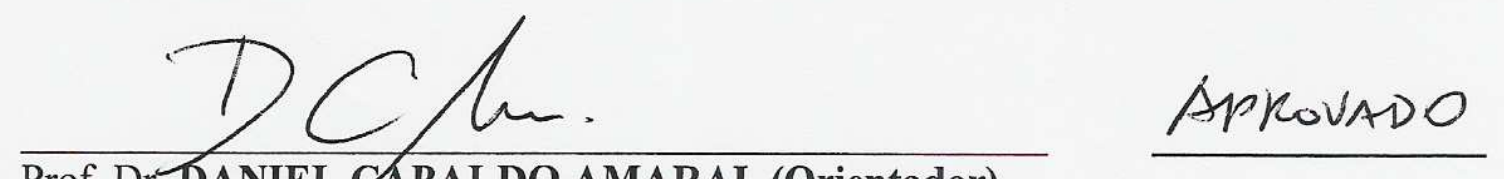

Prof. Dr. DANIEL CAPALDO AMARAL (Orientador)

(Escola de Engenharia de São Carlos/USP)
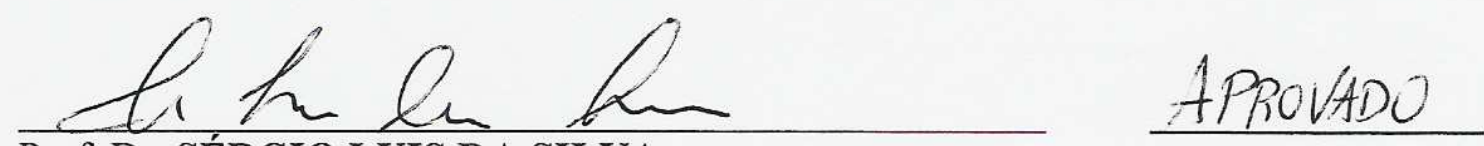

Prof. Dr. SÉRGIO LUIS DA SILVA

(Universidade Federal de São Carlos/UFSCar)

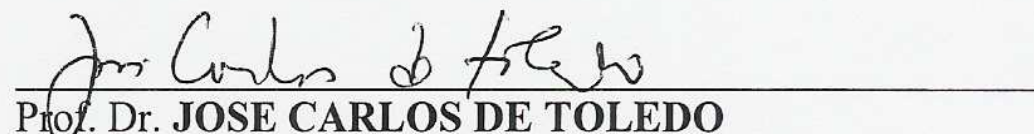

APROUADO.

(Universidade Federal de São Carlos/UFSCar)

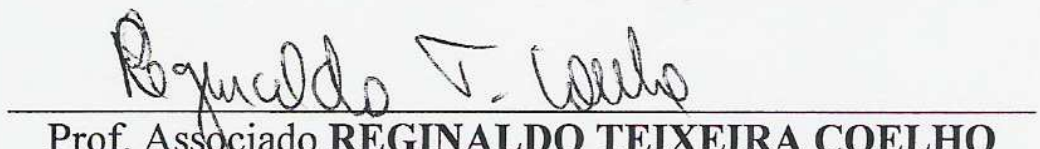

Prof. Associado REGINALDO TEIXEIRA COELHO

Coordenador do Programa de Pós-Graduação em

Engenharia de Produção

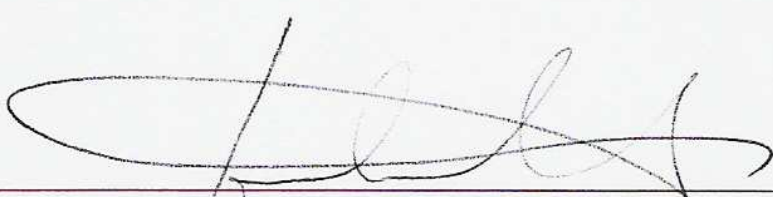

Prof. Associado GERALDO ROBERTO MARTINS DA COSTA

Presidente da Comissão da Pós-Graduação da EESC 
Dedico este trabalho à minha esposa Gisela Helmbrecht Reame por toda a paciência e compreensão 


\section{Agradecimentos}

Ao criador do universo, por tudo.

Agradeço aos meus pais, Euclides e Hebe, que em suas simplicidades entenderam o meu caminho dando-me todo o amor.

Ao meu irmão Eduardo e a minha tia Primitiva Zapata Montanari, pelo incentivo e apoio.

Ao meu orientador, o Professor Doutor Daniel Capaldo Amaral, por todas as orientações, pela paciência interminável, pelo profissionalismo e ética transmitidos durante todo o tempo.

Ao Professor Doutor Henrique Rozenfeld, pelos seus ensinamentos, exemplo de trabalho e profissionalismo acadêmico.

Aos professores, Luiz César Ribeiro Carpinetti, José Carlos de Toledo, Sérgio Luis da Silva, com quem tive a oportunidade de me aprimorar um pouco mais em minha vida acadêmica.

Às amigas e pesquisadoras do Núcleo de Manufatura Avançada (NUMA), Angelita e Camila, por toda a colaboração e atenção. Ao amigo e pesquisador Eduardo Vicenti Albertin pela contribuição quanto ao roteiro de pesquisa deste trabalho.

Às amigas e pesquisadoras da Universidade Técnica Federal do Paraná (UTFPr), Amanda e Oksana, também pela colaboração e atenção.

Aos meus amigos de pesquisa, Edivandro, João, Mauro, Juliana, Maicon, Janaína, Sayuri e ao Danilo pelas experiências e companheirismo.

Ao amigo Paulo Francisco Sprovieri, um excelente professor.

A Simone, pelo apóio técnico e administrativo.

Ao pessoal da SEP, pela ajuda, principalmente ao José Luiz.

À empresa que me ajudou a realizar o trabalho de campo.

À universidade pública, um símbolo de progresso e aprimoramento científico. 


\section{Epígrafe}

"A educação faz um povo fácil de ser liderado, mas difícil de ser dirigido; fácil de ser governado, mas impossível de ser escravizado"

(Henry Peter) 


\section{Resumo}

REAME Jr., E. Fatores críticos de sucesso na gestão de projetos colaborativos de desenvolvimento de máquinas agrícolas: um estudo de caso. Dissertação (Mestrado) Escola de Engenharia de São Carlos, Universidade de São Paulo, São Carlos, 2008.

Os projetos de desenvolvimento realizados em colaboração são fundamentais para que as empresas de máquinas agrícolas consigam aumentar o grau de inovação em produtos, permitindo-as acompanhar os novos desafios de um mercado mais competitivo. Há na literatura vários trabalhos que identificam fatores críticos de sucesso (FCS) para projetos colaborativos, porém, não há muitos estudos sobre a verificação desses fatores no Brasil, em especial na Indústria de Máquinas Agrícolas (IMA). Este trabalho tem como objetivo verificar se os FCS identificados na literatura poderiam ser empregados nesse contexto. Empreendeu-se uma revisão bibliográfica para identificar os "fatores críticos de sucesso" em projetos colaborativos de desenvolvimento de produtos e uma revisão sobre Indústria de Máquinas Agrícolas (IMA), de forma a entender as especificidades desse setor no Brasil. Em seguida, realizou-se um levantamento em uma empresa do setor, com nível de maturidade elevado em desenvolvimento de produto, medido conforme Simões (2007), para verificar se os FCS identificados poderiam ser utilizados em levantamentos no setor e verificar se não havia outros fatores a serem considerados, específicos para o segmento e região. Utilizou-se o método do estudo de caso único, do tipo incorporado. A unidade de análise é constituída por projetos do tipo colaborativo, realizados com sucesso pela empresa. Foram analisados dois projetos de produtos inovadores, com diferentes tipos de parceiro: um com um cliente e outro com um fornecedor. Os dados foram coletados por meio de entrevistas e o instrumento de pesquisa é um roteiro. As instalações da empresa foram visitadas com o objetivo de conhecer os projetos analisados. Como resultado afirma-se que há fatores descritos na literatura que podem não ser críticos; indica-se a existência de novos FCS e reforça-se a importância dos fatores ligados à Garantia de Igualdade e Fatores Universais de Sucesso. A contribuição do trabalho é uma lista de fatores críticos de sucesso que podem servir como passo inicial para levantamentos gerais de campo no setor industrial estudado.

Palavras-chave: fatores críticos de sucesso, máquinas agrícolas, projetos colaborativos. 


\begin{abstract}
REAME Jr., E. Critical success factors in the administration of collaborative projects of development of agricultural machines: a case study. Dissertation (Master's degree) School of Engineering of São Carlos, University of São Paulo, São Carlos, 2008.
\end{abstract}

The collaborative projects of development are one of the main tools in order to agricultural machines companies get to increase the innovation degree in products, allowing them to follow the new challenges of a more competitive market. There is in the literature several works that identify critical success factors (CSF) for collaborative projects; however, there are not many studies about the verification of those factors in Brazil, especially in the Agricultural Machinery Industry. The aim of this work is to verify if identified CSF in the literature could be used in that context. A bibliographical revision was undertaken to identify the "critical success factors" in collaborative projects of development of products and a revision on Agricultural Machines Industry in order to understand the specificities of that section in Brazil. After that it has taken place a survey in a company of that sector, with high level of maturity in development of measured product according to Simões (2007), to verify if identified CSF could be used in surveys in that sector and to verify if there were any other factors to be considered, specific for that segment and field. A case study was used and the units of analysis are collaborative projects accomplished successfully by the company. Two projects development of products were analyzed, with different kinds of partner: one with a customer and the other with a supplying company. Besides the interviews it has taken visits to the companies in order to know the analyzed projects. There are factors described that could not be critical; the results indicate the existence of new critical factors and they confirm the importance of equality and universal factors as critical for collaborative projects. The main contribution of these projects is a list of critical factors of success that one can serve as initial step for general survey in this field.

Key-words: critical success factors (CSF), agricultural machinery, collaborative project. 


\section{Lista Figuras}

Figura 1. Classificação da IBK conforme a estrutura do CNAE........................................... 24

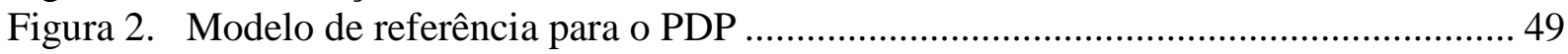

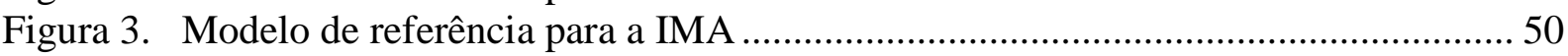

Figura 4. Tipologias de projetos para desenvolvimento de produtos .................................... 59

Figura 5. Modelo do ciclo de vida para o gerenciamento das equipes virtuais....................... 61

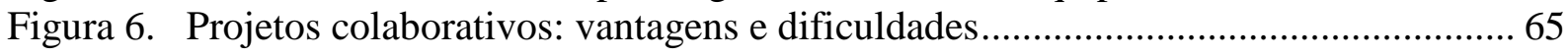

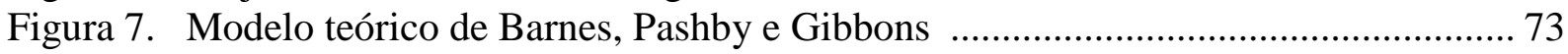

Figura 8. Visão geral do gerenciamento de riscos de um projeto......................................... 79

Figura 9. Síntese dos FCS relacionados no modelo de Barnes, Pashby e Gibbons ............... 84

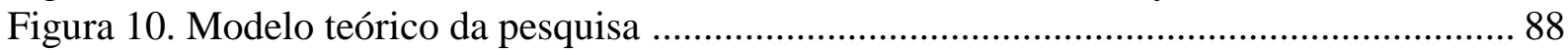

Figura 11. Tipos básicos de projetos de estudo de caso ........................................................ 93

Figura 12. Organograma da área de engenharia da empresa estudada .................................. 99 


\section{Lista de Gráficos}

Gráfico 1. Dispêndios com investimentos em desenvolvimento tecnológico ....................... 17

Gráfico 2. Volume de produção e vendas no período 2000 a 2006....................................... 27

Gráfico 3. Parceiros nas relações de colaboração com a indústria....................................... 42

Gráfico 4. Objetivos da colaboração (triênio 2001 - 2003) ................................................. 43

Gráfico 5. Tipos de projetos de desenvolvimento de produtos da empresa estudada ........... 101

Gráfico 6. FCS da área Gerenciamento de Projeto no projeto com o cliente....................... 109

Gráfico 7. FCS da área Fatores Universais de Sucesso no projeto com o cliente ................ 110

Gráfico 8. FCS da área Gerente do Projeto no projeto com o cliente .................................. 111

Gráfico 9. FCS da área Avaliação do Parceiro no projeto com o cliente ............................. 112

Gráfico 10. FCS da área Garantia de Igualdade no projeto com o cliente ............................. 113

Gráfico 11. FCS da área Influências do Ambiente no projeto com o cliente.......................... 113

Gráfico 12. FCS da área Gerenciamento do Projeto no projeto com o fornecedor ................. 117

Gráfico 13. FCS da área Fatores Universais de Sucesso no projeto com o fornecedor .......... 118

Gráfico 14. FCS da área Gerente do Projeto no projeto com o fornecedor............................ 119

Gráfico 15. FCS da área Avaliação do Parceiro no projeto com o fornecedor ...................... 120

Gráfico 16. FCS da área Garantia de igualdade no projeto com o fornecedor ........................ 121

Gráfico 17. FCS da área Influência do ambiente no projeto com o fornecedor ..................... 121

Gráfico 18. Comparação entre os projetos colaborativos .................................................... 133 


\section{Lista de Quadros}

Quadro 1. Principais fabricantes de máquinas agrícolas no Brasil....................................... 28

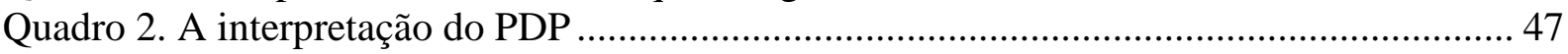

Quadro 3. Síntese da interpretação sobre a colaboração no DP ........................................... 52

Quadro 4. Áreas de conhecimento e os grupos de processos de ........................................... 58

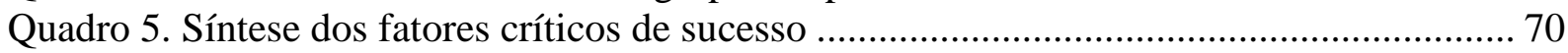

Quadro 6. Setores de atividades e número total de funcionários por área ............................. 98

Quadro 7. Comparação do nível de maturidade da empresa estudada ................................. 103

Quadro 8. Os objetivos da colaboração entre a empresa e demais organizações ................... 105

Quadro 9. Comparação dos FCS do modelo teórico e os FCS dos projetos colaborativos.... 125 


\section{Lista de Tabelas}

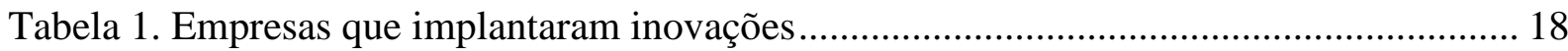

Tabela 2. Características das dimensões do PDP por grupo ................................................. 38

Tabela 3. Relação da colaboração para a inovação ................................................................ 40

Tabela 4. Percentual de participação por área - projeto colaborativo empresa e o cliente..... 126

Tabela 5. Percentual de participação por área - projeto colaborativo empresa e fornecedor . 128

Tabela 6. Variação percentual por área entre os dois projetos colaborativos. 


\section{Lista de abreviaturas e siglas}

ABIMAQ - Associação Brasileira das Indústrias de Máquinas e Equipamentos

AIPM - Australian Institute for Project Management

ANFAVEA - Associação Nacional dos Fabricantes de Veículos Automotores

APM - Association for Project Management

CAD - Computer-Aided Design - desenhos auxiliados por computador

CNAE - Cadastro Nacional de Atividades Econômicas

FCS - Fatores Críticos de Sucesso

GP - Gerenciamento de Projeto

IBGE - Instituto Brasileiro de Geografia e Estatística

IBK - Indústria de Bens de Capital

IMA - Indústria de Máquinas Agrícolas

IPMA - International Project Management Association

ISIC - International Standard Industrial Classification of all Economic Activities

ISO - International Organization for Standardization

MDIC - Ministério do Desenvolvimento, Indústria e Comércio Exterior

MODERFROTA - Programa de Modernização de Tratores da Frota Agrícola e Implementos Associados e Colheitadeiras

MR - Modelo de Referência

NACE - Nomenclature Générale des Activitiés Économiques dans lês Commnautees

Européennes

NCM - Nomenclatura Comum de Mercadoria

OCDE - Organização para Cooperação e Desenvolvimento Econômico

ONU - Organização das Nações Unidas

P\&D - Pesquisa e Desenvolvimento

PDP - Processo de Desenvolvimento de Produto

PINTEC - Pesquisa de Inovação Tecnológica

PMBoK - Project Management Body of Knowledge

PMI - Project Management Institute

RAE - Revista de Administração de Empresas

RBI - Revista Brasileira de Inovação

SPG - Sistema de Posicionamento Global

TI - Tecnologia da Informação

UE - União Européia 


\section{Sumário}

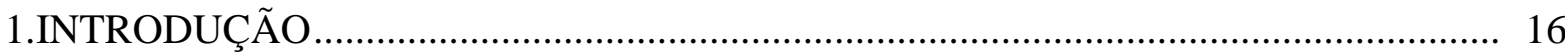

2.INOVAÇÃO E DESENVOLVIMENTO DE PRODUTO NA INDÚSTRIA DE MÁQUINAS AGRÍCOLAS BRASILEIRA ............................................................... 21

2.1.Importância econômica e características da indústria de bens de capital....................... 21

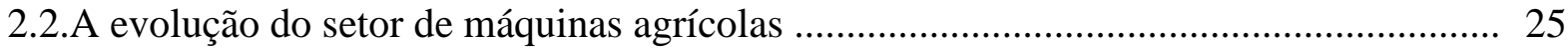

2.3.Características gerais do setor de máquinas agrícolas .................................................. 27

2.4.A inovação tecnológica no setor de máquinas agrícolas ............................................. 30

2.5.O Processo de desenvolvimento de produtos no setor de máquinas agrícolas................ 34

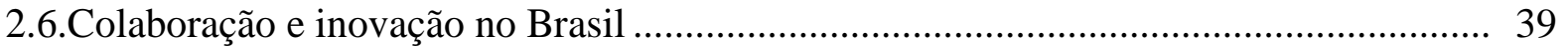

3.A COLABORAÇÃO NO DESENVOLVIMENTO DE PRODUTOS ........................... 44

3.1.O processo de desenvolvimento de produtos (PDP) ...................................................... 44

3.2.O papel da colaboração no desenvolvimento de novos produtos................................. 51

3.3. Gerenciamento de projetos colaborativos ................................................................ 53

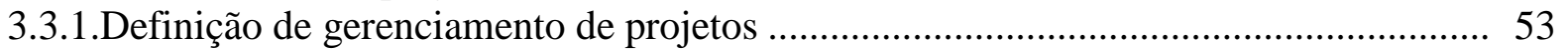

3.3.2.Definição e tipologias de projetos colaborativos..................................................... 59

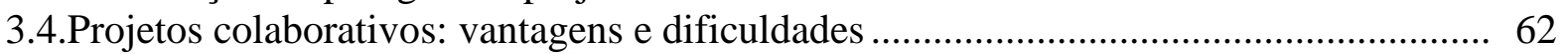

4.MODELOS DE FATORES CRÍTICOS DE SUCESSO NO GERENCIAMENTO DE

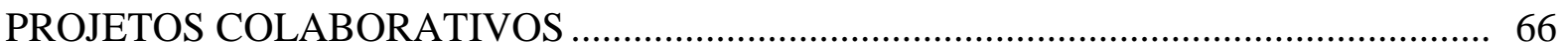

4.1.Definição e revisão dos fatores críticos de sucesso em projetos colaborativos................ 66

4.2.O modelo teórico de Barnes, Pashby e Gibbons ..................................................... 71

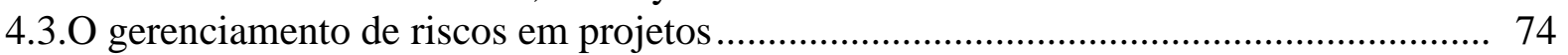

4.4.Síntese dos FCS do modelo de Barnes, Parshby e Gibbons ......................................... 80

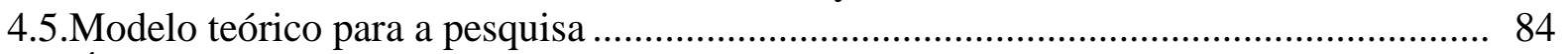

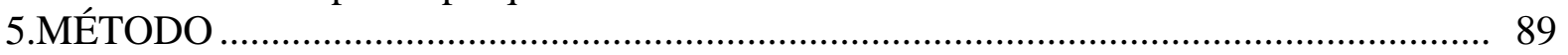

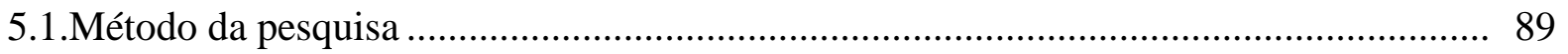

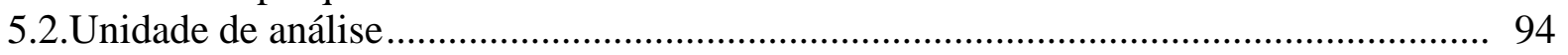

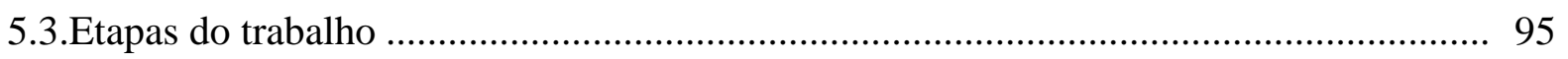

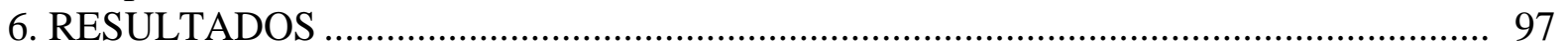

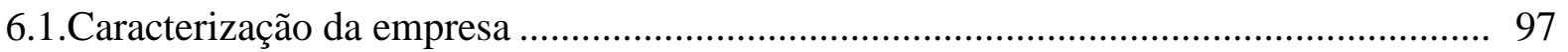

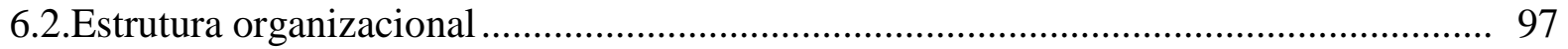

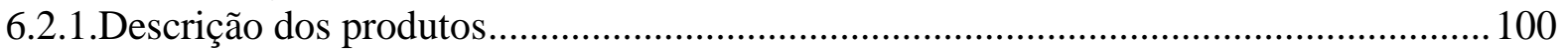

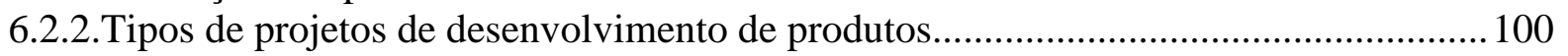

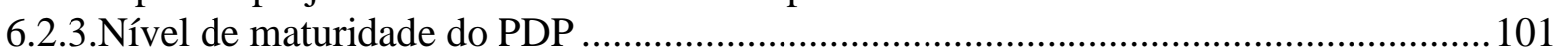

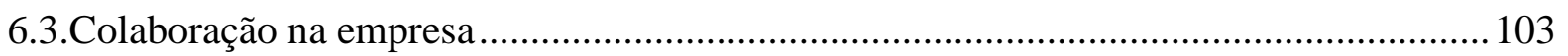

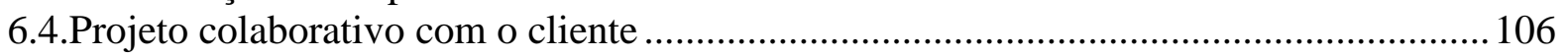

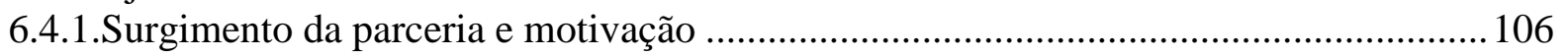

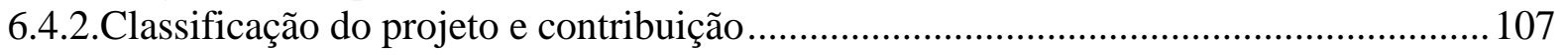

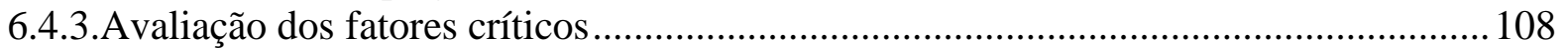

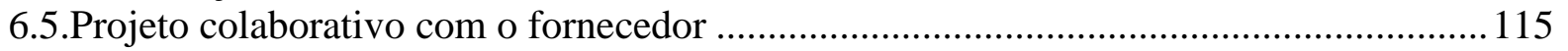

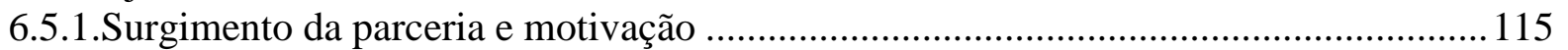

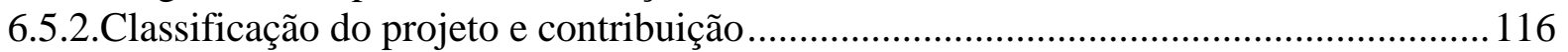

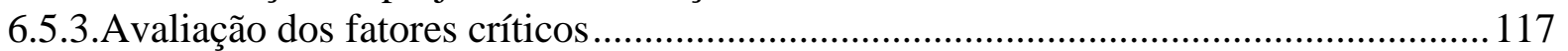

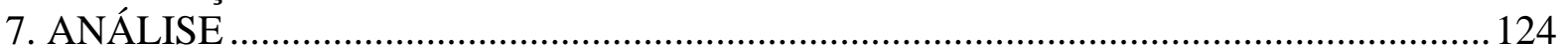

7.1.Análise dos FCS observados no projeto colaborativo entre a empresa e cliente ............. 126

7.2.Análise dos FCS observados no projeto colaborativo entre a empresa e o fornecedor... 128

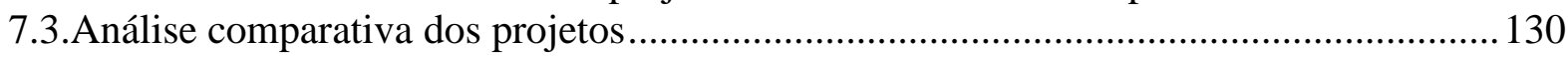




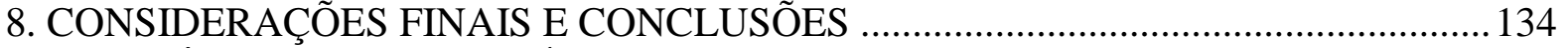

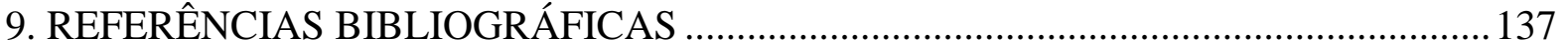

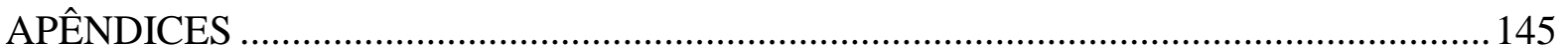




\section{INTRODUÇÃO}

A necessidade de inovar e a realização de projetos em colaboração vêm despertando a atenção da comunidade científica internacional. Estudos e pesquisas comprovam essa realidade. Eis alguns: Domazet et al (2000), Parker (2000), Holmström et al (2002), Emden, Calantone e Droge, (2006), Bstieler (2006), e Knudsen (2007). No caso brasileiro, a Indústria de Máquinas Agrícolas (IMA) está entre aquelas em que esse desafio é mais premente. Em primeiro lugar, pelo grau de inovação tecnológica por que passa o setor. Vive-se uma transição de equipamentos cuja base tecnológica tradicional mecânica (materiais, pneumática, hidráulica, etc.) está sendo revista. Novas tecnologias, como a eletrônica, de software, sensoriamento e comunicação de dados, por exemplo, vêm sendo incorporadas pelas empresas líderes mundiais, permitindo a criação de uma nova geração de máquinas e equipamentos. Esse fenômeno é conhecido como agricultura de precisão, pois essas novas tecnologias podem gerar máquinas e implementos capazes de tratar de maneira específica cada parcela da terra, planta ou animal (no caso de máquinas e implementos para criação animal). O segundo motivo é que a IMA exerce um papel fundamental na agricultura, possibilitando aumentos de produtividade em uma área estratégica para o país. De acordo com uma pesquisa mensal do IBGE (2008), as safras brasileiras de cereais, leguminosas e oleaginosas podem chegar a 142,6 milhões de toneladas em 2008 e bater o recorde produtivo de 2007 que foi da ordem de 133,1 milhões de toneladas. A estimativa do IBGE para o ano de 2008 é de uma colheita 7,2\% maior em relação à do ano de 2007. A IMA contribui diretamente para isso, pois a mecanização da produção agrícola é um dos fatores fundamentais que explicam o nível elevado de desempenho. A IMA integra a cadeia agroindustrial e é considerada nos levantamentos governamentais como parte da indústria de máquinas e equipamentos. Um fato importante é que as empresas industriais brasileiras realizam investimentos em 
desenvolvimento tecnológico feitos por meio da aquisição de máquinas e equipamentos. $\mathrm{O}$ gráfico 1 apresenta uma comparação entre os anos de 2003 a 2005, demonstrando um acréscimo nos percentuais de investimento em inovação dirigido à aquisição de máquinas e equipamentos pelas industrias brasileiras. Portanto, essas empresas possuem um papel indutor da inovação nos demais setores da economia. No caso da IMA, para a agroindústria.

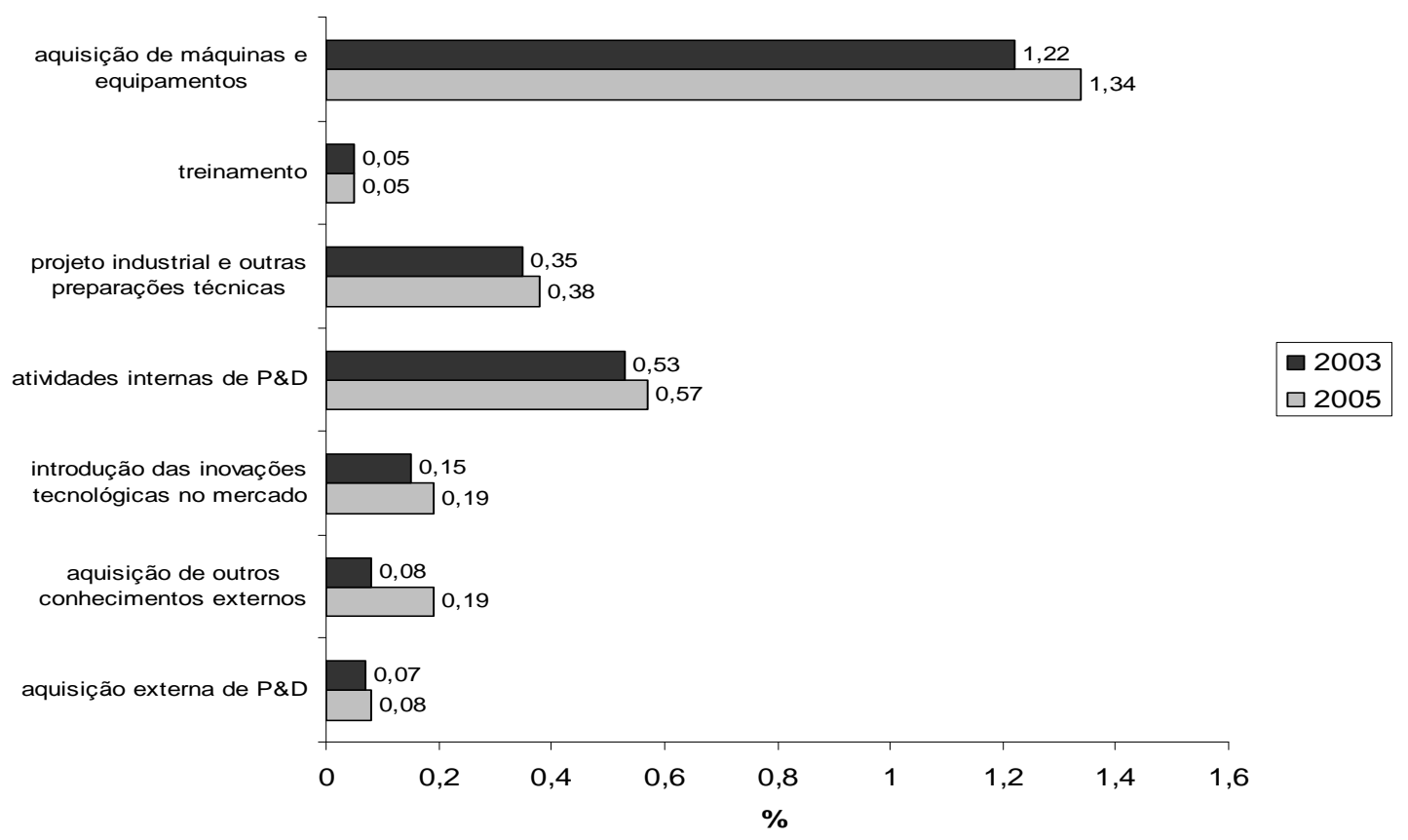

Gráfico 1. Dispêndios com investimentos em desenvolvimento tecnológico (base de cálculo: receita líquida de vendas, período 2003 a 2005)

Fonte. IBGE (2007a)

O setor de máquinas possui ainda um papel significativo na inovação. A tabela 1 descreve dados do setor "Fabricação de Máquinas e Equipamentos", onde se enquadram as empresas de máquinas agrícolas. Na tabela é possível verificar que a taxa de inovação do setor de máquinas e equipamentos é superior à média nacional em termos de inovação no produto. A primeira linha da referida tabela, "Total", apresenta a soma de todas as empresas que participaram da pesquisa (indústrias extrativas, de transformação e serviços, perfazendo um total de 95.300 empresas). Nesta mesma linha, verifica-se que houve $21 \%$ de empresas 
com inovação significativa no produto, sendo $17 \%$ em um novo produto para a empresa e $4 \%$ em um novo produto para o mercado nacional. Observando o segmento de Fabricação de Máquinas e Equipamentos (5.799 empresas), na segunda linha, nota-se que a mesma taxa foi de 30\%. Embora não seja possível dizer que essa mesma proporção é válida para a indústria de máquinas agrícolas, sem dúvida, estes dados são indícios que o segmento mereça a atenção dos pesquisadores.

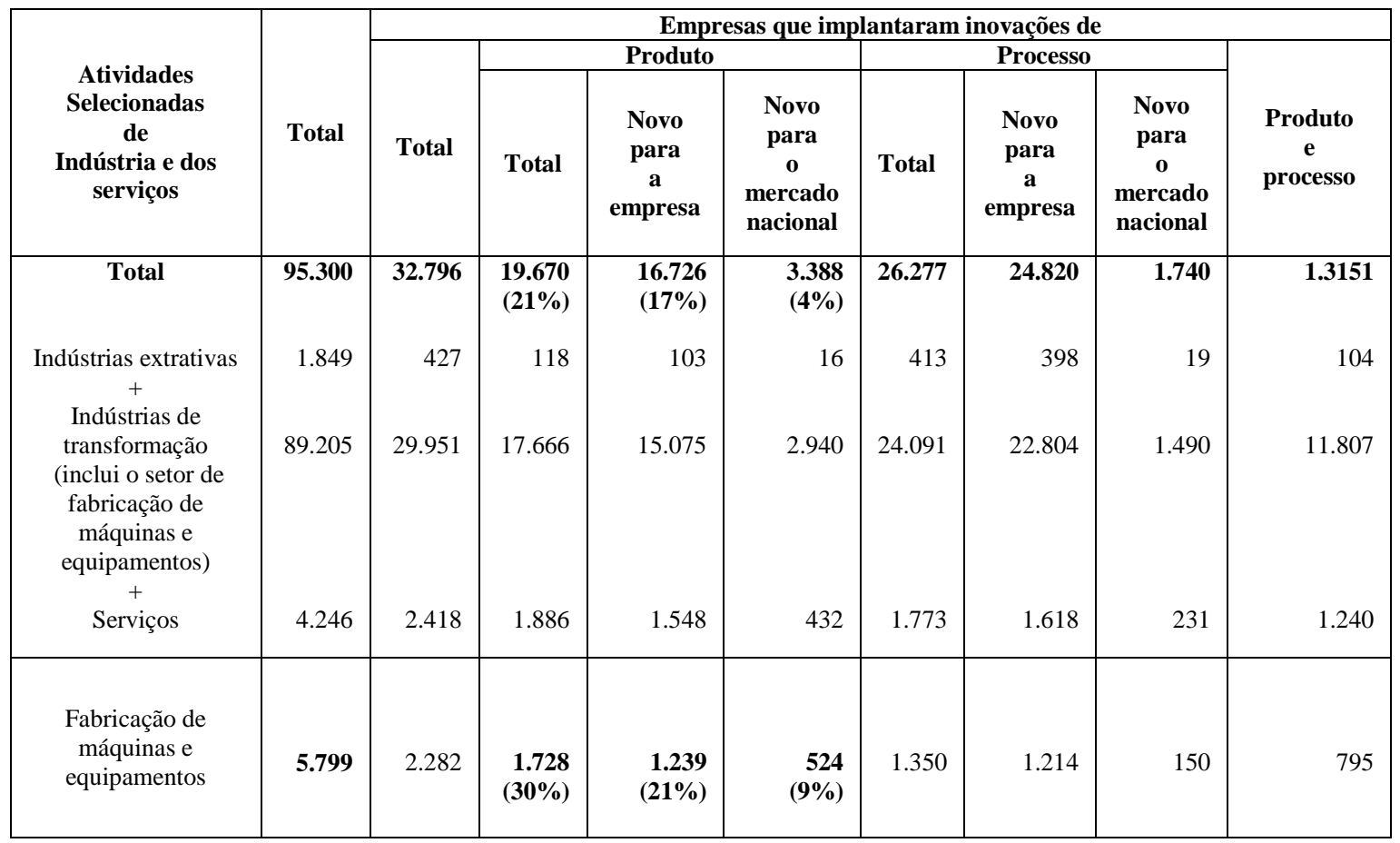

Tabela 1. Empresas que implantaram inovações

(Brasil-período-2003 a 2005)

Fonte: IBGE (2007a)

Além dos dados acima, outras informações reforçam a escolha da IMA. Stulzer (2008) relata que no período de março/2007 a março/2008, as vendas internas de máquinas agrícolas no Brasil cresceram 43,4\%, a produção cresceu 33,2\% e as exportações cresceram 31\%. Nicoletta (2008) enfatiza que o aumento nos preços dos grãos elevou as vendas de colheitadeiras e tratores. Ainda segundo esse autor, o mercado de colheitadeiras e tratores para cana cresceu nos últimos cinco a seis anos e atinge um patamar quase estável em 2008 com previsões de um avanço de 2009 a 2012, crescendo de 10 a $15 \%$ a partir de 2009. Para 
que a IMA continue atuando dessa forma, será fundamental a incorporação das novas tecnologias, atualizando-se frente ao movimento da agricultura de precisão. E uma das estratégias é o avanço em pesquisas e no desenvolvimento de novos produtos por meio da colaboração com outras organizações (clientes, fornecedores, universidades, institutos de pesquisa). Neste contexto, as técnicas e métodos de gerenciamento de projetos são essenciais, pois essas empresas terão que lidar com projetos mais complexos e que envolvam recursos externos. E para que os projetos apresentem resultados satisfatórios nos prazos determinados, é preciso identificar quais são os FCS no gerenciamento dos projetos colaborativos na IMA, de forma que se possa avançar para o aprimoramento das técnicas de gerenciamento deste tipo de projeto, auxiliando no desafio de ampliar a colaboração nessa indústria. É necessário, portanto, desenvolver modelos teóricos que permitam avaliar a situação dessas empresas. Para estudar a colaboração na IMA, foram pesquisados na literatura alguns modelos teóricos, tais como os de Das e Teng (2000), Barczak e Wilemon (2001), Hyväri (2006), Heinz et al (2006), Barnes, Pashby e Gibbons (2006), Emden, Calantone e Droge (2006). Tendo analisado esses modelos, apresentam-se dois problemas: os modelos foram criados a partir de experiências de empresas internacionais e de setores diferentes ao da IMA; os próprios autores reconhecem, ao final de seus trabalhos, que tais listas de FCS não são suficientes e que há necessidade de estudos que expandam para outros setores e locais. Portanto, é necessário elaborar ou adaptar um modelo mais específico e que contenha FCS para os projetos colaborativos de desenvolvimento de produtos em empresas de máquinas agrícolas nacionais. Para este trabalho inicial, procurou-se aplicar uma pesquisa mais qualitativa que permitisse a identificação dos detalhes. Optou-se pelo estudo de caso único e incorporado. A pesquisa teve por objetivo geral a identificação e a elaboração de uma lista de FCS em projetos colaborativos de DP e que possa ser empregado em levantamentos posteriores na 
IMA do interior do Estado de São Paulo. Os objetivos específicos da pesquisa são: identificar na literatura quais os FCS em projetos colaborativos de DP; identificar uma empresa da IMA, com nível elevado de maturidade em DP e que possua projetos de novos produtos, de sucesso e onde haja a colaboração com diferentes organizações externas; demonstrar as características da empresa e a motivação para colaborar nestes projetos; identificar os FCS encontrados em projetos de desenvolvimento colaborativo, com as demais organizações, e compará-los com a lista de FCS proposta pela literatura da área, criando uma lista de FCS que possa ser utilizada em um levantamento na IMA. O trabalho é dividido em 8 capítulos. O capítulo 1 descreve uma abordagem do cenário da inovação e colaboração em DP e a justificativa pela escolha da IMA. O capítulo 2 apresenta um panorama sobre a indústria de bens de capital e também uma descrição mais específica do setor de máquinas agrícolas brasileiro, analisando-o pelas inovações em DP. O capítulo 3 traz uma revisão teórica sobre o processo de desenvolvimento de produtos (PDP) e gerenciamento de projetos (GP), abordando também as características, tipologias, vantagens e desvantagens dos projetos colaborativos de DP. O capítulo 4 apresenta um panorama geral sobre os FCS em projetos colaborativos de DP e um modelo teórico com FCS. Em seguida, descreve o gerenciamento de riscos em projetos colaborativos como um FCS, a lista dos FCS utilizados e o modelo teórico da pesquisa. O capítulo 5 traz a metodologia da pesquisa e no capítulo 6 são analisados os resultados da pesquisa de campo. $\mathrm{O}$ capítulo 7 descreve a análise dos FCS do modelo teórico da pesquisa com os FCS encontrados em cada projeto colaborativo e, por fim. o capítulo 8 apresenta as conclusões da pesquisa e as recomendações para a seqüência do trabalho.

No próximo item será analisada a importância da IBK para a economia do Brasil e descritos detalhadamente os aspectos da IMA nacional enfatizando a inovação em produtos. 


\section{INOVAÇÃO E DESENVOLVIMENTO DE PRODUTO NA INDÚSTRIA DE MÁQUINAS AGRÍCOLAS BRASILEIRA}

Este capítulo apresenta as características e evolução da IMA, especialmente em relação à inovação e DP. Inicia com um panorama geral da indústria de bens de capital (IBK), em seguida descreve a IMA em particular. A seção 2.1 apresenta as características da IBK e sua importância no contexto econômico do país; a seção 2.2 mostra a evolução do setor de máquinas agrícolas; a seção 2.3 traz as características gerais do setor de máquinas agrícolas; a seção 2.4 relata a inovação tecnológica nas máquinas agrícolas; a seção 2.5 destaca o PDP na IMA nacional; e a seção 2.6 descreve a colaboração e inovação no Brasil.

\subsection{Importância econômica e características da indústria de bens de capital}

De acordo com Vermulm (2003, p.1), a IBK é importante para a economia do país na medida em que incorpora aumentos de produtividade de outros bens, implicando a ampliação da capacidade da economia, além do fato de que o bem de capital é portador de conhecimento, pois incorpora tecnologia. Para o mesmo autor, uma situação econômica de relativa instabilidade, ao gerar incertezas quanto ao futuro, inibe o mercado de bens de capital. Por outro lado, a estabilidade econômica e a criação de um ambiente favorável ao crescimento são extremamente benéficas para o mercado de bens de capital.

Ainda conforme Vermulm (2003, p.2), a taxa de juros e as expectativas futuras dos negócios são os dois grandes condicionantes do desempenho da IBK para a economia. Segundo esse autor, para um mesmo estado de expectativas, altas taxas de juros dificultam as vendas de bens de capital porque encarecem os preços das máquinas e dos equipamentos, na medida em que, dado o elevado valor dos produtos, a maior parte das vendas nesse mercado é 
realizada através de financiamento. Para o autor, além de afetar a demanda de bens de capital, a taxa de juros inibe os investimentos na própria produção de máquinas e equipamentos.

A IBK fabrica as máquinas e equipamentos utilizados pelos demais setores para produzir bens e serviços e uma das principais características é a heterogeneidade em dois níveis: produtos e de empresas (AVELLAR, 2008).

Vermulm (2003, p. 5) cita as seguintes características em produtos: os bens de capital se diferenciam entre si segundo a finalidade a que se destinam, meios de controle, desempenho e acessórios. Assim, cada tipo de indústria usuária de bem de capital demanda um produto diferente e específico; dessa forma, existem máquinas para embalagens, máquinas e implementos para a agricultura, máquinasferramenta, máquinas para a indústria têxtil etc. Mesmo que as máquinas se destinam a um usuário específico elas se diferenciam pelo tipo de trabalho que realizam, como por exemplo, máquinas para tornear, para retificar, para conformar materiais metálicos. Ainda que seja para uma mesma função, existem tipos de máquinas que se diferenciam pelo desempenho, flexibilidade, produtividade, precisão, preço, sofisticação tecnológica etc. Nesse contexto existem produtos que seguem distintos paradigmas tecnológicos; hoje coexistem máquinas eletromecânicas com as máquinas de comando computadorizado.

Em relação à heterogeneidade de empresas, Vermulm (2003, p.8) argumenta que: de acordo com os produtos, as empresas detêm ativos tangíveis e intangíveis diferenciados. De forma análoga, em relação às barreiras à entrada nos respectivos mercados. Para ser competitiva, toda empresa de bens de capital necessita deter, além de instalações, máquinas e mão-de-obra adequadas, competências específicas em engenharia de projeto e produto, comercialização e serviços de assistência técnica pós-venda. No entanto, a heterogeneidade de produtos e processos existente dentro da indústria de bens de capital implica também que são muito distintos os ativos e rotinas que tornam uma empresa competitiva dentro dos segmentos de mercado em que atua - ou seja, que o peso relativo das competências varia 
substancialmente dentro do mix competitivo. Assim, na produção de bens seriados, economias estáticas de escala são muito mais importantes do que na fabricação por encomenda, onde as economias dinâmicas, resultado da repetição de experiências de projetar e fabricar bens com características semelhantes são cruciais. No primeiro caso, as empresas tendem a operar com maquinário especializado e processos relativamente rígidos, enquanto no segundo a flexibilidade dos equipamentos, da mão-de-obra e das rotinas produtivas é essencial.

De acordo com Avellar (2008), uma outra característica forte da IBK é a importância do aprendizado tecnológico no ato de fazer e desenvolver novos produtos e processos por intermédio de pesquisas internas ou parcerias externas. Segundo a autora, uma das maiores fontes de aprendizado do setor está no ato de adaptar as máquinas e os equipamentos para a produção a que se destinam, sendo essa estratégia muito utilizada pelas empresas produtoras de bens de capitais mecânicos.

Conforme Megliorini (2003), os produtos da IBK podem ser produzidos em série ou por encomenda. Em série possuem maior homogeneidade, pois resultam de projetos para atender a formulações padronizadas de desenhos, já por encomenda, atendem a formulações de desenhos específicos para um determinado processo ou instalação industrial.

Assim como os demais setores de atividade econômica do país, todo o conjunto de atividades e produtos que compõe a IBK recebe uma classificação. Neste trabalho foi utilizada a classificação do Cadastro Nacional de Atividades Econômicas (CNAE) ${ }^{1}$ que classifica as empresas pela atividade econômica e é dividido em: seção, divisão, grupo, classe e subclasse. A IBK representa a seção C - Indústria de Transformação. Especificamente o sub-setor de Máquinas Agrícolas está classificado na divisão 28 - fabricação de máquinas e equipamentos, no grupo 283 - fabricação de tratores e de máquinas e equipamentos para a

\footnotetext{
${ }^{1}$ É a classificação oficialmente adotada pelo Sistema Estatístico Nacional (SEN) na identificação da atividade econômica em cadastros e registros de pessoas jurídicas.
} 
agricultura e pecuária, havendo ainda a separação por classe e por subclasse. A classificação da IBK conforme o CNAE está descrita na figura 1.

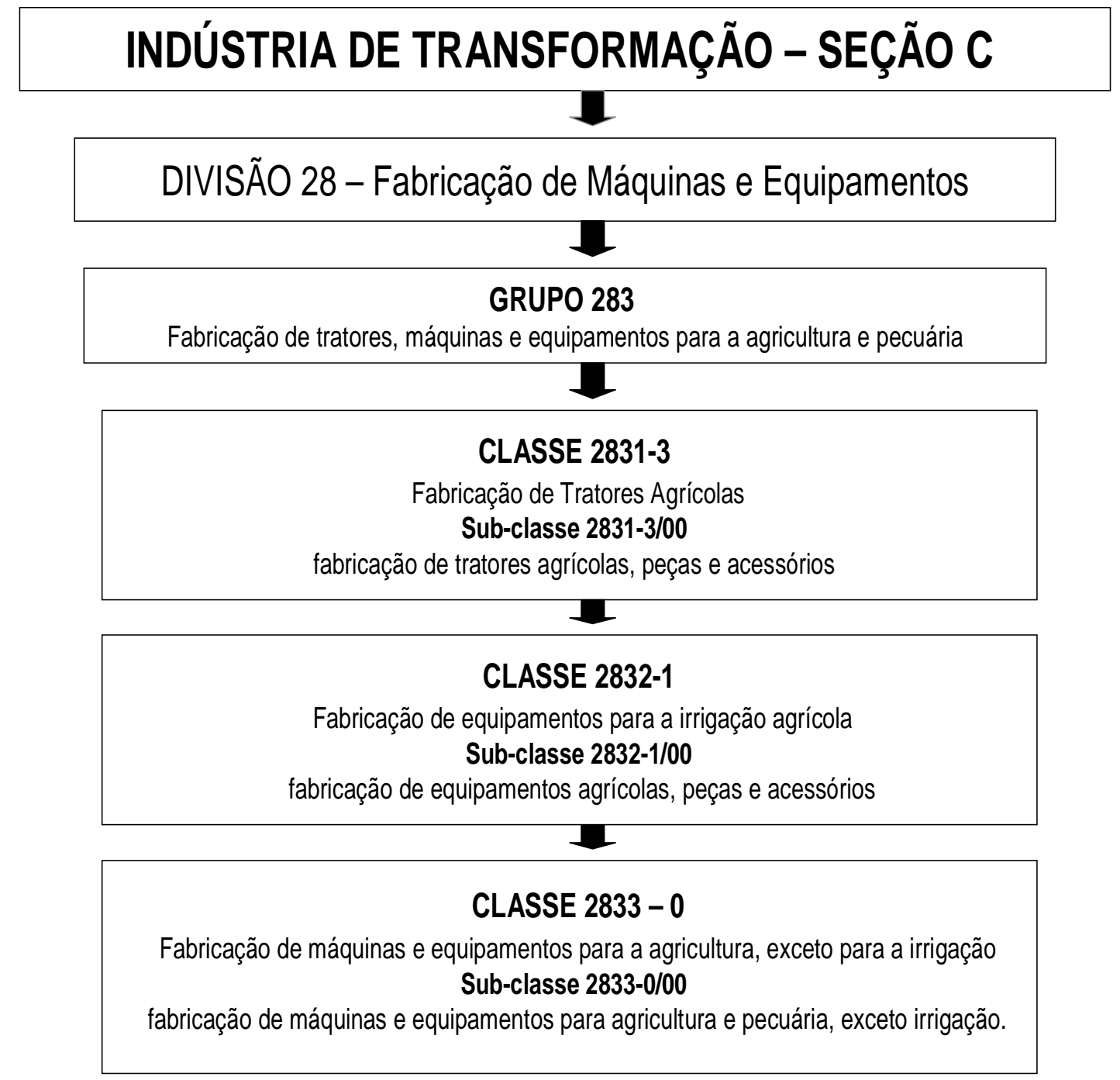

Figura 1. Classificação da IBK conforme a estrutura do CNAE (adaptada pelo autor) Fonte: IBGE (2007b)

De acordo com Avellar (2008), existem outras classificações editadas por organismos nacionais e estrangeiros para a IBK, porém há dificuldades para se fazer um alinhamento entre as bases de dados, principalmente aquelas pertencentes aos organismos estrangeiros com as informações existentes no Brasil. Algumas dessas classificações nacionais e organismos estrangeiros são descritos na seqüência. 
- A Nomenclatura Comum de Mercadorias $(\mathrm{NCM})^{2}$ do Ministério do Desenvolvimento, Indústria e Comércio Exterior (MDIC) está relacionada com às classificações de produtos sendo que a IBK é organizada nos capítulo $84,85,86$ e 87.

- A Associação Brasileira das Indústrias de Máquinas e Equipamentos $(\text { ABIMAQ) })^{3}$ subdivide a IBK em 19 segmentos de acordo com os produtos.

- A International Standard Industrial Classification of All Economic Activities $(I S I C)^{4}$ Rev 3 é uma classificação de atividades econômicas de referência tendo como gestor a Divisão de Estatística das Nações Unidas e tem por finalidade principal estabelecer uma classificação uniforme das atividades econômicas produtivas.

- Nomenclature Générale des Activités Économiques dans lês Communautées Européennes (NACE) Rev $1^{5}$ define a estrutura de todas as nomenclaturas de atividades econômicas na União Européia e tem sido adotada por outros países europeus. É derivada da ISIC Rev 3.

\subsection{A evolução do setor de máquinas agrícolas}

O surgimento deste setor no Brasil se relaciona com a imigração européia nas décadas de 1930 e 1940. Imigrantes, vindos para trabalhar na agricultura e com conhecimentos de mecânica e metalurgia, começaram a produzir artesanalmente as primeiras máquinas e implementos (PASQUAL; PEDROZO, 2007).

\footnotetext{
${ }^{2}$ http://www.mdic.gov.br/sitio/interna/interna.php?area=5\&menu=1095-acesso em 21 de março de 2008

3 http://www.abimaq.org.br.

${ }_{5}^{4} \mathrm{http} / / /$ unstats.un.org/unsd/cr/registry/regcst.asp?Cl=27\&Lg=1-acesso em 21 de março de 2008

${ }^{5} \mathrm{http} / / / \mathrm{www}$. insee.fr/fr/nomenclatures/naf/Pages/naf.htm>=acesso em 21 de março de 2008
} 
Com a implantação da indústria automobilística nos anos de 1960, foram lançados no mercado os primeiros tratores fabricados no Brasil (ANFAVEA, 2006a). Após um período de crescimento na década de 1970, no início dos anos de 1980 o setor apresentou uma retração na capacidade produtiva (RIBEIRO, 2006) em virtude de modificações ocorridas na política de crédito rural (MANO, 2006).

As políticas econômicas e a abertura à concorrência externa no início dos anos de 1990 prejudicaram o desempenho do setor resultando em uma redução dos níveis de produtividade (PASQUAL; PEDROZO, 2007).

Este cenário começou a mudar ao final da década de 1990, quando as empresas passaram a integrar novas tecnologias em produtos e processos (ROMANO, 2003). Em 1999, com a criação do Programa de Modernização da Frota Agrícola (MODERFROTA) ${ }^{6}$, a produtividade do setor apresentou crescimento entre 2000 até 2004, porém fatores como o câmbio, aumento dos insumos e a seca prejudicaram o desempenho em 2005 (ANFAVEA, 2006b).

Em 2007 o segmento de máquinas e implementos agrícolas apresentou recuperação principalmente em função da cultura de grãos e dos negócios relacionados às usinas produtoras dos derivados da cana-de-açúcar (ABIMAQ, 2007).

Já para 2008, os principais fabricantes (CNH, John Deere, Agrale, AGCO) estão estimando um crescimento de $8 \%$ a $10 \%$ nas vendas internas, e uma estabilidade nas exportações. (HUNOFF, 2007).

O gráfico 2 apresenta o desempenho do setor no período compreendido entre os anos de 2000 até 2006 com a produção total, vendas nacionais e as exportações de tratores de rodas, tratores de esteiras, de colheitadeiras e retro escavadeiras em unidades.

\footnotetext{
${ }^{6}$ Programa de crédito do Banco Nacional de Desenvolvimento Econômico e Social (BNDES) com objetivo de modernizar a frota de tratores e colheitadeiras.
} 


\section{Produção e Vendas}

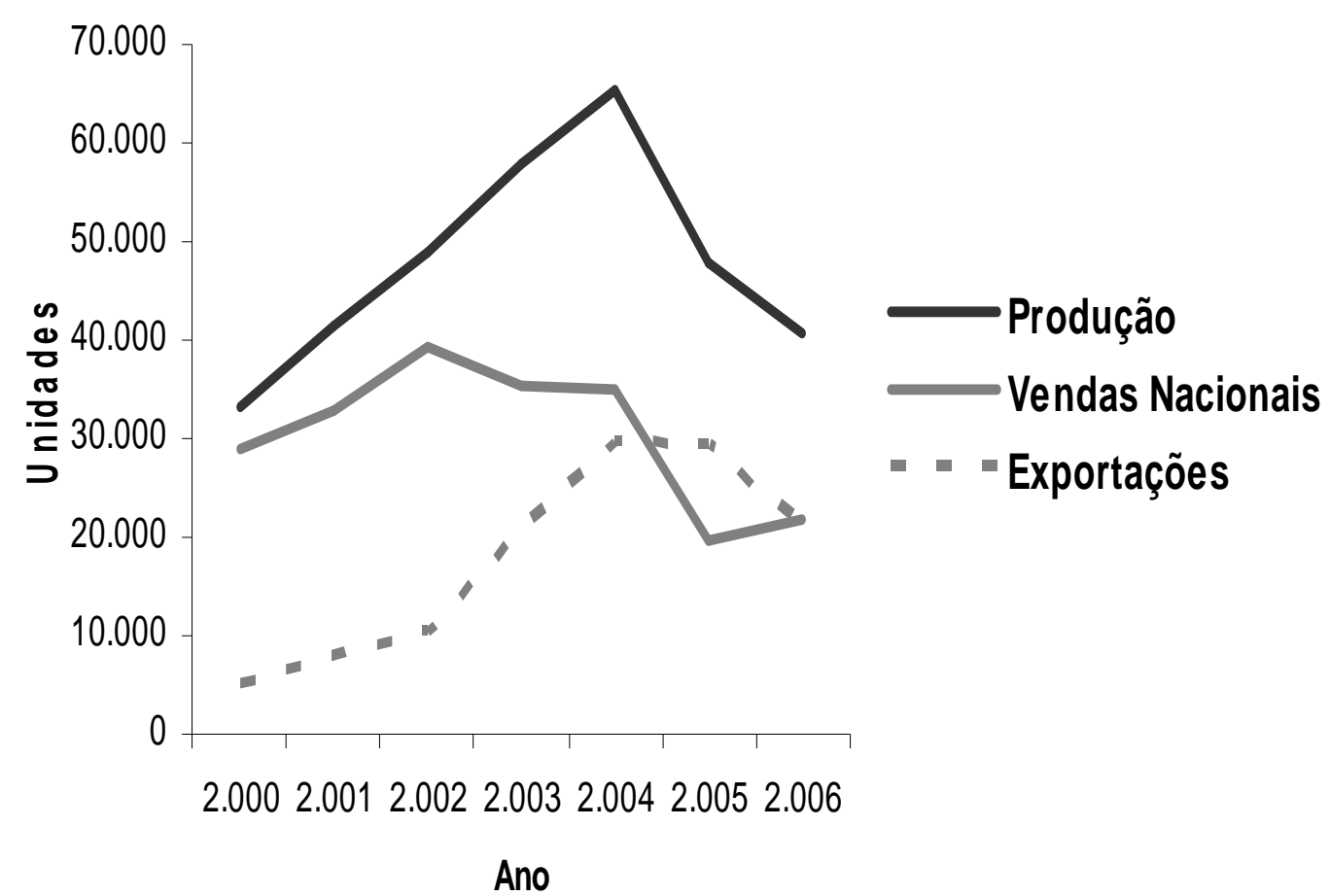

Gráfico 2. Volume de produção e vendas no período 2000 a 2006 Fonte: ANFAVEA, (2006b)

\subsection{Características gerais do setor de máquinas agrícolas}

De acordo com Passos e Calandro $(1999)^{7}$, citados por Ribeiro (2006), este setor é bem segmentado, pois produz desde os implementos mais elementares e manuais até as máquinas agrícolas motorizadas e com recursos tecnológicos agregados.

Conforme dados publicados pela Associação Nacional dos Fabricantes de Veículos Automotores (ANFAVEA, 2006a), as máquinas agrícolas motorizadas compreendem basicamente os tratores de rodas, tratores de esteiras, colheitadeiras e retro escavadeiras e os

\footnotetext{
${ }^{7}$ PASSOS, Maria Cristina; CALANDRO, Maria Lucrecia. Transformações nas estratégias de produção da indústria de máquinas e implementos agrícolas do Rio Grande do Sul. In: Documentos FEE: Impactos Sociais e Territoriais da Reestruturação Econômica no Rio Grande do Sul. Porto Alegre:SECPLAN/RS - FEE: Siegfried Emanuel Heuser, 1999.
} 
maiores fabricantes em termos de faturamento são: AGCO, AGRALE, Caterpillar, CNH, John Deere, Komatsu e Valtra (Quadro 1).

\begin{tabular}{|l|l|c|}
\hline \multicolumn{1}{|c|}{ Empresas } & \multicolumn{1}{|c|}{ Produtos } & Fábricas \\
\hline AGCO (Massey Ferguson) & Colheitadeiras, Tratores de rodas e Retro escavadeiras & duas \\
\hline AGRALE & Tratores de rodas & uma \\
\hline Caterpillar & Tratores de esteiras & uma \\
\hline & Colheitadeiras, Tratores de esteiras, Tratores de rodas e Retro & duas \\
\hline CNH & escavadeiras & uma \\
\hline John Deere & Colheitadeiras e Tratores de rodas & uma \\
\hline Komatsu & Tratores de esteiras & \multicolumn{1}{|c|}{} \\
\hline Valtra & Tratores de rodas & \multicolumn{1}{|c|}{} \\
\hline
\end{tabular}

Quadro 1. Principais fabricantes de máquinas agrícolas no Brasil Fonte: ANFAVEA (2006a)

Convém esclarecer a diferença para os termos "máquinas" e "implementos". Para Gadanha Jr. et al (1991) as máquinas são conjuntos de componentes com movimentos suficientes para transmitir o efeito de forças ou energia e são motoras quando transformam o efeito e movidas quando transmitem o efeito. Os implementos são conjuntos de componentes que não transformam energia. Gadanha Jr. et al (1991) classificam as máquinas por tipos de atividades a qual se destinam:

- tipo 1: tratores e motores;

- tipo 2: preparo do solo;

- tipo 3: semeadura, plantio e adubação;

- tipo 4: cultivo;

- tipo 5: aplicação de defensivos agrícolas;

- tipo 6: colheita de produtos agrícolas;

- tipo 7: transporte, elevação e manuseio dos cultivos colhidos; 
- tipo 8: processamento e armazenamento.

Ainda conforme Gadanha Jr. et al (1991), as máquinas e os implementos agrícolas são classificados de acordo com a fonte de potência de acionamento e podem ser:

- fontes motorizadas: funcionam por meio de motor de combustão interna;

- fontes tratorizadas: utilizam o trator para tração com acionamento ou não dos componentes pela utilização de potência;

- autopropelidas: máquinas que utilizam o mesmo motor para acionar os mecanismos que desempenham as operações básicas de corte, trilha, separação e limpeza;

- tração animal: utiliza como fonte de potência os animais.

Mialhe (1974, p.16) conceitua máquinas e implementos da forma descrita a seguir:

Máquina é o conjunto de órgãos, forçados em seus movimentos por obstáculos fixos e de resistência suficiente para transmitir o efeito de forças e transformar energias. Tanto o motor do trator quanto o arado são considerados máquinas, uma vez que, no primeiro, há transformação de energia e, no segundo, apenas transmissão do efeito de forças.

O Implemento é o conjunto forçado de órgãos que não apresentam movimentos relativos nem têm capacidade para transmitir força, sendo seu único movimento o de deslocamento, normalmente imprimido por uma máquina tratora.

De acordo com Romano (2003), os fabricantes de máquinas agrícolas se especializam em um conjunto definido de produtos, como uma estratégia para evitar os problemas de oscilações da demanda, com exceção dos tratores que estão presentes em todo o processo da atividade agrícola.

Conforme Dall’Agnol, (2001), os fabricantes de máquinas agrícolas concentram unidades nos Estados de Goiás, Minas Gerais, São Paulo, Paraná e Rio Grande do Sul (maior exportador). Conforme o mesmo autor, a maioria dos fabricantes de implementos agrícolas 
são empresas com a administração familiar e que possuem uma linha de produtos bem diversificados.

Outras características que este setor apresenta são citadas por Toledo et al (2006):

- é comum a terceirização da produção de componentes e peças;

- dificuldade para a capacitação de fornecedores;

- há uma predominância de empresas familiares;

- muitas empresas estão em fase de transição de uma gestão familiar para a profissional.

A junção entre empresas deste setor, a partir da década de 1990, fez surgir novas marcas e também um avanço nas inovações tecnológicas (IT) e que estão incorporadas aos produtos e processos sendo decisivas para o aumento da produtividade da lavoura brasileira (SAVANACHI, 2007).

Romano (2006, p. 37) destaca ainda que:

devido ao aumento da complexidade das operações agrícolas, as máquinas passaram a incorporar componentes de maior tecnologia, fabricados, normalmente, por empresas especializadas, implicando em inovações nos produtos. Isso faz com que a IMA seja formada em grande parte por empresas montadoras, que compram aproximadamente $60 \%$ dos componentes utilizados na montagem de produtos. A cadeia produtiva integra fabricantes de insumos (siderurgia, metalurgia), de máquinas industriais e de peças e componentes.

\subsection{A inovação tecnológica no setor de máquinas agrícolas}

Para Ribeiro (2006), a competitividade deste setor exige das empresas constantes atualizações nas características tecnológicas de produtos e aprimoramento dos processos produtivos, como forma de se manter no mercado. 
O conceito de "inovação tecnológica" deriva das idéias de Joseph Alois Schumpeter ${ }^{8}$. Para ele o processo inovativo é formado pela invenção, inovação e difusão. Sendo a inovação um processo essencialmente econômico, em que ocorre a comercialização de um novo produto ou a implementação de um novo processo (SCHUMPETER, 1988). A definição Schumpeteriana descreve duas formas para a inovação:

- a empresa pode inovar investindo em equipamentos para novos processos,

- a empresa pode inovar comercializando novos produtos e implementando novos equipamentos de processo que ela própria tenha desenvolvido.

Conforme a Organização para Cooperação de Desenvolvimento Econômico (OCDE, 2005), a inovação tecnológica é dividida em duas categorias: produtos e processos. Sendo que as inovações de produtos podem ser subdivididas em: produtos tecnologicamente novos e produtos aprimorados. As definições da OCDE são exemplificadas a seguir:

- Produto tecnologicamente novo: é um produto cujas características tecnológicas ou usos pretendidos diferem daqueles produtos produzidos anteriormente. Tais inovações podem envolver tecnologias radicalmente novas, podem se basear na combinação de tecnologias existentes sem novos usos, ou podem ser derivadas do uso de novo conhecimento.

- Produto tecnologicamente aprimorado: é um produto existente cujo desempenho tenha sido significativamente aprimorado ou elevado. Um produto simples pode ser aprimorado (em termos de melhor desempenho ou menor custo) através de componentes ou materiais de desempenho melhor, ou um produto complexo que consista em vários subsistemas técnicos

\footnotetext{
${ }^{8}$ 1883-1950-Economista e professor, autor de "A teoria do desenvolvimento econômico" e de "O processo da destruição criadora"
} 
integrados pode ser aprimorado através de modificações parciais em um dos subsistemas.

- Inovacão tecnológica em processos: é a adoção de métodos de produção novos ou significativamente melhorados, incluindo métodos de entrega dos produtos. Tais métodos podem envolver mudanças no equipamento ou na organização da produção, ou uma combinação dessas mudanças, e pode derivar do uso de novo conhecimento. Os métodos podem ter como meta produzir ou entregar produtos tecnologicamente novos ou aprimorados que não são produzidos ou entregues com os métodos convencionais de produção ou pretender aumentar a produção ou eficiência na entrega de produtos existentes.

No setor de máquinas e implementos agrícolas, o aporte tecnológico trouxe competitividade em vários segmentos da produção como as máquinas semeadoras, adubadoras, pulverizadoras, tratores e colheitadeiras (SAVANACHI, 2007).

As razões deste avanço na tecnologia agregada, como maior potência e capacidade, são justificadas também pelo crescimento da produção em diferentes características geográficas do Brasil, como o clima e o solo (REVISTA FARM FÓRUM, 2007).

Outros recursos desenvolvidos são os dispositivos que possibilitam a orientação por satélites, sistemas de piloto automático e a eletrônica embarcada (SAVANACHI, 2007).

Na orientação por satélites, tratores conduzem o plantio por linhas exatas, com mais rapidez e também com mínima margem de erro, dando origem à agricultura de precisão (MARTINEZ, 2007).

De acordo com Clarck e McGuckin (1996), a agricultura de precisão envolve sistemas automáticos compostos por: micro controladores, sensores e atuadores acoplados ao 
equipamento agrícola e interligados ao Sistema de Posicionamento Global (SPG). Molin 9 citado por Cerri (2005) enfatiza que a agricultura de precisão é um elenco de tecnologias e procedimentos para que as lavouras e os sistemas de produção sejam otimizados.

Para Martini et al (2006), a agricultura de precisão permite gerar mapas das áreas produtivas com informações valiosas para um melhor gerenciamento metro a metro do talhão $^{10}$ visando à redução de custos. Capelli (2008) argumenta que as vantagens estabelecidas pela agricultura de precisão são:

- possibilitar o melhor conhecimento do campo de produção, permitindo, desta forma, melhores decisões. O resultado são maior capacidade e flexibilidade para a distribuição dos insumos naqueles locais e no tempo em que são necessários, minimizando os custos de produção;

- oferecer uniformidade na produtividade pela correção dos fatores que contribuem para sua variabilidade obtendo-se, com isto, um aumento global da produtividade;

- proporcionar a aplicação localizada dos insumos necessários para sustentar uma alta produtividade e que contribuem com a preservação do meio ambiente, já que estes insumos são aplicados somente nos locais, quantidades e no tempo necessário.

Os sistemas de piloto automático garantem o paralelismo de atividades na lavoura, principalmente nas atividades de sulcagem e colheita da cana (SAVANACHI, 2007).

\footnotetext{
${ }^{9}$ MOLIN, J.P. Agricultura de precisão: o gerenciamento da variabilidade. Piracicaba: O Autor, 2001.

${ }^{10} \mathrm{sm}$ (de talhar) Terreno cultivado ou próprio para cultura, entre dois regos
} 
Para Savanachi (2007), a eletrônica embarcada é constituída por computadores de bordo instalados nas cabines e que armazenam uma grande quantidade de dados permitindo aos proprietários elaborar um programa de manutenção das máquinas. Destacam-se:

- rotações do motor;

- gasto de combustível;

- tempo que o motor ficou ligado;

- percurso percorrido.

Além do aumento da eficiência, a inovação tecnológica das máquinas agrícolas brasileiras também acompanha a tendência de substituir os combustíveis fósseis ${ }^{11}$ por biocombustíveis $^{12}$, com o objetivo de reduzir as emissões de gases poluentes (TORRICO, 2007).

\subsection{O Processo de desenvolvimento de produtos no setor de máquinas agrícolas}

Uma pesquisa realizada por Toledo et al (2006) teve por objetivo caracterizar o PDP de empresas de pequeno e médio porte da IMA localizadas no interior do Estado de São Paulo. O resultado deste trabalho mostrou que:

- o PDP dessas empresas é focado em atividades que visam principalmente aos aspectos técnicos do produto. Há um desconhecimento por parte dessas empresas em relação às ferramentas gerenciais de apoio ao PDP; não é estabelecido o uso de indicadores de desempenho do projeto e do PDP; não

\footnotetext{
11 Os combustíveis fósseis são resultado do processo de decomposição de plantas e de animais que leva milhares de anos e, por este motivo, não são renováveis. O carvão mineral, os derivados do petróleo (tais como a gasolina, óleo diesel, óleo combustível, o GLP - ou gás de cozinha -, entre outros) e ainda, o gás natural, são os combustíveis fósseis mais utilizados e mais conhecidos.

${ }^{12}$ Os biocombustíveis são fontes de energias renováveis, derivados de produtos agrícolas como a cana-de-açúcar, plantas oleaginosas, biomassa florestal e outras fontes de matéria orgânica.
} 
acontecem reuniões formais de avaliação das atividades realizadas ao longo do PDP; não são feitos registros formais das experiências anteriores dos projetos de DP;

- as atividades da fase de pré-desenvolvimento (informações de mercado e tecnologia, por exemplo) de modo geral são realizadas informalmente;

- em relação às atividades do PDP executadas formalmente pelas empresas, seguindo procedimentos e gerando registros, são da macro fase de desenvolvimento e tais atividades compreendem: as estimativas de orçamento do projeto, definição dos requisitos dos produtos, definição do conjunto de sistemas, subsistemas e componentes do produto, elaboração de protótipos, realização de testes com protótipos, desenvolvimento de ferramentas e gabaritos, desenvolvimento do processo de fabricação, lançamento do produto no mercado;

- algumas atividades do PDP (definição de indicadores de desempenho do projeto, produção de lote piloto, homologação do produto, retirada planejada do produto no mercado) não são realizadas por um número considerável de empresas.

Os resultados da pesquisa realizada por Toledo et al (2006) vêm ao encontro das considerações de Romano (2003), quando este afirma que o PDP, em grande parte das empresas que compõe a IMA, é feito quase que por completo de uma maneira informal de modo que as empresas não adotam e não utilizam procedimentos sistemáticos, sendo fácil encontrar exemplos onde esse processo é realizado apenas de acordo com a experiência dos responsáveis. 
Romano (2003) afirma que mesmo as empresas que executam o processo com um determinado grau de formalidade apresentam deficiências, principalmente nas fases que envolvem o processo do projeto do produto, falta de aplicação de conhecimentos da engenharia simultânea e metodologias de projeto.

No setor de máquinas agrícolas, com algumas exceções, o PDP é orientado para adaptar conceitos existentes às necessidades do mercado, resultando em produtos muitas vezes similares e com pouco conteúdo de inovação tecnológica (ROMANO et al. 2005).

Um trabalho significativo em relação ao PDP é o apresentado por Simões (2007). A pesquisadora realizou um levantamento detalhado em nível de maturidade de desenvolvimento de produtos nas empresas de máquinas agrícolas do Estado de São Paulo.

A primeira conclusão foi a de que todas as empresas se encontravam em um nível de maturidade básico, segundo o modelo de Rozenfeld et al (2006), isto é, realizam a maioria das atividades de maneira informal, confirmando dados de Romano (2003) e Toledo et al (2006). Elas utilizam ferramentas tais como CAD (computer-aided design) e controle de configuração.

A pesquisadora conseguiu identificar também, por meio de uma análise de clusters, três grupos distintos em termos de evolução do processo de desenvolvimento de produto. As características de cada grupo foram resumidas pela autora e são apresentadas na Tabela 2. As empresas do grupo I são as que possuem o menor nível de maturidade. Com poucos métodos implementados e utilização basicamente do CAD como instrumento para desenvolvimento de produtos, algumas nem mesmo chegam a utilizar essa tecnologia. Foi classificada pela autora como estando no nível 1.1 do modelo de maturidade de Rozenfeld et al (2006).

O grupo III é formado pelas empresas de maior nível de maturidade em PDP. Além do CAD, possuem ações formalizadas para testes (realizam lotes pilotos), aplicam o conceito 
de transição de fases, realizam registro de lições aprendidas. Mas, são também incipientes em outras áreas como a dos indicadores de desempenho.

As empresas do grupo II estão em uma fase de transição entre as do grupo I e III. Uma análise na Tabela 2 fornece uma boa idéia do perfil das empresas de cada grupo. 


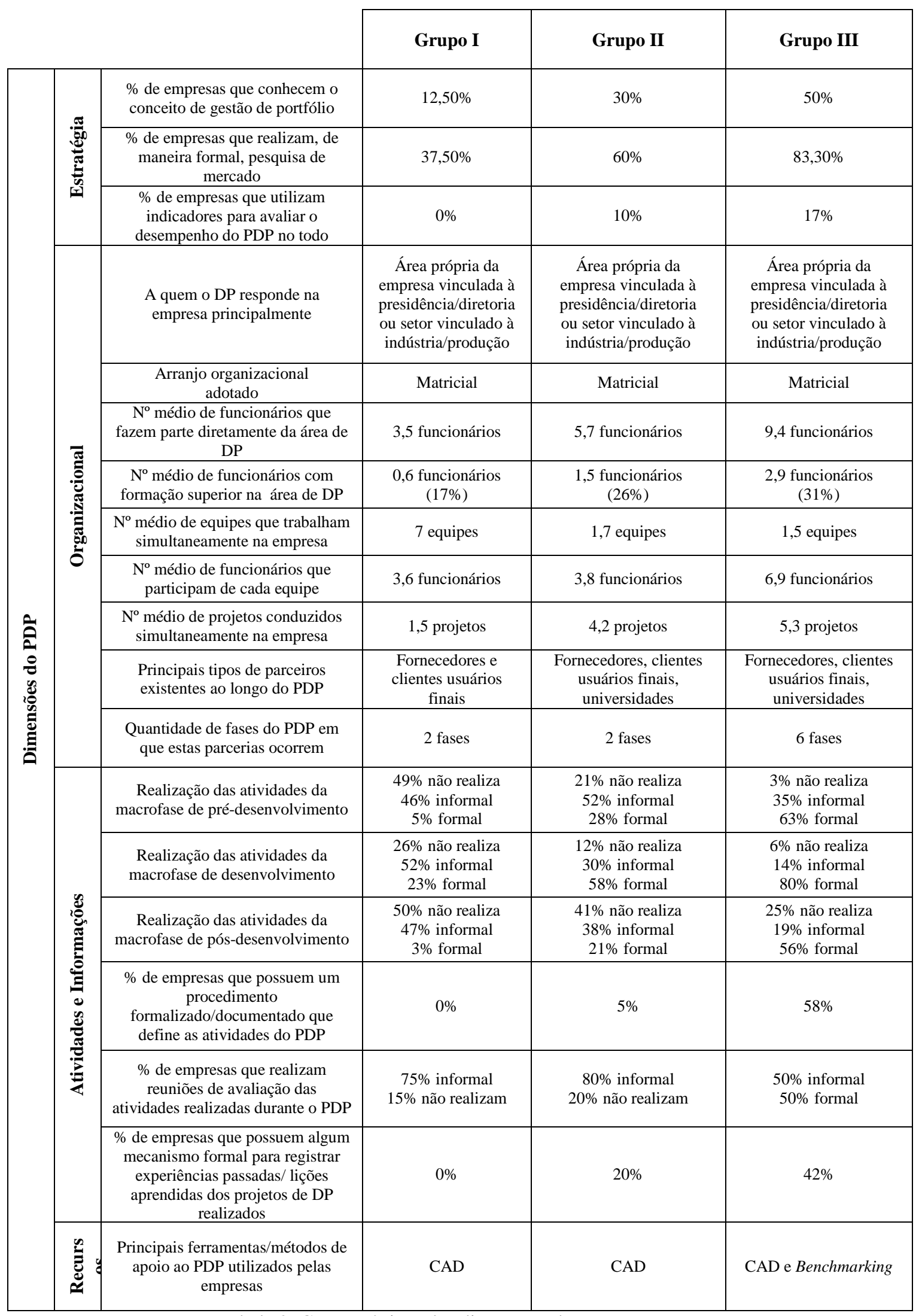

Tabela 2. Características das dimensões do PDP por grupo

Fonte: Simões (2007, p. 117) 


\subsection{Colaboração e inovação no Brasil}

No Brasil, há um número limitado de fontes que disponibilizam informações com embasamento científico para os temas "colaboração" e "inovação". Para este trabalho, foram pesquisadas as principais revistas nacionais. São elas: a Revista de Administração de Empresas (RAE), a Revista de Administração (RA), Revista Gestão e Produção da Universidade Federal de São Carlos (UFSCar), a Revista Produção da Associação Brasileira de Engenharia de Produção (ABEPRO), a Revista Brasileira de Inovação (RBI), a Revista Product: Management and Development e a Pesquisa de Inovação Tecnológica (PINTEC) conduzida e publicada pelo Instituto Brasileiro de Geografia e Estatística (IBGE). A PINTEC $^{13}$ engloba vários assuntos e um deles trata da colaboração e a inovação em pesquisa e desenvolvimento de produtos. A colaboração é definida como a participação de uma empresa em projetos conjuntos de pesquisa, desenvolvimento e inovação com outra organização (IBGE, 2007a). A definição não implica, necessariamente, que as partes envolvidas obtenham benefícios comerciais imediatos. A colaboração entre as empresas e outras organizações é demonstrada na tabela 3 que descreve o total de empresas que foram pesquisadas nas três versões da PINTEC; as empresas que inovaram em pesquisas e desenvolvimento sem a colaboração com outras organizações; as empresas que inovaram em pesquisas e desenvolvimento com a colaboração de outras organizações. Pela tabela, pode ser observado que, desde a primeira versão publicada da pesquisa - correspondente ao triênio 1998 a 2000 - até a mais recente - correspondente ao período de 2003 a 2005 -, houve um acréscimo no número de empresas pesquisadas, da ordem de $26,0 \%$, passando de 72.000 empresas para 91.000 empresas.

\footnotetext{
${ }^{13}$ Publicação trienal: 1998/2000, 2001/2003, 2003/2005.
} 


\begin{tabular}{|c|c|c|c|}
\hline Discriminação & 1998-2000 & $2001-2003$ & $2003-2005$ \\
\hline $\begin{array}{c}\text { Total de empresas } \\
\text { pesquisadas - Brasil }\end{array}$ & 72.000 & 84.300 & 91.000 \\
\hline $\begin{array}{l}\text { Empresas que inovaram } \\
\text { em pesquisa e } \\
\text { desenvolvimento e outros } \\
\text { projetos de inovação sem } \\
\text { colaboração de outras } \\
\text { organizações. }\end{array}$ & $\begin{array}{c}23.000 \\
(32,0 \% \text { em relação ao } \\
\text { total de empresas } \\
\text { pesquisadas })\end{array}$ & $\begin{array}{c}28.000 \\
(33,2 \% \text { em } \\
\text { relação ao total } \\
\text { de empresas } \\
\text { pesquisadas) }\end{array}$ & $\begin{array}{c}30.400 \\
(33,4 \% \text { em relação ao } \\
\text { total de empresas } \\
\text { pesquisadas })\end{array}$ \\
\hline $\begin{array}{l}\text { Empresas que inovaram } \\
\text { em pesquisa e } \\
\text { desenvolvimento e outros } \\
\text { projetos de inovação com } \\
\text { a colaboração de outras } \\
\text { organizações. }\end{array}$ & $\begin{array}{c}2.500 \\
(11,0 \% \text { em relação às } \\
\text { empresas que } \\
\text { inovaram sem } \\
\text { colaboração })\end{array}$ & $\begin{array}{l}1.000 \\
(3,5 \% \text { em } \\
\text { relação às } \\
\text { empresas que } \\
\text { inovaram sem } \\
\text { colaboração) }\end{array}$ & $\begin{array}{c}2.200 \\
(7,0 \text { \% em relação às } \\
\text { empresas que } \\
\text { inovaram sem } \\
\text { colaboração) }\end{array}$ \\
\hline
\end{tabular}

Tabela 3. Relação da colaboração para a inovação

Fonte: IBGE (2007a)

A tabela descreve o número total das empresas pesquisadas e que inovaram em pesquisa e desenvolvimento e outros projetos de inovação sem a colaboração de outras organizações em relação ao total das empresas pesquisadas. São 23.000 empresas no triênio 1998/2000, 28.000 no triênio 2001/2003 e 30.400 no triênio 2003/2005 e que representam $32,0 \%, 33,2 \%$ e $33,4 \%$ do total de empresas pesquisadas, respectivamente. Em termos percentuais, este item apresentou uma evolução de 1,2\% no número dessas empresas entre os triênios de 2001/2003 comparado ao triênio 1998/2000, porém há uma estabilidade em termos percentuais entre os triênios 2003/2005 e 2001/2003, com uma variação de 0,2\% de um triênio ao outro. Uma outra informação da tabela descreve as empresas que inovaram em pesquisa e desenvolvimento e demais projetos de inovação com a colaboração de outras organizações. Foram 2.500 empresas no triênio 1998/2000, 1.000 empresas no triênio 2001/2003 e 2.200 empresas no triênio 2003/2005. Juntas, representam respectivamente onze $(11)$, três e meio $(3,5)$ e sete $(7)$ por cento $(\%)$ em relação às empresas que inovaram sem a colaboração. As principais razões apontadas pelas empresas pesquisadas e que dificultaram o 
desenvolvimento de mais projetos em colaboração com outras organizações foram respectivamente:

- o ambiente macroeconômico do país;

- escassez de fontes de financiamentos;

- falta de pessoas qualificadas e de informações sobre tecnologias;

- resistência organizacional;

- riscos econômicos excessivos.

Esta informação é relevante, pois em uma primeira análise, pode-se sugerir que o país está na contramão da tendência representada pela inovação aberta (Open Innovation) ${ }^{14}$. Porém, de acordo com informações descritas na pesquisa, as empresas que unem inovação com colaboração apresentam o perfil mais diferenciado em termos de desempenho:

- possuem maior faturamento;

- são as que mais exportam;

- faixas salariais acima da média do mercado;

- baixa rotatividade de funcionários;

- maior nível de escolaridade;

- possuem considerável número de patentes e certificações.

Essas são empresas com melhor desempenho gerencial e que utilizam adequadamente seus recursos. Do ponto de vista da gestão do desenvolvimento de produtos e tecnologia, é importante compreender melhor este cenário e entender os FCS nestas colaborações é um dos aspectos.

As empresas que inovaram em pesquisa e desenvolvimento e outros projetos de inovação com a colaboração de outras organizações apontaram como seus parceiros

\footnotetext{
${ }^{14} \mathrm{O}$ conceito de "Open Innovation" se baseia na utilização de fluxos internos ou externos de informações para avançar no desenvolvimento de novas tecnologias
} 
respectivamente: os fornecedores, os clientes, as universidades, institutos de pesquisas, empresas coligadas, centros de capacitação profissional e assistência técnica, empresas de consultoria e concorrentes.

O gráfico 3 mostra quanto representa em termos percentuais para as empresas os parceiros de colaboração.

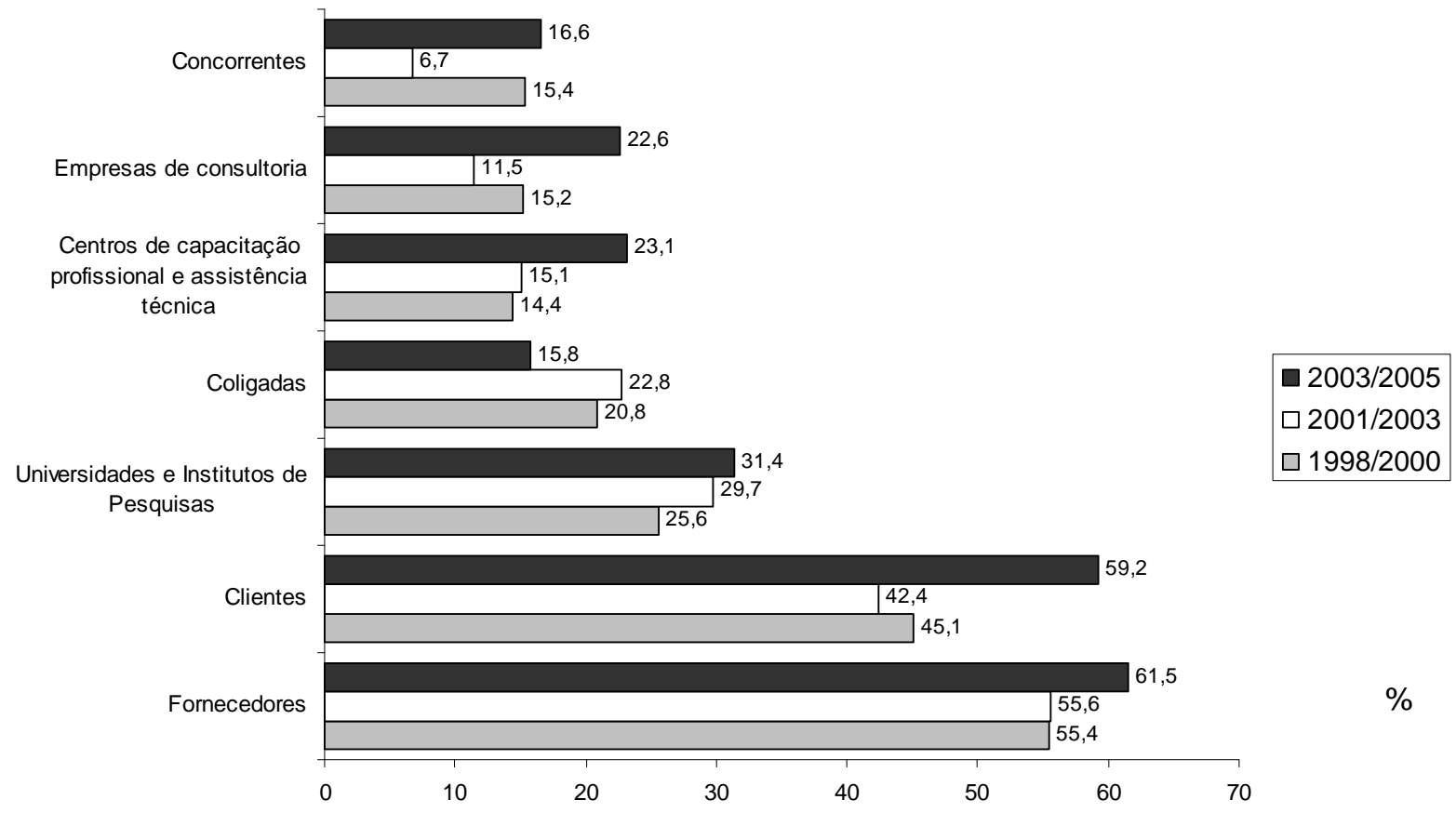

Gráfico 3. Parceiros nas relações de colaboração com a indústria Fonte: IBGE (2007a)

Para esse mesmo grupo de empresas, as decisões para a colaboração geram expectativas de: melhor qualidade nos produtos, ampliação da gama de produtos ofertados, aumento da flexibilidade e capacidade de produção, manutenção da participação da empresa no mercado, abertura de novos mercados, reduções de custos de produção. A edição 2 da PINTEC (triênio 2001/2003) identificou também um outro dado importante: qual era o objeto da colaboração estabelecido com cada um dos parceiros que a empresa manteve a articulação colaborativa. A partir das informações contidas no gráfico 4, é possível observar, em primeiro lugar, que os objetivos da colaboração foram constituídos, sobretudo para a realização de 
projetos de pesquisa e desenvolvimento de produtos. Com esse objetivo, destacam-se as parcerias com fornecedores $(41,3 \%)$, clientes ou consumidores $(36,2 \%)$, universidades e institutos de pesquisa (34,2\%). As outras atividades - assistência técnica, treinamento, desenho industrial - são mencionadas com maior freqüência nas parcerias com centros de capacitação profissional e assistência técnica, como esperado, e com empresas de consultorias, realizando, principalmente, suporte técnico, treinamento e desenho industrial.

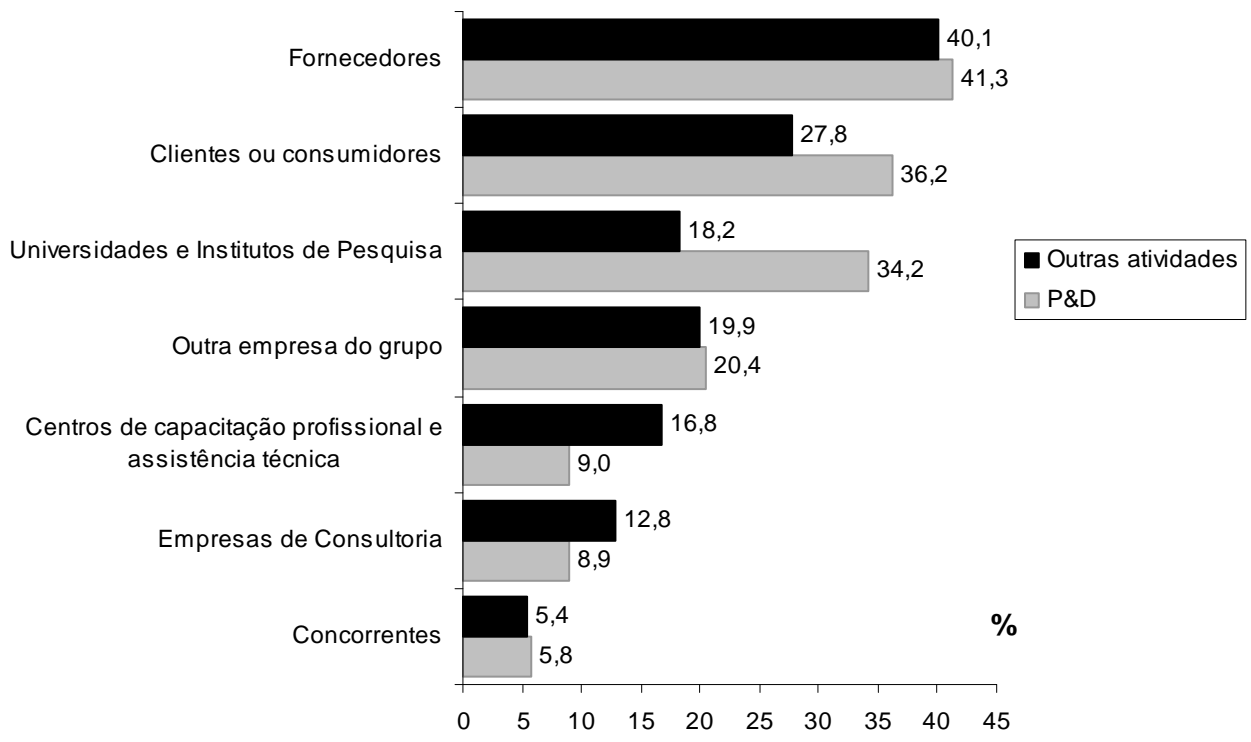

Gráfico 4. Objetivos da colaboração (triênio 2001 - 2003)

Fonte: IBGE (2005)

Este capítulo apresentou um cenário atual sobre a colaboração e a inovação no Brasil. De acordo com os dados apresentados na PINTEC, esta estratégia ainda é pouco explorada pelas empresas. Aquelas que mais rapidamente fizerem uso disso, certamente alcançarão resultados mais expressivos. O próximo capítulo apresenta uma revisão teórica sobre o PDP e introduz ao tema o gerenciamento de projetos colaborativos de DP. 


\section{A COLABORAÇÃO NO DESENVOLVIMENTO DE PRODUTOS}

Este capítulo traz a revisão teórica sobre a colaboração no desenvolvimento de produtos. A seção 3.1 descreve o crescimento da importância do processo de desenvolvimento de produtos (PDP); a seção 3.2 mostra o papel da colaboração no desenvolvimento de novos produtos; a seção 3.3. descreve o gerenciamento de projetos colaborativos e divide-se na subseção 3.3.1. que apresenta o gerenciamento de projetos; a subseção 3.3.2. descreve as características e a tipologia de projetos colaborativos; e a seção 3.4. cita as vantagens e as dificuldades nos projetos colaborativos.

\subsection{O processo de desenvolvimento de produtos (PDP)}

Há alguns anos, o desenvolvimento de produtos era considerado como o conjunto de atividades que dizia respeito apenas às áreas tecnológicas, em especial funções conhecidas como engenharia e protótipo. Hoje está inserido no contexto estratégico, sendo um processo crítico para a competitividade das empresas, em virtude de mudanças constantes em linhas de produtos, redução de custos e prazos de desenvolvimento (TOLEDO et al, 2006).

O PDP pode ser um "elo" entre a empresa e o mercado, cabendo a ele identificar e se antecipar às necessidades do mercado e propor soluções por meio de projetos de produtos (ROZENFELD et al 2006, pg 4) . Para Moura (2002) ${ }^{15}$, citado por Corrêa (2007), o desenvolvimento de produtos está ao lado do planejamento gerencial e da melhoria contínua, uma das três atividades vitais de uma empresa uma vez que o produto que está sendo desenvolvido em um determinado momento determinará o grau de êxito ou fracasso da empresa no futuro.

${ }^{15}$ MOURA, E. C. O desenvolvimento de produtos. Revista Banas Qualidade, Junho de 2002, n.121, p.29. 
Para Clark e Fujimoto (1991), o desenvolvimento de produtos (DP) é o processo que articula as necessidades e oportunidades de mercado, as tecnologias e as competências das empresas, em um horizonte onde os negócios tenham continuidade e competitividade.

Calabrese (1997) afirma que o desenvolvimento de produtos é um processo complexo e que requer controle e interação constantes orientados em trocas de informações entre as pessoas envolvidas com o objetivo de atender às necessidades dos clientes.

Krishnan e Ulrich (2001) definem o PDP como a transformação de uma oportunidade de mercado em um produto disponível para venda por intermédio de um conjunto de atividades. Cooper (2003) considera que o DP é o processo no qual uma empresa utiliza seus recursos e capacidades para criar ou melhorar algum produto existente.

Conforme Chen, Ling e Chen (2003), o PDP é um conjunto de atividades multidisciplinares e que requer informações e contribuições de vários domínios do conhecimento. Esses mesmos autores argumentam que os projetos de novos produtos podem abranger um complexo conjunto de tarefas, as quais envolvem a participação de engenheiros, gerentes, técnicos e outros profissionais por períodos de vários anos.

Womack et al. (1992), Clark e Wheelright (1993), Llori, Oke e Sanni (2000), Parthasarthy e Hammond (2002) entendem que para o DP ser estruturado como um processo, as atividades devem ser feitas por equipes multifuncionais e simultaneamente de acordo com o grau de complexidade e dependência entre elas. Assim o PDP, como um processo bem gerenciado e estruturado, pode facilitar o aumento da capacidade geradora para novos produtos e incremento em novas tecnologias.

Rozenfeld et al (2006) destacam que o PDP tem características específicas quando comparado a outros processos de negócios. Essas características são:

- elevado grau em incertezas e riscos das atividades e resultados; 
- decisões importantes devem ser tomadas n início do processo, quando as incertezas são ainda maiores;

- dificuldade de mudar as decisões iniciais;

- manipulação e geração de alto volume de informações;

- as informações e atividades provêm de diversas fontes internas e externas à empresa;

- multiplicidade de requisitos a serem atendidos pelo processo.

As definições descritas contribuem para um melhor entendimento e importância do PDP. Neste trabalho, é utilizada a conceituação de Rozenfeld et al (2006, p.3), pois recupera e atualiza as citações descritas anteriormente. Esses autores consideram que:

o desenvolvimento de produtos é um conjunto de atividades que busca, a partir das necessidades do mercado e também das possibilidades e restrições tecnológicas, e considerando as estratégias competitivas e de produto de uma empresa, chegar às especificações de projeto de um produto e de seu processo de produção, para que a manufatura seja capaz de produzi-lo. Envolvendo também as atividades de acompanhamento de um produto após o lançamento para, assim, serem realizadas as eventuais mudanças necessárias nessas especificações, planejadas a descontinuidade do produto no mercado e incorporadas as lições aprendidas ao longo do ciclo de vida do produto.

O quadro 2 apresenta as sínteses das interpretações do PDP pelos autores pesquisados por palavras-chave. Pode-se observar que todos fazem alusões aos termos "processos" ou "conjunto de atividades", reforçando a importância do PDP como um processo estratégico dentro das empresas. 


\section{A interpretação do PDP pelos autores pesquisados}

\begin{tabular}{|c|c|}
\hline Autores & palavras-chave \\
\hline Clarck e Fujimoto (1991) & $\begin{array}{c}\text { Processo, oportunidades de mercado, tecnologias e } \\
\text { competências das empresas }\end{array}$ \\
\hline $\begin{array}{c}\text { Womack et al. (1992), Clark e Wheelright (1993), } \\
\text { Llori, Oke e Sanni (2000), Parthasarthy e } \\
\text { Hammond (2002) }\end{array}$ & Processo, equipes multifuncionais, simultaneidade \\
\hline Calabrese (1997) & Processo, controle, interação, troca de informações \\
\hline Krishnan e Ulrich (2001) & $\begin{array}{l}\text { Conjunto de atividades, oportunidade de mercado e } \\
\text { produto }\end{array}$ \\
\hline Moura (2002) & $\begin{array}{c}\text { Conjunto de atividades, planejamento gerencial e } \\
\text { melhoria contínua }\end{array}$ \\
\hline Cooper (2003) & Processos, recursos e capacidades \\
\hline Chen, Ling e Chen (2003), & $\begin{array}{c}\text { Atividades multidisciplinares, equipes } \\
\text { multidisciplinares }\end{array}$ \\
\hline Toledo et al (2006) & Processo crítico, contexto estratégico \\
\hline Rozenfeld et al (2006) & $\begin{array}{c}\text { Atividades, elo de ligação, restrições tecnológicas, } \\
\text { modelo de referência, lições aprendidas }\end{array}$ \\
\hline
\end{tabular}

Quadro 2. A interpretação do PDP

(elaborado pelo autor)

No entendimento de Rozenfeld et al. (2006), o PDP pode ser bem gerenciado com a criação de um modelo de referência que permita uma visão geral do conjunto de atividades, dos recursos, do fluxo de informações e da organização. A definição para modelo de referência utilizada neste trabalho é a descrita por Rozenfeld et al. (2006, p.42):

Um modelo de referência (MR) é um modelo de processo de negócio sendo utilizado com o objetivo de criar modelos específicos e alguns representam as atividades que devem ser realizadas, e outros com mais detalhes, descrevem procedimentos, métodos e critérios de avaliação. O modelo é um documento que pode estar na 
forma de uma publicação, manual, ou mesmo na intranet de uma empresa. Atualmente muitas empresas adotam modelos para orientar o padrão de trabalho desejado em relação ao desenvolvimento de produtos. O MR é um mapa que serve de base para todos e cria um linguajar único na empresa.

Tais modelos passaram de simples descrições do PDP como sistemas lineares que não consideravam importantes as fases seqüenciais (MCCARTHY et al 2006) para modelos contendo regras, diretrizes e procedimentos para o gerenciamento do desenvolvimento de produtos (ENGWALL et al., 2005).

Atualmente esses modelos permitem uma compreensão abrangente do ciclo de vida do produto, bem como o uso e gerenciamento de métodos e técnicas, estabelecendo uma detalhada e integrada percepção do trabalho (ROMANO et al, 2005). Para Rozenfeld et al. (2000), o MR auxilia o gerenciamento do PDP, por facilitar o entendimento e a comunicação entre os participantes do desenvolvimento, e por facilitar a implantação e integração de métodos, técnicas e sistemas de apoio.

Romano (2003) afirma que um modelo de referência tem por objetivos possibilitar:

- uma compreensão mais consistente do processo estudado;

- a aquisição e registro do conhecimento para uso posterior;

- a definição de uma base para o diagnóstico do processo praticado pelas empresas;

- planejar e especificar melhorias no processo diagnosticado nas empresas;

- simular o funcionamento do processo melhorado;

- definir uma base para a tomada de decisões durante o processo;

- racionalizar e garantir o fluxo de informações durante o processo.

Rozenfeld et al (2006) desenvolveram um MR voltado principalmente para as empresas de manufatura de bens de consumo duráveis e de capital (figura 2). 


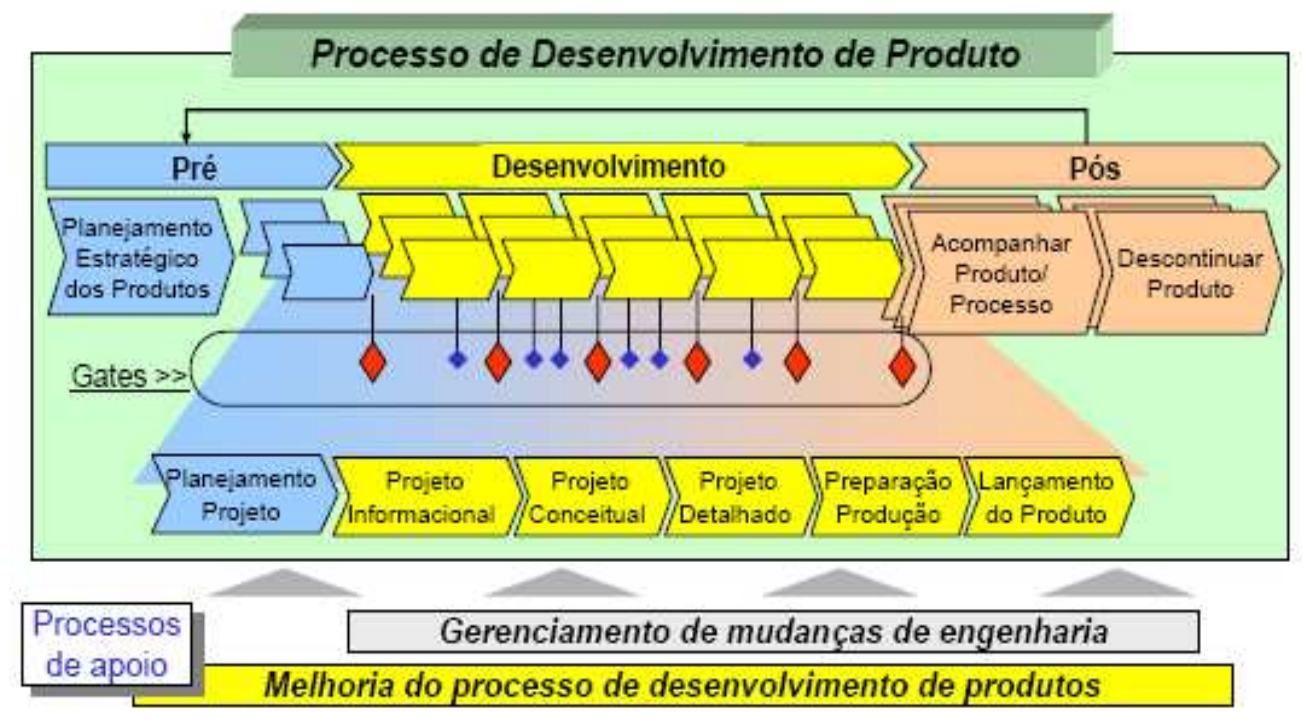

Figura 2. Modelo de referência para o PDP

Fonte: Rozenfeld et al., 2006. pág. 44

Ele é formado por macro fases (pré-desenvolvimento, desenvolvimento e o pósdesenvolvimento) divididas em fases seqüenciais e atividades. As macro fases prédesenvolvimento e pós-desenvolvimento são mais genéricas e podem ser utilizadas em outros tipos de empresa com pequenas alterações. A macro fase de desenvolvimento enfatiza os aspectos tecnológicos correspondentes à definição do produto em si, suas características e formas de produção (ROZENFELD et al, 2006, p. 43). As macro fases que formam o MR possuem as seguintes fases seqüenciais:

- pré-desenvolvimento:

planejamento estratégico de produtos;

planejamento do projeto;

- desenvolvimento:

projeto informacional;

projeto conceitual;

projeto detalhado; 
preparação de produção do produto;

lançamento do produto;

- pós-desenvolvimento:

acompanhar produto e processo;

descontinuar o produto do mercado;

Em cada fase seqüencial são descritas as atividades, os resultados esperados, os responsáveis, os recursos disponíveis, as ferramentas de suporte e as informações necessárias que são geradas no PDP.

Rozenfeld et al (2006) classificam os MR em específicos e genéricos: os específicos são adaptados de um modelo genérico para uma empresa específica enquanto que os genéricos são aplicados a uma determinada área industrial. Como exemplo de área industrial tem-se a IMA. Romano (2003) desenvolveu um MR (figura 3) para a IMA.

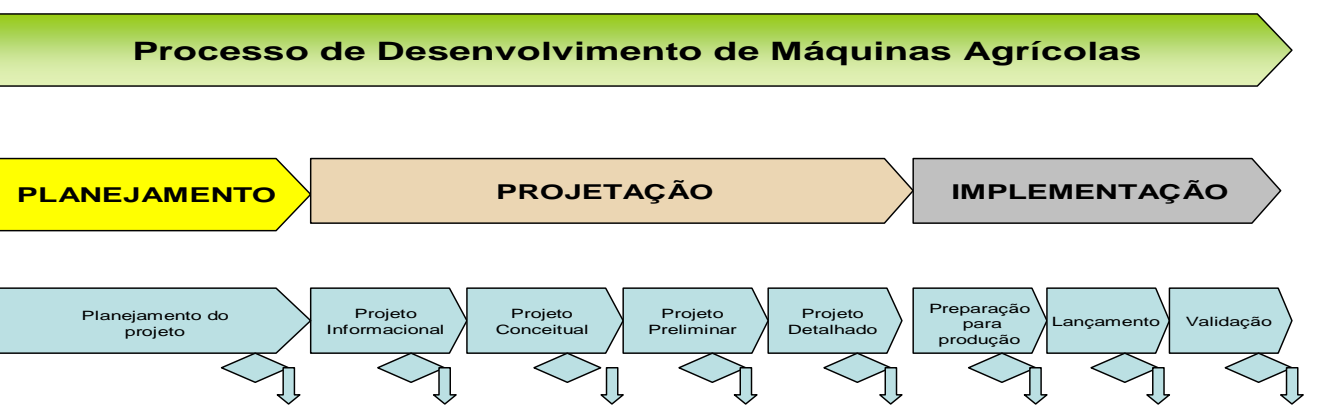

Figura 3. Modelo de referência para a IMA

Fonte: Romano (2003) - (adaptado pelo autor)

O MR desenvolvido por Romano (2003) para a IMA é constituído por três macro fases: 
- planejamento: é referente à elaboração do plano do projeto da máquina agrícola;

- projetacão: envolve a elaboração do projeto do produto e do plano da manufatura. É constituída por quatro fases denominadas, "projeto informacional", "projeto conceitual", "projeto preliminar" e "projeto detalhado". Os resultados principais de cada fase são, respectivamente, as especificações de projeto, a concepção da máquina, a viabilidade econômica e a solicitação do investimento;

- implementacão: envolve a implementação do plano de manufatura na produção da empresa e o encerramento do projeto. É formada por três fases denominadas "preparação da produção", "lançamento" e "validação". Os resultados de cada fase incluem, respectivamente, a liberação do produto, a liberação do lote inicial e a validação do projeto.

\subsection{O papel da colaboração no desenvolvimento de novos produtos}

Fatores como a globalização, inovação tecnológica, competitividade empresarial, mudanças nas demandas dos consumidores, entre outros, contribuem para uma redução no ciclo de vida dos produtos em geral. Este conjunto de variáveis reflete uma reestruturação nas empresas e também exerce pressão no sentido de que se desenvolvam produtos em intervalos de tempo cada vez menores e com qualidade superior para atender às exigências de mercado. A colaboração com agentes externos (clientes, fornecedores, institutos de pesquisas e universidades) para desenvolver novos produtos surge como uma estratégia para superar esse desafio. A colaboração também faz parte das estratégias de empresas que estão mudando a estrutura de pesquisas e desenvolvimento $(\mathrm{P} \& \mathrm{D})$. Ao invés de manter estruturas grandes e 
auto-suficientes em P\&D, elas buscam realizar parcerias com os agentes externos, transferindo parte do esforço para as ações conjuntas. Esta maneira de atuação é destacada por Huston e Sakkab (2006) que descrevem o caso da empresa Procter e Gamble. Segundo os autores, ela possui aproximadamente $45 \%$ de sua extensa linha de produtos sendo desenvolvidos em colaborações com outros agentes ao redor do mundo. Esta estratégia utilizada pela Procter e Gamble é reconhecida como Inovação Aberta (Open Innovation), desenvolvida pelos autores Chesbrough (2003) e Chesbrough e Schwarts (2007). Na visão de Badin (2005), a colaboração no desenvolvimento de produtos (DP) possibilita aos atores integrantes um desempenho econômico e tecnológico melhor além de ganhos de conhecimento. Já para Dong et al (2005), a colaboração permite a realização de trabalhos simultâneos em tarefas independentes. Parung e Bititci (2006) entendem que a colaboração proporciona às empresas um caminho a ser seguido para obter vantagens competitivas de mercado. Para Claro e Oliveira Claro (2004), essas vantagens serão alcançadas somente se todas as questões relacionadas aos projetos elaborados para desenvolver os produtos forem bem gerenciadas, com os objetivos e prazos alinhados, transparência e comprometimento das equipes e capacidade para administrar riscos. O Quadro 3 apresenta uma síntese da interpretação da colaboração no DP na visão dos autores citados nesta seção.

\begin{tabular}{|c|c|}
\hline \multicolumn{2}{|c|}{ Autores citados e suas interpretações sobre a colaboração no DP } \\
\hline Autores & Interpretação \\
\hline Claro e Oliveira e Claro (2004) & $\begin{array}{c}\text { Os objetivos da colaboração precisam estar alinhados } \\
\text { com as técnicas de gerenciamento de projetos para serem } \\
\text { alcançados }\end{array}$ \\
\hline Badin (2005) & Ganhos em conhecimentos (econômico e tecnológico) \\
\hline Dong T. et al (2006) & Permitir trabalhos simultâneos em tarefas independentes \\
\hline Huston e Sakkab (2006) & Permitir parte do esforço para ações conjuntas \\
\hline Parung e Bititci (2006) & Vantagens competitivas de mercado \\
\hline
\end{tabular}

Quadro 3. Síntese da interpretação sobre a colaboração no DP (elaborado pelo autor) 
Para Pigatto e Alcantâra (2006), todas as ações entre os membros integrantes da colaboração precisam ter uma coordenação e alinhamento entre as atividades existentes para que os objetivos possam ser alcançados. E isto faz parte do foco do gerenciamento de projetos (JUCÁ Jr. 2005). A próxima seção descreve o gerenciamento de projetos colaborativos.

\subsection{Gerenciamento de projetos colaborativos}

Esta seção divide-se em duas subseções. A primeira descreve a definição de gerenciamento de projetos e a segunda apresenta a definição de gerenciamento de projetos colaborativos.

\subsubsection{Definição de gerenciamento de projetos}

O gerenciamento de projetos (GP) é um conjunto de técnicas e métodos que apóia as atividades de coordenação, execução e controle dos projetos de forma a obter um controle melhor para tomar decisões estratégicas (BELZER, 2000). Esse conjunto de técnicas e métodos facilita o estabelecimento de metas, o planejamento e organização das tarefas, a definição de responsabilidades, o processamento da informação e tomadas de decisão e a seleção das pessoas envolvidas (SCHNEIDER, 1995).

Para Srivannaboon e Milosevic (2006), o GP é uma forma especializada de gerenciamento, similar a outras estratégias funcionais usadas para acompanhar os objetivos de negócios, estratégias e tarefas dentro de um programa e orçamentos definidos.

Para Heldman (2003), o GP é um processo que exige várias atividades, incluindo planejar, colocar em ação o plano do projeto e acompanhar o progresso e o desempenho.

Chen e Partington (2006) argumentam que o crescimento do GP como disciplina profissional permite estabelecer uma padronização que define o seu escopo, descreve ferramentas, técnicas e conceitos. 
De acordo com Pant e Baroudi (2008), o GP está sendo entendido como uma nova forma de administração geral e que permite às organizações melhorar a integração, o planejamento e o controle de todas as suas atividades, proporcionando assim um desempenho organizacional superior.

Kerzner (1998) e Verzuh (2000) argumentam que o GP converge para a existência de uma sistematização e a organização dos processos de definição, planejamento, execução, controle e conclusão de projetos, aplicando técnicas e métodos para estimar, planejar e controlar atividades com o objetivo de alcançar um resultado final dentro de determinado prazo, custo e de qualidade.

Para Shenhar e Dvir (2007), os projetos são usados não apenas para o desenvolvimento de novos produtos, mas também para a melhoria de produtos existentes, desenvolvimento de softwares, reengenharia de processos, campanhas de marketing e muitas outras atividades empresariais.

Há uma diversidade de publicações que descrevem os benefícios do GP no resultado global de organizações em todos os setores de atividade (LASZLO, 1999; KOLLTVEIT et al, 2007). Institutos e Associações editam publicações e formam conceitos sobre o gerenciamento de projeto, entre os quais:

- Association for Project Management (APM) - Reino Unido

- Australian Institute for Project Management (AIPM) - Austrália

- International Project Management Association (IPMA) - Holanda

- Project Management Institute (PMI) - Estados Unidos.

Este trabalho utiliza os conceitos do PMI sobre o GP. O PMI é a organização de referência mundial em GP e o seu programa de certificação é reconhecido pela International 
Organization for Standardization (ISO) 9001 (HELDMAN, 2003). O PMI edita o Project Management Body of Knowledge (PMBoK), uma guia que descreve os aspectos do GP.

O PMBoK (2004) define projetos como um empreendimento que tem início e fins definidos e com o objetivo de criar um produto ou serviço e o GP como a aplicação de conhecimentos, habilidades, ferramentas e técnicas para planificar e controlar atividades que permitam atingir os requisitos de um projeto.

Segundo esse padrão, os projetos são formados por cinco grupos de processos $^{16}$ onde são organizados e descritos todos os trabalhos que serão elaborados.

Os cinco grupos de processos são assim definidos pelo PMBoK (2004):

- processos de iniciacão: definem e autorizam o projeto ou uma fase do projeto;

- processos de planejamento: definem e refinam os objetivos e planejam a ação necessária para alcançar os objetivos e o escopo para os quais o projeto foi realizado;

- processos de execucão: integram pessoas e outros recursos para realizar o plano de gerenciamento do projeto para o projeto;

- processos de monitoramento e controle: medem e monitoram regularmente o progresso para identificar variações em relação ao plano de gerenciamento do projeto, de forma que possam ser tomadas ações corretivas quando necessárias para atender aos objetivos do projeto;

- processos de encerramento: formalizam a aceitação do produto, serviço ou resultado e conduzem o projeto ou uma fase do projeto a um final ordenado.

De acordo com o PMBoK (2004), o GP deve considerar de forma integrada várias áreas de conhecimentos, tais como: o escopo, tempo, custo, qualidade, recursos humanos, as comunicações do projeto, a gestão de riscos, as compras da empresa e a integração de todas

\footnotetext{
${ }^{16}$ Um processo é um conjunto de ações que geram um resultado (PMBoK, 2004)
} 
essas áreas distribuídas nos cinco grupos de processos. As áreas do conhecimento descritas na seqüência têm definidas as suas funções dentro dos processos de GP:

- integracão do gerenciamento do projeto: é a área que interage e coordena todos os aspectos do plano do projeto. O planejamento, a execução do projeto e o controle de mudanças ocorrem em todo o projeto e se repetem continuamente durante o esforço do projeto;

- gerenciamento do escopo do projeto: essa área do conhecimento diz respeito aos processos do trabalho do projeto;

- gerenciamento de tempo do projeto: essa área abrange a estimativa da duração das atividades do plano do projeto, importando com a conclusão do projeto em tempo hábil;

- gerenciamento do custo do projeto: nessa área do conhecimento são definidas as estimativas dos recursos monetários e o controle desses recursos para garantir que o projeto permaneça dentro do orçamento previsto;

- gerenciamento da qualidade do projeto: essa área deve assegurar que o projeto atenda aos requisitos com os quais se comprometeu. Deve avaliar o desempenho geral, monitorar os resultados do projeto e comparar com os padrões de qualidade estabelecidos no planejamento do projeto;

- gerenciamento dos recursos humanos do projeto: abrange todos os aspectos do gerenciamento e da interação das pessoas, incluindo liderar, treinar, tratar dos conflitos;

- gerenciamento das comunicações do projeto: estão relacionadas às habilidades gerais de comunicação. Essas habilidades tentam garantir que todas as informações do projeto sejam reunidas e documentadas como também 
asseguram a distribuição e compartilhamento das informações com integrantes do projeto;

- gerenciamento do risco do projeto: essa área visa à identificação e planejamento dos possíveis riscos que possam afetar o projeto;

- gerenciamento de compras ou aquisicões do projeto: abrange todas as compras de mercadorias e serviços em fornecedores externos.

Na seqüência, o Quadro 4 mostra o relacionamento entre as áreas de conhecimento e os grupos de processos do GP. 


\begin{tabular}{|c|c|c|c|c|c|}
\hline \multirow{2}{*}{$\begin{array}{c}\text { Áreas de } \\
\text { conhecimento }\end{array}$} & \multicolumn{5}{|c|}{ Grupos de processos de gerenciamentos de projetos } \\
\hline & Iniciação & Planejamento & Execução & $\begin{array}{l}\text { Monitoramento e } \\
\text { Controle }\end{array}$ & Encerramento \\
\hline $\begin{array}{l}\text { Integração do } \\
\text { gerenciamento } \\
\text { do projeto }\end{array}$ & $\begin{array}{c}\text { Desenvolver } \\
\text { o termo de } \\
\text { abertura do } \\
\text { projeto. } \\
\text { Desenvolver } \\
\text { a declaração } \\
\text { de escopo } \\
\text { preliminar do } \\
\text { projeto }\end{array}$ & $\begin{array}{l}\text { Desenvolvimento do } \\
\text { plano de gerenciamento } \\
\text { do projeto }\end{array}$ & $\begin{array}{l}\text { Orientar e } \\
\text { gerenciar a } \\
\text { execução do } \\
\text { projeto }\end{array}$ & $\begin{array}{c}\text { Monitorar e controlar } \\
\text { o trabalho do projeto } \\
\text { Controle integrado de } \\
\text { mudanças }\end{array}$ & $\begin{array}{l}\text { Encerrar o } \\
\text { projeto }\end{array}$ \\
\hline $\begin{array}{l}\text { Gerenciamento } \\
\text { do escopo do } \\
\text { projeto }\end{array}$ & & $\begin{array}{c}\text { Planejamento e } \\
\text { definição do escopo } \\
\text { Criar EAP }\end{array}$ & & $\begin{array}{l}\text { Verificação do escopo } \\
\text { Controle do escopo }\end{array}$ & \\
\hline $\begin{array}{l}\text { Gerenciamento } \\
\text { de tempo do } \\
\text { projeto }\end{array}$ & & $\begin{array}{l}\text { Definição da atividade } \\
\text { Seqüenciamento de } \\
\text { atividade } \\
\text { Estimativas de recursos } \\
\text { da atividade } \\
\text { Estimativa de duração } \\
\text { da atividade } \\
\text { Desenvolvimento do } \\
\text { cronograma }\end{array}$ & & $\begin{array}{l}\text { Controle do } \\
\text { cronograma }\end{array}$ & \\
\hline $\begin{array}{l}\text { Gerenciamento } \\
\text { de custo do } \\
\text { projeto }\end{array}$ & & $\begin{array}{l}\text { Estimativa de custos } \\
\text { Orçamentos }\end{array}$ & & Controle dos custos & \\
\hline $\begin{array}{l}\text { Gerenciamento } \\
\text { da qualidade do } \\
\text { projeto }\end{array}$ & & $\begin{array}{l}\text { Planejamento da } \\
\text { qualidade }\end{array}$ & $\begin{array}{l}\text { Garantia da } \\
\text { qualidade }\end{array}$ & Controle da qualidade & \\
\hline $\begin{array}{c}\text { Gerenciamento } \\
\text { de Recursos } \\
\text { humanos do } \\
\text { projeto }\end{array}$ & & $\begin{array}{l}\text { Planejamento de } \\
\text { recursos humanos }\end{array}$ & $\begin{array}{c}\text { Contratar ou } \\
\text { mobilizar a } \\
\text { equipe do } \\
\text { projeto } \\
\text { Desenvolver a } \\
\text { equipe do } \\
\text { projeto } \\
\end{array}$ & $\begin{array}{l}\text { Gerenciar a equipe do } \\
\text { projeto }\end{array}$ & \\
\hline $\begin{array}{c}\text { Gerenciamento } \\
\text { de } \\
\text { comunicação } \\
\text { do projeto }\end{array}$ & & $\begin{array}{l}\text { Planejamento das } \\
\text { comunicações }\end{array}$ & $\begin{array}{l}\text { Distribuição das } \\
\text { informações }\end{array}$ & $\begin{array}{l}\text { Relato de desempenho } \\
\text { Gerenciar as partes } \\
\text { interessadas }\end{array}$ & \\
\hline $\begin{array}{l}\text { Gerenciamento } \\
\text { de risco do } \\
\text { projeto }\end{array}$ & & $\begin{array}{l}\text { Planejamento do } \\
\text { gerenciamento de riscos } \\
\text { Identificação de riscos } \\
\text { Análise qualitativa de } \\
\text { riscos } \\
\text { Análise quantitativa de } \\
\text { riscos } \\
\text { Planejamento de } \\
\text { respostas a riscos }\end{array}$ & & $\begin{array}{l}\text { Monitoração e } \\
\text { controle dos riscos }\end{array}$ & \\
\hline $\begin{array}{l}\text { Gerenciamento } \\
\text { de compras do } \\
\text { projeto }\end{array}$ & & $\begin{array}{l}\text { Planejar compras e } \\
\text { aquisições } \\
\text { Planejar contratações }\end{array}$ & $\begin{array}{l}\text { Solicitar } \\
\text { respostas de } \\
\text { fornecedores } \\
\text { Selecionar } \\
\text { fornecedores }\end{array}$ & $\begin{array}{l}\text { Administração de } \\
\text { contratos }\end{array}$ & $\begin{array}{c}\text { Encerramentos } \\
\text { dos contratos }\end{array}$ \\
\hline
\end{tabular}

Quadro 4. Áreas de conhecimento e os grupos de processos de gerenciamento de projetos

Fonte: PMBoK (2004) 


\subsubsection{Definição e tipologias de projetos colaborativos}

Wang et al (2002) consideram que os projetos colaborativos ocorrem quando um produto é projetado com o esforço coletivo dos participantes. Para Evaristo e Fenema (1999), esses projetos podem ocorrer em localização única, isto é, os participantes compartilham um espaço de trabalho comum, mesmo se tratando de diferentes agentes, ou em múltiplos locais, isto é, são distribuídos geograficamente (figura 4).

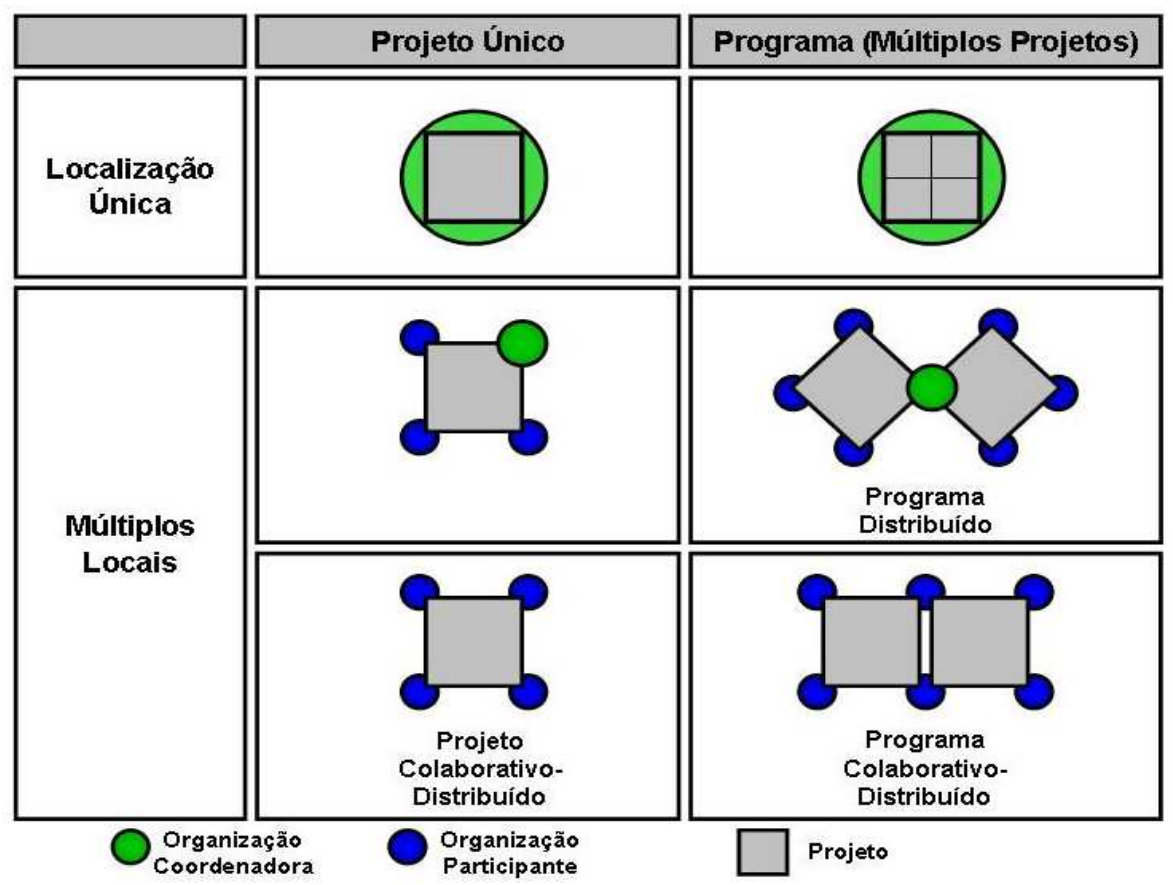

Figura 4. Tipologias de projetos para desenvolvimento de produtos Fonte: Evaristo e Fenema (1999)

Segundo Polzer (2004) e Bejarano et al. (2006), quando esses projetos são realizados em diferentes espaços geográficos e temporais, a interação entre as equipes passa a ser primariamente com a utilização de recursos da tecnologia de informação (TI). Este distanciamento entre as pessoas configura uma "equipe virtual". 
As equipes virtuais, segundo Hertel et al (2005), são formadas por duas ou mais pessoas que agem interativamente para alcançar metas comuns, com ao menos uma delas em tempo, local ou empresa diferentes. Ainda segundo Hertel et al (2005), essa interatividade pode ser feita por intermédio de correio eletrônico, telefone, vídeo conferência, envio de mensagens por fax.

Conforme Finholt (2002), essas equipes podem ser formadas para trabalhar com pesquisa e desenvolvimento de produtos, no atendimento a clientes e em pesquisas científicas entre organizações.

Lipnack e Stamps (1997) descrevem que uma equipe virtual é caracterizada quando um determinado número de pessoas de um grupo interage para atingir objetivos comuns.

O papel que as equipes virtuais podem desempenhar dentro de um projeto colaborativo de DP é importante. Essa importância pode ser entendida como uma redução no tempo e em custos para a realização das tarefas, na aquisição de novos conhecimentos e na realização de vários projetos simultaneamente (NEMIRO, 2001).

Hertel et al (2005) desenvolveram um modelo de gerenciamento de equipes virtuais formado por cinco fases e foi denominado de "Modelo de ciclo de vida para o gerenciamento das equipes virtuais" (figura 5).

As fases do modelo são descritas a seguir:

- planejamento: contém as decisões que são consideradas relevantes quando uma organização está planejando a implementação de uma equipe virtual (definir as metas e os objetivos, selecionar as pessoas e a tecnologia, formas de recompensas);

- início: descreve a integração e as atividades relevantes para o início dos trabalhos das equipes; 
- gerenciamento: inclui a liderança, a comunicação e a motivação das equipes virtuais;

- desenvolvimento: avalia os pontos fortes e os pontos fracos das equipes bem como prepara o treinamento para os novos participantes;

- encerramento: há o reconhecimento dos objetivos atingidos e a reintegração dos membros às atividades de rotina.

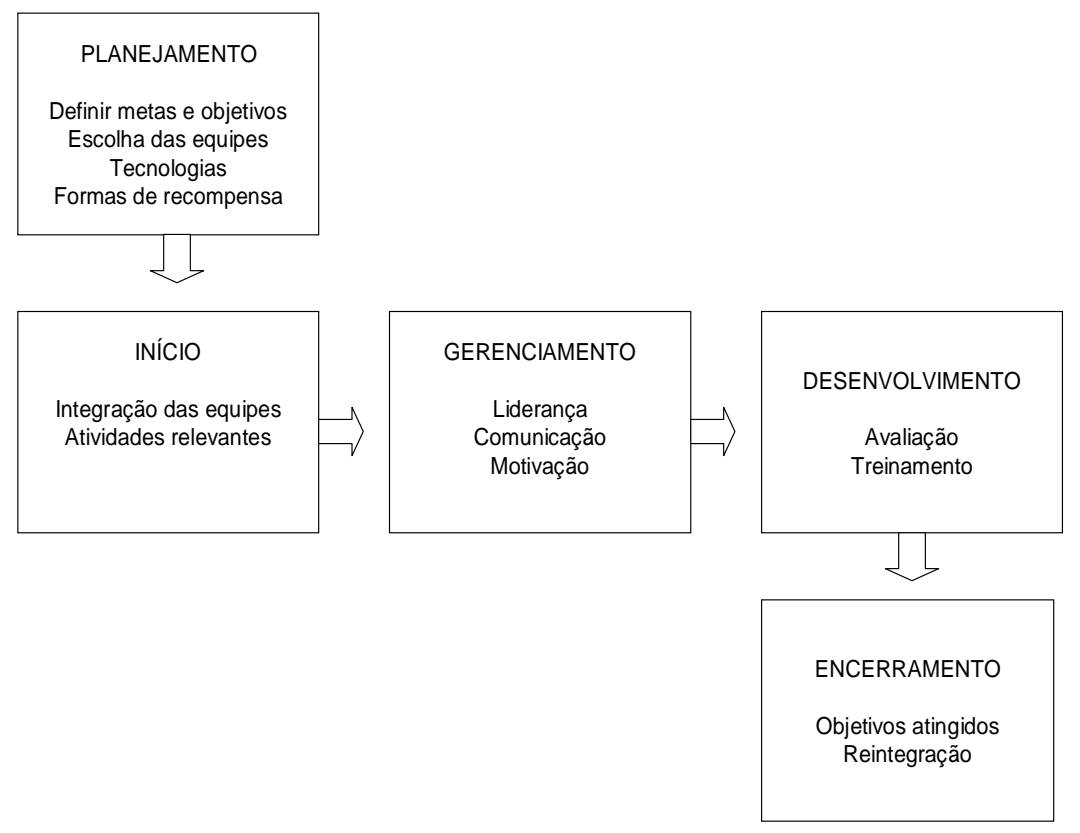

Figura 5. Modelo do ciclo de vida para o gerenciamento das equipes virtuais Fonte: Hertel et al (2005)

Portanto, pode-se conceber que um projeto colaborativo é um projeto distribuído, isto é, nele a equipe de projeto é formada por membros de organizações distintas e existe um esforço conjunto por parte das diferentes organizações na geração do resultado final. Por conjunto, entende-se que ambas as empresas discutem e cooperam para a geração das soluções de projeto. Considera-se neste trabalho que a equipe pode ser virtual (no sentido de 
que o mesmo é medido por tecnologia de informação) ou não. Esse não seria um aspecto central para esta pesquisa.

Considerando essas características, adota-se a definição sintetizada por Araújo (2008, p. 21): “os projetos colaborativos são aqueles onde há um esforço compartilhado no conteúdo e, portanto, prazos, metas e o controle gerencial negociados; independentemente se as equipes de cada organização estão em um mesmo local (colaborativo e co-localizado) ou as equipes trabalham distribuídas (colaborativo e distribuído)".

\subsection{Projetos colaborativos: vantagens e dificuldades}

Os projetos colaborativos de desenvolvimento de produtos podem oferecer um conjunto de vantagens aos participantes. Na opinião de Sivadas e Dwyer (2000) e Chesbrough (2003), essas vantagens começam a partir do momento em que os projetos tenham um contínuo fluxo de informações entre os parceiros para garantir uma integração e flexibilidades melhores.

Esta linha de pensamento também é confirmada por Kleinsmann e Valkenburg (2005) que afirmam que uma colaboração é solidificada por uma comunicação efetiva em todas as fases que envolvem o projeto.

Na visão de Hagedoorn (1993), Griffin (1997), Barnes; Pashby e Gibbons (2002), Lam e Chin (2004) e Knudsen (2007) esses projetos podem apresentar as seguintes vantagens:

- redução de custos, de riscos e falhas;

- acesso a novos conhecimentos e competências;

- novos recursos para novas tecnologias;

- compartilhamento de informações desde que todo o processo seja estruturado com o auxilio de técnicas e ferramentas de gerenciamento de projetos; 
- atender mais rapidamente as demandas de mercado.

Conforme Von Stamm (2004), a colaboração entre agentes para desenvolver novos produtos pode proporcionar às empresas melhorias em seus processos internos e também um novo corpo de conhecimento.

Porém Hamel, Doz e Prahalad (1989), Dodgson (1992), Grudin (1994) Domazet et al (2000), Barnes, Pashby e Gibbons (2002) e Lam, Chin e Pun (2007) descrevem alguns fatores que podem dificultar a consecução desses projetos:

- a quebra de sigilo em informações, experiências ou conhecimentos que não estejam no âmbito da colaboração é um risco, pois possibilita um dos agentes não somente adquirir as competências ao desenvolvimento de produtos, mas ter acesso aos demais negócios da empresa parceira;

- gerenciamento insipiente ou falta de liderança que podem facilitar a perda de controle sobre todo o processo, a desmotivação e o desentendimento entre as equipes;

- dispersão geográfica e também a utilização de diferentes recursos computacionais comprometem o processo;

- existência de agendas ocultas ${ }^{17}$;

- níveis diferenciados de conhecimentos em relação aos assuntos técnicos e das especificações do produto;

- desacordos e conflitos que poderão surgir entre as partes em virtude das diferentes práticas utilizadas nos procedimentos que envolvam o desenvolvimento do produto;

- diferenças culturais entre as partes principalmente relacionadas ao idioma.

\footnotetext{
${ }^{17}$ Interesses alheios aos propósitos e objetivos dos projetos colaborativos.
} 
Além de problemas relacionados ao idioma, Schneider (1995) apresenta outras diferenças culturais que podem pôr em risco todo o projeto. São elas:

- estilos de atuação: cada cultura tem seu próprio estilo (paciência, flexibilidade, ponderação) e que pode variar muito. Se esses estilos não forem sincronizados, certamente o sucesso do projeto será prejudicado;

- experiência profissional: em algumas culturas, as pessoas com mais idade e experiência profissional são consideradas mais influentes e com o perfil indicado para assumir maiores responsabilidades ou a gerência dos projetos; Para outras culturas, os níveis de maior responsabilidades de um projeto são delegados às pessoas em idade não tão avançada, por considerar que possuem mais disposição, dinamismo e pro atividades;

- aproveitamento do tempo: algumas culturas fazem um melhor uso do tempo, dividindo as tarefas e atividades, outras culturas "pulverizam" o tempo, ou seja, procuram realizar várias tarefas e atividades conjuntamente, não estabelecendo prioridades, prejudicando assim os resultados globais de um projeto;

A figura 6 mostra as vantagens e as dificuldades encontradas no gerenciamento dos projetos colaborativos de desenvolvimento de produtos na visão do grupo dos pesquisadores citados nesta seção. 


\section{Projetos colaborativos: vantagens e dificuldades}

\begin{tabular}{|c|c|c|}
\hline $\begin{array}{l}\text { Barnes } \\
\text { Chin } \\
\text { Gibbons } \\
\text { Griffin } \\
\text { Hagedoorn } \\
\text { Knudsen } \\
\text { Lam } \\
\text { Pashby } \\
\text { Van Stamm }\end{array}$ & VANTAGEN & $\begin{array}{l}\text {-Redução de custos, riscos e falhas } \\
\text {-Acesso a novos conhecimentos e competências } \\
\text {-Novos recursos e tecnologias } \\
\text {-Atender mais rapidamente às demandas de mercado } \\
\text {-Melhoria dos processos internos } \\
\text {-Compartilhamento de informações com o auxílio das } \\
\text { técnicas e ferramentas de gerenciamento de projetos }\end{array}$ \\
\hline $\begin{array}{l}\text { Barnes } \\
\text { Chin } \\
\text { Dodgson } \\
\text { Domazet } \\
\text { Grudin } \\
\text { Hamel } \\
\text { Lam } \\
\text { Pun }\end{array}$ & DIFICULDAD & $\begin{array}{l}\text {-Quebra de sigilo em informações alheias à } \\
\text { colaboração } \\
\text {-Falta de liderança / Gerenciamento insipiente } \\
\text {-Dispersão geográfica } \\
\text {-Utilização de diferentes recursos computacionais } \\
\text {-Níveis diferenciados de conhecimentos } \\
\text {-Falhas de comunicação } \\
\text {-Diferenças culturais }\end{array}$ \\
\hline
\end{tabular}

Figura 6. Projetos colaborativos: vantagens e dificuldades (elaborada pelo autor)

Para que os projetos colaborativos possam atingir os objetivos e metas propostas torna-se necessário estabelecer um conjunto de atividades chaves ou fatores críticos de sucesso (FCS) (ROMANO, 2003). Esse conjunto de atividades ou FCS serão explicados no capítulo seguinte, que descreverá também os trabalhos científicos que foram pesquisados na revisão bibliográfica e que citam vários fatores críticos de sucesso genéricos. 


\section{MODELOS DE FATORES CRÍTICOS DE SUCESSO NO GERENCIAMENTO DE PROJETOS COLABORATIVOS}

Este capítulo descreve os fatores críticos de sucesso (FCS) em projetos colaborativos de desenvolvimento de produtos. A seção 4.1 apresenta a definição e um conjunto de fatores críticos de sucessos identificados na revisão bibliográfica; a seção 4.2 traz o modelo teórico de Barnes, Parshby e Gibbons; a seção 4.3. mostra o gerenciamento de riscos em projetos; a seção 4.4 traz uma síntese dos FCS do modelo de Barnes, Parshby e Gibbons; e a seção 4.5 analisa o modelo teórico para a pesquisa de campo.

\subsection{Definição e revisão dos fatores críticos de sucesso em projetos colaborativos}

Para Rockart (1979), os FCS formam um conjunto de variáveis ou de atividades chaves em que os resultados favoráveis são absolutamente necessários para os gerentes atingirem em seus objetivos. Orientando-se pelas considerações feitas pelo referido autor, foram selecionados durante a revisão bibliográfica quatro trabalhos que identificavam FCS em projetos colaborativos de desenvolvimento de produto. Esses trabalhos são descritos na seqüência.

O primeiro trabalho é o dos pesquisadores Barczak e Wilemon (2001). Esses pesquisadores enviaram por intermédio do correio eletrônico um questionário estruturado para um conjunto de empresas que realizaram projetos colaborativos em DP com outras organizações. Os pesquisadores não citaram no trabalho quais eram essas organizações. O objetivo do questionário era identificar os FCS sobre o gerenciamento dos projetos colaborativos de desenvolvimento de produtos. Foram incluídas empresas de diversos segmentos entre eles: tecnologia médica, software, telecomunicações, biotecnologia e automação industrial, localizadas em várias regiões dos Estados Unidos. Após o retorno dos 
questionários respondidos, os pesquisadores entrevistaram por telefone os gerentes de projetos. Esses gerentes tinham a formação em engenharia e outras graduações, sendo que alguns tinham curso de mestrado. A experiência profissional média em gerência de projetos de cada um era em torno de 10 anos. As entrevistas tiveram em média 90 minutos e foram gravadas. Os projetos tinham a duração média de 20 meses. Após a realização dos trabalhos, esses pesquisadores identificaram 6 atividades-chave ou fatores críticos de sucesso em comum entre as empresas que fizeram a colaboração:

- comprometimento e comunicação entre as equipes;

- objetivos dos projetos bem definidos;

- $\quad$ sistema de premiação das equipes definido;

- liderança efetiva;

- suporte da alta administração;

- gerenciamento dos níveis de conflito e estresse.

O segundo trabalho foi o de Hyväri (2006). Este pesquisador realizou um survey com 78 empresas finlandesas de vários setores de atividade. Os mais representativos eram telecomunicações e softwares com 25 empresas; o setor de manufatura, com 15 empresas e setor de engenharia e construção civil com 15 empresas. O objetivo foi identificar os principais FCS em projetos colaborativos. Um questionário foi enviado via correio eletrônico aos respondentes (gerentes de projetos com 12 anos de experiência em média) entre dezembro de 2002 até fevereiro de 2003. Os FCS mais freqüentemente mencionados pelos respondentes foram:

- definição das metas e objetivos;

- $\quad$ apoio da alta administração;

- disponibilidade de recursos materiais e financeiros; 
- liderança.

O terceiro trabalho pesquisado foi o dos pesquisadores Heinz et al (2006). Esses pesquisadores analisaram 56 projetos entre empresas de vários segmentos industriais da Alemanha. Os segmentos eram: eletrônico/tecnologia de semicondutores, 44\%; biotecnologia/farmacêutico/químico, 25\%; tecnologia de larga escala (espacial, aviões e militar, 18\%); tecnologia automobilística, 13\%. O objetivo era identificar os FCS. Os pesquisadores enviaram o questionário por correio eletrônico. No total, 450 empresas foram selecionadas. Após o recebimento, compilação e análises dos questionários respondidos, os seguintes FCS foram identificados:

- objetivos mútuos e bem definidos;

- autonomia nas decisões;

- confiança e espírito de equipe;

- qualidade no fluxo das informações e comunicação freqüente entre as equipes;

- apoio da alta administração.

Por fim, pesquisou-se o trabalho de Barnes, Pashby e Gibbons (2006). Esses pesquisadores identificaram por intermédio de revisões bibliográficas e em estudos de casos, os seguintes FCS em projetos colaborativos entre indústria-indústria:

- definições de objetivos e responsabilidades;

- conhecimentos especializados e habilidades complementares;

- $\quad$ transparência e clareza;

- etapas parciais ou marcos do projeto definidos;

- recursos adequados;

- $\quad$ experiências anteriores em colaboração; 
- monitoramento constante e comunicação eficiente;

- gerente de projeto capacitado e com experiência;

- $\quad$ benefícios mútuos e igualdade de poder e contribuição;

- Influências do ambiente;

- confiança, comprometimento, liderança, aprendizado, continuidade, bom relacionamento entre as equipes e um champion em colaboração ${ }^{18}$.

Os estudos de casos desses pesquisadores foram realizados com seis empresas que participam de um programa de colaboração entre universidade e empresa da Warwick University do Reino Unido e foram projetados para testar a influência que os FCS identificados na literatura tiveram no resultado de cada empresa. Os métodos de coletas de dados foram três: entrevistas - questionário com perguntas estruturadas; dados internos das empresas; e observação direta em reuniões sobre o andamento dos projetos. Um dos diferenciais do estudo conduzido por esses autores é o fato de ter sido acompanhado por uma extensa revisão bibliográfica, considerando vários trabalhos sobre colaboração em desenvolvimento de produto. O Quadro 5 apresenta todos os FCS que foram identificados nas pesquisas e descritos em cada um dos quatro trabalhos citados. É interessante observar que alguns desses fatores estão presentes na maioria dos trabalhos relacionados e são identificados com os campos preenchidos na cor cinza. O FCS "estabelecimento dos objetivos e das responsabilidades" é citado nos quatro trabalhos que foram selecionados. Na seqüência, aparecem o "suporte da alta administração", os "recursos adequados", a "liderança", a "confiança e comprometimento" e a "comunicação eficiente", como os mais referenciados. Outro aspecto a ser observado é que, apesar da aparente e grande quantidade de fatores, todos os autores afirmam também que há necessidade de novas verificações e que é possível a existência de outros ainda não identificados.

\footnotetext{
${ }^{18}$ Para os pesquisadores, trata-se de uma pessoa que motive o grupo envolvido nos projetos.
} 


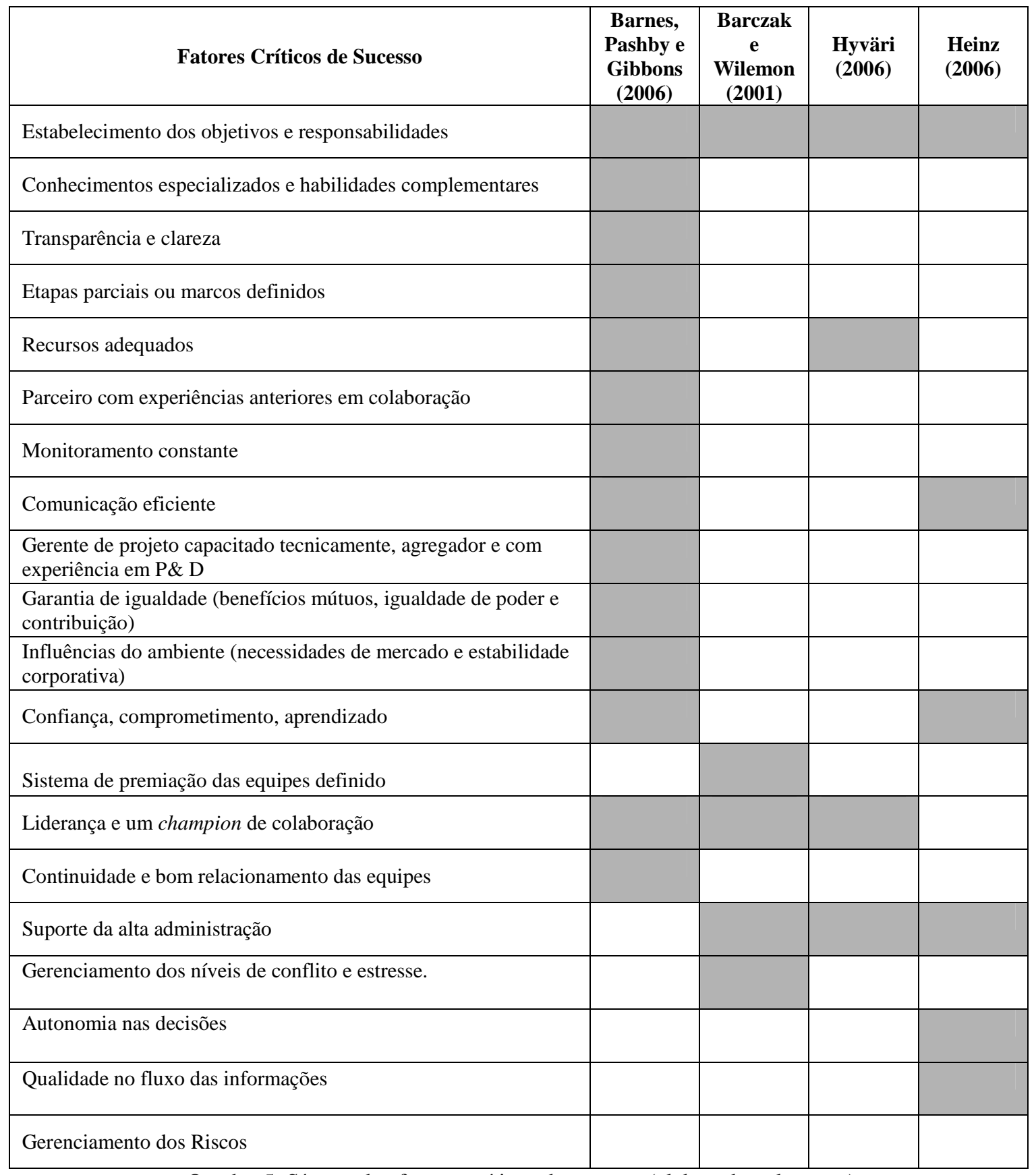

Quadro 5. Síntese dos fatores críticos de sucesso (elaborado pelo autor)

O FCS “gerenciamento de riscos”, uma das áreas de conhecimento do gerenciamento de projetos, não foi descrito em nenhum dos trabalhos relatados nesta seção. É um FCS importante para o gerenciamento de projetos colaborativos. A seção 4.3 descreve o gerenciamento de riscos em projetos. Esta importância para o gerenciamento de riscos pode ser constatada em um estudo de caso realizado pelos pesquisadores Van Wyk, Bowen e 
Akintoye (2008) em uma empresa de grande porte localizada na África do Sul em que é apresentada a relevância deste FCS no gerenciamento de projetos. Segundo os autores, a direção da empresa considera o gerenciamento de riscos em projetos um assunto que compõe o planejamento estratégico da empresa. Todas as unidades de negócios e subsidiárias da empresa situadas nos país possuem um comitê composto por executivos que têm por objetivos desenvolver estratégias para gerenciar todo e qualquer tipo de risco em projetos. $\mathrm{O}$ gerenciamento de risco em projetos desperta a atenção de pesquisadores para o desenvolvimento de ferramentas de apoio. Neste cenário, Kayis et al (2007) desenvolveram um software ${ }^{19}$ para realizar com eficácia todo o gerenciamento de riscos, integrando de forma sistemática o desenvolvimento de produtos e processos.

\subsection{O modelo teórico de Barnes, Pashby e Gibbons}

Os pesquisadores ingleses, Tina Barnes, Anne Gibbons e Ian Pashby realizaram um trabalho com o objetivo de identificar os FCS na colaboração em DP entre universidade e a indústria. Eles dividiram o trabalho em duas etapas:

- a revisão bibliográfica;

- estudos de casos em empresas.

Após a realização das etapas, observaram que FCS encontrados na literatura também foram detectados durante a realização dos estudos de caso entre a universidade e indústrias. A partir destas similaridades, Barnes, Pashby e Gibbons (2006) desenvolveram um modelo teórico que intitularam de "modelo de boas práticas" e que em seu teor foram incorporados os FCS na gestão de projetos colaborativos em DP. Estes pesquisadores argumentam que, apesar do modelo estar direcionado para a colaboração universidade-empresa, ele pode ser utilizado

\footnotetext{
${ }^{19} \mathrm{O}$ software chama-se IRMAS - Intelligent Risk Mapping and Assessment System
} 
para a colaboração entre indústria-índústria. Esse modelo teórico foi considerado o mais apropriado e por isso é utilizado como fonte principal nesta dissertação para a descrição de cada FCS. O modelo foi estruturado em cinco áreas contendo vários FCS e é apresentado na figura 7. A figura indica a relação entre as áreas principais ou categorias de FCS. As áreas são:

- diferencas culturais: dizem respeito ao alinhamento de prioridades entre a universidade e a empresa;

- parceiro: os fatores críticos de sucesso são aqueles que estão relacionados à escolha dos parceiros e as competências do gerente de projeto. São mais aplicáveis no início do projeto porque influenciam a formação do time da colaboração;

- projeto: indicam características que devem estar presentes durante o estágio do planejamento, execução e controle do projeto;

- resultados: esta área é uma classificação, pois compõe, contém ou agrupa FCS. A idéia é que uma colaboração eficaz precisa gerar resultados e que a existência deles é fundamental para a continuidade. Exemplos de resultados são: inovação tecnológica, a publicação de artigos e o registro de patentes para novos produtos;

- fatores universais de sucesso: formada por aspectos gerais que devem estar presentes em qualquer tipo de relacionamento de colaboração, por exemplo: a confiança, a liderança, um champion de colaboração, o comprometimento, o aprendizado, a continuidade e o bom relacionamento das equipes; 


\section{MODELO TEÓRICO DE BARNES, PARSHBY E GIBBONS}

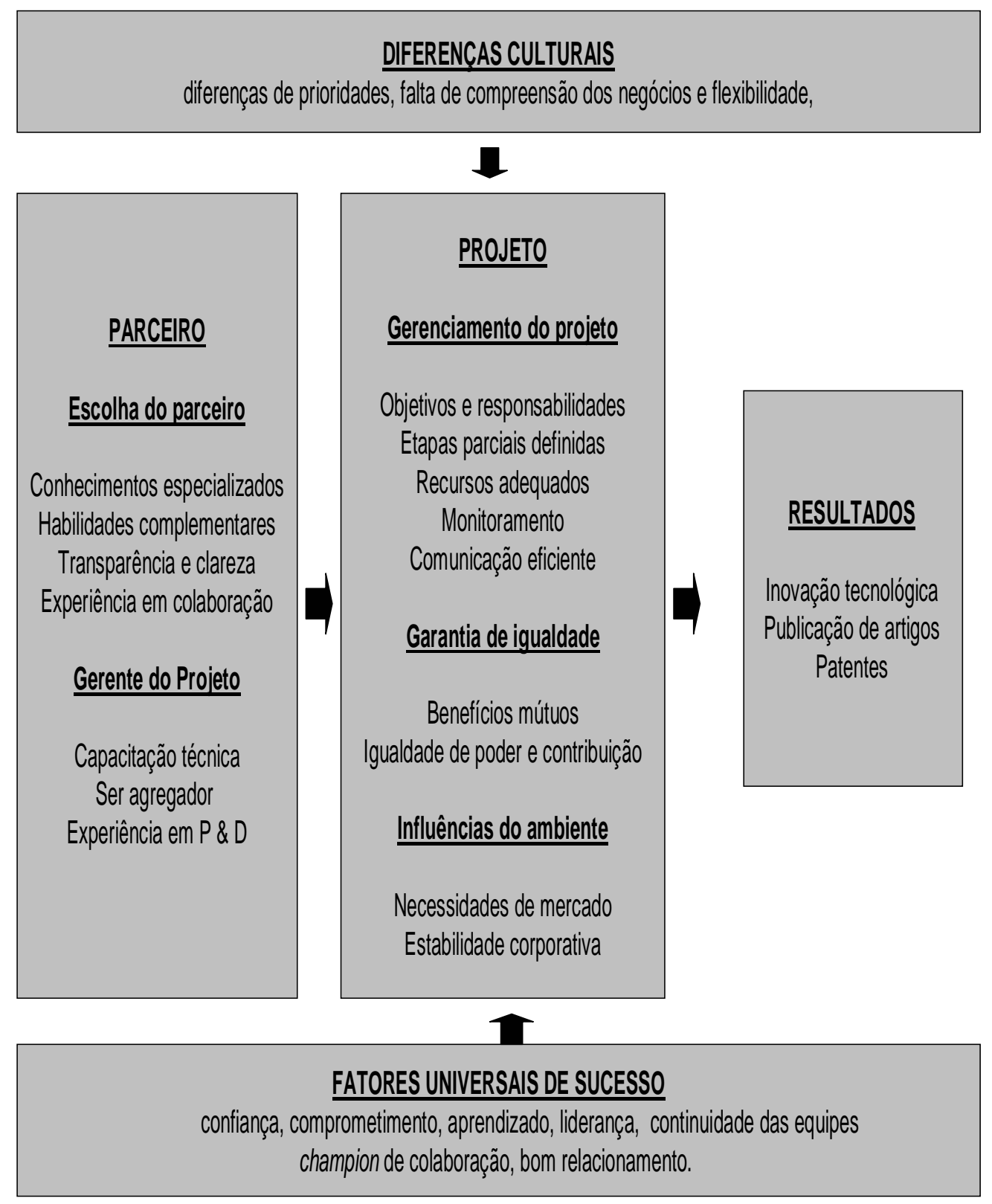

Figura 7. Modelo Teórico de Barnes, Pashby e Gibbons (adaptado pelo autor) Fonte: International Journal of Project Management 24 -2006 - pg.398 


\subsection{O gerenciamento de riscos em projetos}

O gerenciamento de riscos em projetos é uma das áreas do conhecimento da gestão de projetos. Durante todas as etapas de um processo de planejamento para se atingir as metas e os objetivos de um projeto é necessário identificar, desenvolver ações e controlar os riscos de falhas que podem comprometer todo um trabalho.

De acordo com Heldman (2003), em um ambiente de projeto, os riscos podem ser tanto internos como externos, alguns são conhecidos antecipadamente, porém, outros podem acontecer de forma inesperada durante o ciclo de vida do projeto. Para os riscos que podem ser identificados há ferramentas e técnicas que podem ser utilizadas e para aqueles que não podem ser identificados, a única resposta possível é a alocação de uma contingência geral para o caso de sua ocorrência (HELDMAN, 2003; ALBENY, 2007).

O PMBoK (2004) relaciona as seguintes ferramentas e técnicas que poderão ser utilizadas para a identificação dos riscos:

- revisões de documentação;

- técnicas de coletas de informações: brainstorming, Técnica Delphi, entrevistas, identificação da causa-raiz, análise dos pontos fortes e fracos, das ameaças e das oportunidades;

- análise da lista de verificação;

- análise das premissas;

- técnicas de diagramas: diagramas de causa e efeito, diagramas do sistema ou fluxogramas, diagramas de influência.

Para Van Wyk, Bowen e Akintoye (2008), o gerenciamento de riscos é um aspecto dentro da disciplina de gerenciamento de projeto que tem por objetivo desenvolver um conjunto de ações que visam reduzir as incertezas que poderão surgir durante o ciclo de vida 
de um projeto. De acordo com Verzuh (2000), o gerenciamento de riscos é uma forma disciplinada pela qual a incerteza é gerenciada para aumentar a probabilidade de cumprir os objetivos de um projeto.

O PMBoK (2004) define o termo "risco" em projetos como um evento ou condição incerta que, se ocorrer, terá um efeito positivo ou negativo sobre pelo menos um objetivo do projeto, como tempo, custo, escopo ou qualidade.

Os objetivos do gerenciamento de riscos do projeto são aumentar a probabilidade e o impacto dos eventos positivos e diminuir a probabilidade e o impacto dos eventos adversos ao projeto (PMBoK, 2004).

Heldman (2003) descreve que os riscos podem ou não afetar o projeto negativamente e propõe onde é possível encontrá-los: orçamentos, cronogramas, mudança no escopo ou nos requisitos, problemas técnicos, com pessoal, hardware, contratos, assuntos políticos, risco de negócio, risco legal, risco ambiental.

Para Hullet $(2002)^{20}$, citado por Rovai (2005), os riscos deverão ser listados por categorias e identificadas suas possíveis causas e gatilhos (os elementos que eclodem o risco) para eventuais ações sobre esses elementos, visando reduzir os agentes causais do risco e as prováveis conseqüências dos riscos sobre o projeto.

Essas categorias são classificadas de acordo com o PMBoK (2004) em:

- riscos técnicos: utilização de tecnologias inadequadas, mudanças na tecnologia usada ou nas normas industriais durante o projeto, exigência de atingir metas de desempenho não-realistas;

\footnotetext{
${ }^{20}$ Hulett, D. T. Key characteristics of a mature risk management process. New York: International Institute for Learning, 2002
} 
- riscos organizacionais: objetivos de custo, prazo e escopo que são internamente incoerentes, faltas de priorização dos projetos, conflitos sobre recursos com demais projetos da empresa;

- riscos externos: alterações em leis e regulamentos, mudanças em tendências de mercado, questões trabalhistas, modificações de prioridades de patrocinadores e proprietários, alterações meteorológicas;

- riscos de gestão de projetos: a alocação inadequada de tempos e recursos, qualidade inadequada do plano do projeto, uso inadequado de disciplinas da gestão de projetos, estimativas irrealistas ou incompletas, problemas com fornecedores ou subcontratantes, técnicas deficientes de comunicação e inabilidade ao tomar decisões do projeto.

O gerenciamento de riscos forma um conjunto de processos. O PMBoK (2004) descreve seis processos, a saber:

- planejamento do gerenciamento de riscos: decide como abordar e executar as atividades de gerenciamento de riscos de um projeto. É importante para garantir que o nível, tipo e visibilidade do gerenciamento de riscos estejam de acordo com a importância do projeto em relação à organização, para fornecer tempo e recursos suficientes para as atividades de gerenciamento de riscos e para estabelecer uma base acordada de avaliação de riscos. Descreve as funções e responsabilidades das pessoas participantes, o orçamento e a freqüência dos processos de gerenciamento de riscos, o monitoramento e atualização das informações. Neste processo, são realizadas reuniões entre os participantes responsáveis pelo gerenciamento dos riscos; 
- identificacão de riscos: determinação dos riscos que podem afetar o projeto e documentação de suas características.

- análise qualitativa de riscos: avalia a prioridade dos riscos identificados usando a probabilidade deles ocorrerem, além de outros fatores, como o prazo e tolerância a risco das restrições de custo, cronograma, escopo e qualidade do projeto. Heldman (2003) afirma que esta análise deve ser efetuada em todo ciclo do projeto. De acordo com Rovai (2005), a análise qualitativa sempre fornecerá um universo maior e mais consistente de informações, mas esbarra em muitos casos na falta de recursos de pessoas qualificadas e técnicas adequadas.

- análise quantitativa de riscos: é realizada nos riscos que foram priorizados pelo processo anterior (análise qualitativa de riscos), por afetarem potencial e significativamente as demandas conflitantes do projeto. Este processo analisa o efeito desses eventos de risco e atribui uma classificação numérica a esses riscos e também apresenta uma abordagem quantitativa para a tomada de decisões na presença da incerteza. Existem ferramentas e técnicas para este processo tais como: entrevistas, distribuições de probabilidades, análise de sensibilidade, análise da árvore de decisões e simulações.

- planejamento de respostas a riscos: especifica as etapas a serem tomadas para reduzir as ameaças e tirar proveito das oportunidades durante os processos de análise de riscos. Também engloba atribuir aos departamentos ou a integrantes da equipe a responsabilidade de executar planos de respostas aos riscos que serão previstos nesse processo. Nesse processo são usadas várias estratégias para reduzir ou controlar o risco: 
a. estratégias para riscos negativos ou ameaças: prevenção, a transferência e a mitigação;

b. estratégias para riscos positivos: exploração, compartilhamento e melhoria;

c. estratégias para ameaças e oportunidades: aceitação.

- monitoramento e controle de riscos: acompanhamento dos riscos identificados, identificação dos novos riscos, execução de planos de respostas a riscos e avaliação da sua eficácia durante todo o ciclo de vida do projeto. Neste processo, também são utilizadas algumas ferramentas e técnicas tais como: a reavaliação de riscos, auditoria de riscos, análise das tendências e variação, medição do desempenho técnico, análise das reservas.

Os processos que compõem o gerenciamento de riscos interagem entre si (figura 8) e também com processos de outras áreas de conhecimento.

Cada processo pode envolver o esforço de uma ou mais pessoas ou grupos de pessoas, com base nas necessidades do projeto, podendo ocorrer pelo menos uma vez em todos os projetos e também em uma ou mais fases do projeto, se ele estiver dividido em fases. 
GERENCIAMENTO DE RISCOS DO PROJETO

\subsection{Planejamento} do gerenciamento de riscos

\section{.1. Entradas}

.1 Fatores ambientais da empresa

2 Ativos de processos

organizacionais

3 Declaração do escopo do projeto

.4 Plano de gerenciamento do projeto

.2 Ferramentas e técnicas

.1 Análise e reuniōes de

planejamento

3 Saídas

.1 Plano de gerenciamento de riscos

\subsection{Análise quantitativa} de riscos

\section{Entradas}

.1 Ativos de processos

organizacionais

2 Declaração do escopo do projeto

.3 Plano de gerenciamento de ríscos

4 Registro de riscos

.5 Plano de gerenciamento do

projeto

- Plano de gerenciamento do

cronograma do projeto

- Plano de gerenciamento de custos do projeto

.2 Ferramentas e técnicas

1 Técnicas de representação

e coleta de dados

.2 Análise quantitativa de riscos e técnicas de modelagem

.3 Saídas

.1 Registro de riscos (atualizaçōes)

\subsection{Identificação de riscos}

1 Entradas

.1 Fatores ambientais da empresa

2 Ativos de processos

organizacionais

.3 Declaração do escopo do projeto

.4 Plano de gerenciamento de riscos

5 Plano de gerenciamento do projeto

2 Ferramentas e técnicas

.1 Revisōes da documentação

.2 Técnicas de coleta de informações

3 Análise da lista de verificação

4 Análise das premissas

5 Técnicas com diagramas

3 Saídas

.1 Registro de riscos

\subsection{Planejamento de} respostas a riscos

\section{Entradas}

.1 Plano de gerenciamento de riscos

2 Registro de riscos

2 Ferramentas e técnicas

1 Estratégias para riscos negativos ou ameaças

2 Estratégias para riscos positivos ou oportunidades

3 Estratégia para ameaças e oportunidades

4 Estratégia para respostas

contingenciadas

\section{.3 Saídas}

.1 Registro de riscos (atualizações)

2 Plano de gerenciamento do projeto (atualizaçōes)

3 Acordos contratuais relacionados a riscos
11.3 Análise qualitativa de riscos

\section{.1 Entradas}

1 Ativos de processos

organizacionais

2 Declaração do escopo do projeto

3 Plano de gerenciamento de riscos

.4 Registro de riscos

.2 Ferramentas e técnicas

1 Avaliação de probabilidade e

impacto de riscos

.2 Matriz de probabilidade e impacto

.3 Avaliação da qualidade dos dados

sobre riscos

.4 Categorização de riscos

5 Avaliaçăo da urgência do risco

3 Saídas

.1 Registro de riscos (atualizaçòes)

\subsection{Monitoramento} e controle de riscos

1 Entradas

.1 Plano de gerenciamento de riscos

.2 Registro de riscos

.3 Solicitaçōes de mudança aprovadas

4 Informaçōes sobre o desempenho do trabalho

.5 Relatórios de desempenho

2 Ferramentas e técnicas

1 Reavaliação de riscos

.2 Auditorias de riscos

.3 Análise das tendências e da variação

4 Medição do desempenho tếcnico

.5 Análise das reservas

.6 Reuniōes de andamento

.3 Saídas

1 Registro de riscos (atualizações)

2 Mudanças solicitadas

3 Açōes corretivas recomendadas

.4 Açōes preventivas recomendadas

.5 Ativos de processos

organizacionais (atualizações)

.6 Plano de gerenciamento do

projeto (atualizaçōes)

Figura 8. Visão geral do gerenciamento de riscos de um projeto

Fonte: PMBOK (2004, p. 239) 


\subsection{Síntese dos FCS do modelo de Barnes, Parshby e Gibbons}

Esses pesquisadores definiram quase todos os FCS de seu modelo teórico. Dois não foram definidos, apenas citados.

$\mathrm{Na}$ área "Diferenças Culturais", os FCS "diferenças de prioridades" e "falta de compreensão dos negócios", na visão dos autores acima citados refletem os problemas existentes entre a universidade e o parceiro industrial da colaboração. Tais problemas podem ser evidenciados pela falta de sensibilidade dos pesquisadores acadêmicos em relação às prioridades do parceiro industrial. Os autores descrevem o que significa para a universidade "prioridade":

- atingir os objetivos em suas atividades de pesquisas em um período mais longo de tempo;

- a publicação dos resultados de trabalhos em jornais acadêmicos;

- o aprendizado nos cursos.

Para o parceiro industrial, um período mais longo de tempo gera conflitos com a universidade apresentando como resultado a perda do parceiro patrocinador, porém completam que os problemas associados a ela (prioridade) podem ser atenuados por intermédio de um bom diálogo e gerenciamento da colaboração.

Já em relação ao FCS “transparência e clareza”, os autores afirmam que quanto mais os atores envolvidos na colaboração agirem de forma nítida e objetiva, sem ocultar nenhum tipo de informação que se faça necessária para o bom andamento dos trabalhos, o nível de confiabilidade será reforçado e o empreendimento terá possibilidades de atingir os objetivos propostos dentro dos prazos estabelecidos, além de garantir colaborações futuras.

Em relação ao FCS "experiência anterior em colaboração", os autores argumentam que pode ser prestativa em relação ao fortalecimento da confiança entre os parceiros e ganhos 
de tempo e mais aportes tecnológicos. Ainda na categoria "Parceiro", mais especificamente aos FCS relacionados ao "gerente de projeto" (capacitação técnica, ser agregador e com experiência em P \& D), os autores argumentam que é necessário ter um processo de seleção adequado na escolha deste profissional. Esta escolha vai refletir a importância colocada na qualidade e competência do gerente de projeto. Além disso, afirmam que os projetos colaborativos necessitam de um gerente de projeto que harmonize os diferentes objetivos, perspectivas e modos de operação dos parceiros e mesmo não tendo autoridade direta necessária, precisa ter diplomacia para assegurar que as entregas dos parceiros sejam realizadas com o intuito de atingir os objetivos desejados.

Para os autores, é valioso o gerente de projeto ter um grau de conhecimento técnico e alguma experiência em ambientes de pesquisa e desenvolvimento, pois isso permite entrosamento e credibilidades melhores com a equipe, além de criar um estilo apropriado ao gerenciamento.

Para a área "Projeto", os autores consideram importante a clara definição dos objetivos e das responsabilidades, a definição das metas ou etapas parciais para se chegar aos objetivos principais, bem como a utilização adequada dos recursos e do tempo disponível. E para que os objetivos sejam cumpridos, é necessária a criação de um plano de trabalho que conste as atividades e compromissos dos parceiros. Destacaram também que em alguns dos casos estudados por eles, os planos de trabalhos não foram seguidos ou faltavam detalhes suficientes, nesses casos em particular, os parceiros industriais perderam a confiança no projeto.

O modelo destaca uma estratégia efetiva de comunicação, combinando mecanismos formais para as reuniões estratégicas e para o gerenciamento diário uma comunicação informal com o objetivo de fortalecer o espírito e a confiança das equipes. Foi verificado 
pelos autores que algumas empresas participantes do estudo de caso, criaram "fóruns de grupos dirigidos", compostos por pessoas "chaves" que participam dos projetos e que regularmente se encontram para discutir o andamento dos trabalhos. Este grupo tem por objetivo supervisionar o trabalho da colaboração e age como um elo entre o projeto e os participantes individualmente, permitindo a essas empresas receber informações atualizadas.

Em relação ao FCS "garantia de igualdade", esses autores argumentam que é necessário se atingir benefícios mútuos com o equilíbrio de poder e contribuições, pois, isso fortalece a confiança e também funciona como um elemento facilitador em futuras colaborações.

Para as "influências do ambiente", os autores destacam que a estabilidade corporativa é um fator importante para garantir que os projetos colaborativos tenham um desempenho adequado. Porém ressaltam que possíveis mudanças provenientes de reestruturação da empresa e a troca de gerentes de projetos podem comprometer os projetos que estão em andamento. Outro fator preponderante que pode afetar negativamente o ciclo de vida de um projeto são as dificuldades financeiras que uma empresa possa vir a ter e assim, verbas orçamentárias antes destinadas aos projetos irem para outras finalidades momentâneas. A área "Resultados" reflete o sucesso de um projeto, isto é, o alcance dos objetivos dentro do prazo estabelecido com um custo apropriado ou a frustração do parceiro por não atingir os objetivos estabelecidos. Na área "Fatores universais de sucesso", os autores descrevem que a adição de todos os FCS, principalmente a confiança, faz com que os objetivos estabelecidos na colaboração sejam alcançados com um mínimo de risco possível.

Segundo os autores, a confiança entre os parceiros é um tema fundamental, pois influencia diretamente a eficácia e o sucesso da colaboração e deve estar presente em todo o ciclo de vida do projeto. Para Kadefors (2004), a confiança em uma relação de colaboração 
entre parceiros é um estado de espírito que proporciona o envolvimento de todos para que os resultados do projeto sejam alcançados no tempo certo.

Conforme Bstieler (2006), a confiança entre parceiros de colaboração é um elemento essencial, principalmente no desenvolvimento de novos produtos, pois fortalece a troca de conhecimentos e tecnologias complementares.

Por outro lado, os FCS citados e não definidos pelos autores motivaram uma nova busca em outros trabalhos. Após essa busca, foram identificados dois trabalhos que apresentaram em seu teor uma clara explicação sobre esses FCS não definidos por Barnes et al. Em relação aos FCS "conhecimentos especializados" e "habilidades complementares", Emden, Calantone e Droge (2006), após um estudo feito sobre a colaboração em DP, descreveram que os conhecimentos especializados ou as habilidades complementares incluem uma diversidade de recursos tecnológicos e vasto conhecimento de mercado por parte do parceiro e que pode facilitar a introdução de novos produtos ou a abertura de novos mercados.

Nesta mesma linha de raciocínio, Das e Teng (2000) argumentam que esses dois fatores juntos permitem aos parceiros adquirir uma vantagem competitiva melhor e também um elevado grau de inovação em produto. A figura 9 descreve uma síntese de todos os FCS relacionados no modelo teórico de Barnes, Parshby e Gibbons. Os FCS que foram definidos pelos autores estão destacados por retângulos com preenchimento em cinza e os não definidos aparecem em retângulos brancos. Os FCS aparecem separados em suas respectivas áreas. 


\begin{tabular}{|c|c|c|c|}
\hline Áreas & $\begin{array}{c}\text { Fatores Críticos de Sucesso } \\
\text { do modelo de Barnes, } \\
\text { Pashby e Gibbons }\end{array}$ & Definidos & $\begin{array}{c}\text { Não } \\
\text { Definidos }\end{array}$ \\
\hline \multirow{2}{*}{ Diferenças Culturais } & Diferenças de prioridades & & \\
\hline & $\begin{array}{l}\text { Falta de compreensão dos negócios e } \\
\text { flexibilidade }\end{array}$ & & \\
\hline \multirow{7}{*}{ Parceiro } & Conhecimentos especializados & & \\
\hline & Habilidades complementares & & \\
\hline & Transparência e clareza & & \\
\hline & Experiência anterior em colaboração & & \\
\hline & Capacitação técnica & & \\
\hline & Ser agregador & & \\
\hline & Experiência em P \& D & & \\
\hline \multirow{7}{*}{ Projeto } & Objetivos e responsabilidades, & & \\
\hline & Etapas parciais definidas & & \\
\hline & Recursos adequados & & \\
\hline & Monitoramento & & \\
\hline & Comunicação eficiente & & \\
\hline & Garantia de igualdade & & \\
\hline & Influências do ambiente & & \\
\hline \multirow{3}{*}{ Resultados } & Inovação tecnológica, & & \\
\hline & Publicação de artigos & & \\
\hline & Patentes & & \\
\hline \multirow{7}{*}{$\begin{array}{l}\text { Fatores universais de } \\
\text { sucesso }\end{array}$} & Confiança & & \\
\hline & Comprometimento & & \\
\hline & Aprendizado & & \\
\hline & Liderança & & \\
\hline & Continuidade das equipes & & \\
\hline & Champion da colaboração & & \\
\hline & Bom relacionamento das equipes & & \\
\hline
\end{tabular}

Figura 9. Síntese dos FCS relacionados no modelo de Barnes, Pashby e Gibbons (desenvolvida pelo autor)

\subsection{Modelo teórico para a pesquisa}

Um modelo teórico foi elaborado para estudar a colaboração na IMA e para a sua validação foi aplicado um roteiro de pesquisa para o estudo de caso. Tal modelo foi adaptado 
do de Barnes, Pashby e Gibbons. Esta escolha é justificada, pois, esse modelo é mais abrangente em relação aos demais que foram pesquisados e descritos na seção 4.1.

Barnes, Pashby e Gibbons realizaram uma ampla revisão da literatura sobre o gerenciamento de projetos colaborativos e entrevistaram uma ampla gama de profissionais que atuaram nos projetos, freqüentaram e filmaram reuniões das equipes dos projetos. Porém nem todos os FCS citados em Barnes, Pashby e Gibbons foram utilizados para este modelo adaptado em virtude principalmente do tempo disponível para a execução do roteiro da pesquisa e também da disponibilidade dos respondentes.

Nesta pesquisa, adaptaram-se os construtos de Barnes e demais autores reorganizando-os em quatro áreas, que foram avaliadas no campo. São elas:

- caracterização da empresa;

- colaboração na empresa;

- classificação do projeto;

- avaliação dos fatores críticos de sucesso.

A área "Caracterização da empresa" não apresenta nenhum FCS Ela contém as variáveis que foram utilizadas para descrever a empresa visando à comparação dos resultados com estudos futuros. Procurou-se reunir as dimensões que, conforme os estudos anteriores, poderiam condicionar a colaboração. Incluíram-se dados institucionais, a estrutura organizacional da empresa, a descrição dos produtos e os tipos de projetos de desenvolvimento de produtos (montagem industrial, difusão tecnológica, extensão de linha, novas tecnologias). No que tange aos tipos de projetos de desenvolvimento de produtos, empregou-se as classificações do Manual de Oslo e PINTEC, de forma a permitir no futuro comparações com esses levantamentos de dados. 
Empregou-se apenas uma pequena alteração na dimensão tipos de projeto, denominado de montagem industrial. Este tipo se refere aos produtos nos quais a empresa faz todo o projeto com base em componentes e peças fabricadas sob encomenda, fornecidas por outras empresas. Em seguida, o produtor monta o produto a partir desses componentes. Isto é, a empresa não realiza operações de fabricação. Este tipo foi identificado em estudos de caso e na literatura de bens de capital e, por isso foi adicionado ao estudo. Já para os projetos de difusão tecnológica, o produto é uma adaptação de produtos existentes, licenciados de outras empresas ou de propriedade de empresas do grupo. Os produtos considerados como extensão de linha possuem acréscimos de desempenho, função ou capacidade, ou seja, são produtos já existentes, sem mudança de tecnologia ou funções. Em relação às novas tecnologias, aprofundou-se a classificação indicando duas categorias, novas para a empresa ou para o mercado. Uma nova tecnologia para empresa diz respeito aos produtos com inovações significativas para a empresa, mas não para o mercado na medida que o conhecimento já existe, aplicado em outro produto, mas não pode ser adquirido ou copiado. Há uma nova tecnologia para o mercado quando o produto possui inovações significativas para a empresa e que são uma novidade no mercado.

A área "Colaboração na empresa" contém as variáveis utilizadas para caracterizar o nível com que a empresa faz uso de projetos colaborativos. Verificou-se se a empresa já havia realizado projetos colaborativos com diferentes tipos de envolvidos no projeto (clientes, fornecedores, institutos de pesquisa e etc.). Em seguida, incluiu-se uma variável para medir as motivações gerais para a colaboração. E, por fim, optou-se por investigar os critérios para a escolha do parceiro e qual a importância e objetivo com que foram realizadas as parcerias no passado, com cada um dos diferentes agentes. 
As duas áreas finais envolvem características relacionadas com os projetos em si. Solicitou-se que o respondente escolhesse projetos que haviam sido considerados por eles como de sucesso e que envolveram uma colaboração efetiva. Ambos foram classificados pelo respondente e anotadas as suas argumentações.

O modelo propõe uma análise de cada projeto envolvendo a sua classificação e a identificação dos FCS que estavam presentes. A classificação foi proposta segundo duas dimensões: o tipo de projeto e o objetivo da colaboração. A identificação dos FCS foi realizada por meio de uma lista de 32 fatores críticos de sucesso divididos em 6 áreas, são elas: fatores relacionados ao gerenciamento do projeto; fatores universais de sucesso; gerente do projeto; avaliação do parceiro; garantia de igualdade; e influências do ambiente.

Essa lista foi proveniente das análises apresentadas na seção anterior. Representa uma síntese dos FCS identificados na literatura, ao todo 31, com o acréscimo do fator risco, cuja importância já foi mencionada.

Para melhorar a identificação dos FCS realizaram-se perguntas abertas sobre os benefícios e dificuldades do projeto. Isso permitiu confrontar a coerência entre resposta espontânea e questões fechadas, de forma a se ter um controle mínimo da avaliação do respondente.

A figura 10 ilustra o modelo teórico da pesquisa, o qual foi utilizado para identificar FCS em projetos colaborativos na IMA. 


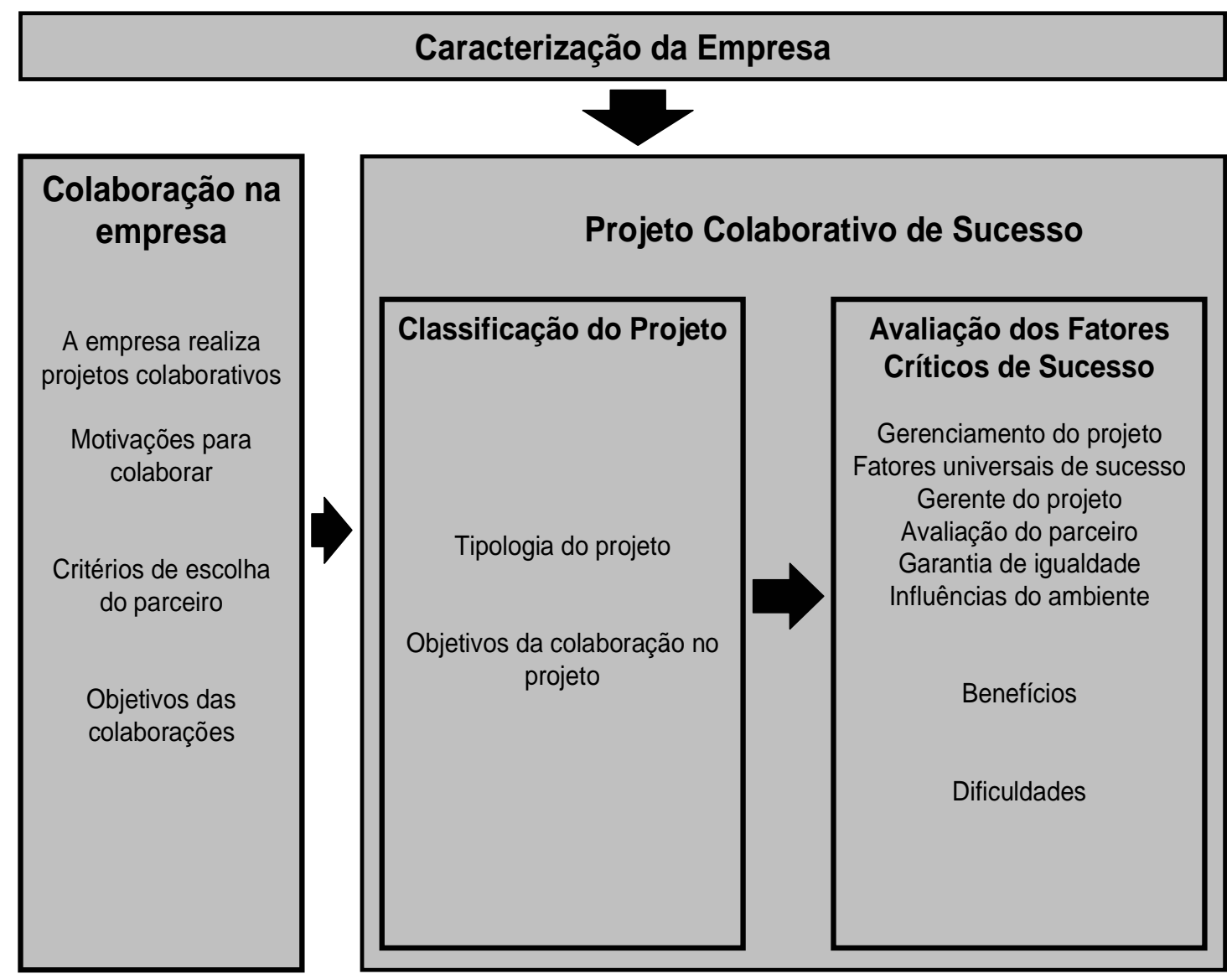

Figura 10. Modelo teórico da pesquisa (elaborado pelo autor)

Este capítulo descreveu um panorama geral sobre os FCS. Apresentou alguns modelos teóricos, bem como descreveu um modelo teórico que foi adaptado para a aplicação nos estudos de campo. O próximo capítulo descreve a metodologia utilizada para a realização desta dissertação. 


\section{MÉTODO}

Este capítulo apresenta o método e os procedimentos utilizados no desenvolvimento do trabalho. A seção 5.1 descreve o método utilizado para a pesquisa, a seção 5.2 a unidade de análise e a seção 5.3 as etapas do trabalho.

\subsection{Método da pesquisa}

As pesquisas são classificadas quanto às abordagens, as suas tipologias e aos métodos empregados para a realização e a obtenção dos resultados pretendidos.

Em relação à abordagem das pesquisas, Rutter (1994) argumenta que as pesquisas são classificadas em quantitativas ou qualitativas. Ainda conforme esse autor as pesquisas quantitativas são utilizadas quando se quer medir a opinião, a reação, hábitos e atitudes de um determinado público-alvo por intermédio de uma amostra estruturada que o represente de forma estatisticamente comprovada. Já as pesquisas qualitativas possuem um perfil não estruturado, ou seja, uma investigação mais aprofundada.

Em relação aos tipos de pesquisas, Churchill e Peter (2000) destacam três principais: exploratórias, descritivas e causais. Segundo esses autores, a pesquisa exploratória procura gerar hipóteses ou explicações prováveis e identificar áreas para um estudo mais aprofundado. A pesquisa descritiva é aquela na qual os problemas a serem investigados estão bem definidos e, em geral, procura-se obter resultados quantitativos sobre aspectos do perfil ou do comportamento humano. A pesquisa causal é a que procura determinar ou testar uma relação de causa e efeito, o seu tipo é o descritivo. A meta é descrever os fatores críticos, tal que possam ser utilizados, em um segundo momento, para levantamentos mais específicos. 
Em relação aos métodos das pesquisas, Oliveira (1999) os define como um conjunto de processos pelos quais se torna possível conhecer uma determinada realidade, produzir determinado objeto ou desenvolver certos procedimentos ou comportamentos.

Para Berto e Nakano (1999), os métodos das pesquisas são as formas que orientam o processo de investigação para uma aproximação e focalização do problema ou fenômeno que se pretende estudar. Esses autores citam que os métodos de pesquisas mais comuns em engenharia de produção são:

- desenvolvimento teórico conceitual: seu escopo principal envolve modelagens conceituais que resultam em novas teorias, não havendo pesquisas de campo;

- levantamento por entrevistas e questionários (survey): colhe informações dos respondentes apropriados sobre um problema a ser estudado e posteriormente, por intermédio de análises quantitativas, apresenta os resultados e as conclusões desses dados;

- estudo de caso: análise aprofundada de um ou mais objetos (casos) e extensas entrevistas não estruturadas com as pessoas envolvidas na situação.

De acordo com Martins (2006), um estudo de caso começa com a carta de intenções delineando-se à medida que se desenvolve com a aplicação de algumas questões orientadoras e colocados pontos críticos que serão explicitados e reformulados com o avanço do mesmo.

Em um estudo de caso, um clima sem perturbações deve ser mantido pelo pesquisador, possibilitando respostas objetivas e solicitação de opiniões sobre fatos; bem como indicações de outros membros da organização que poderão ser entrevistados (Martins 2006, p. 27). 
Na visão de Gil (1995), o estudo de caso não aceita um roteiro rígido para a sua delimitação, mas é possível definir quatro fases que mostram o seu delineamento. Conforme esse autor as quatro fases são:

- delimitacão da unidade-caso: consiste em delimitar a unidade que constitui o caso, o que exige habilidades do pesquisador para perceber quais dados são suficientes para se chegar à compreensão do objeto como um todo;

- coleta de dados: geralmente é feita com procedimentos quantitativos e qualitativos como a observação, análise de documentos, entrevista formal ou informal, história de vida, aplicação de questionário, levantamentos de dados, análise de conteúdo;

- seleção, análise e interpretação dos dados: a seleção dos dados deve considerar os objetivos da investigação, seus limites e um sistema de referências para avaliar quais dados serão úteis ou não. Somente aqueles selecionados deverão ser analisados. $O$ pesquisador deve definir antecipadamente seu plano de análise e considerar as limitações dos dados obtidos, sobretudo no referente à qualidade da amostra, pois se a amostra é boa, há uma base racional para fazer generalizações a partir dos dados. Em caso contrário, deve apresentar os resultados em termos de probabilidade. É importante também utilizar categorias de análise derivadas de teorias que sejam reconhecidas no campo do conhecimento. Isso faz com que a interpretação dos dados não envolva julgamentos implícitos, preconceitos, opiniões de senso comum, etc.;

- elaboracão do relatório: esta fase é representada pela elaboração dos relatórios parciais e finais. Vale lembrar que devem ficar especificados como 
foram coletados os dados; que teoria embasou a categorização dos mesmos e a demonstração da validade e da fidedignidade dos dados obtidos. O relatório deve ser conciso, embora, em algumas situações seja solicitado o registro detalhado.

Yin (2005, p.32) define o estudo de caso como uma investigação empírica de um fenômeno contemporâneo dentro de seus contextos da vida real, especialmente quando os limites entre o fenômeno e o contexto não estão claramente definidos.

Para os estudos de casos, são especialmente importantes cinco componentes de um projeto de pesquisa: as questões de um estudo, as proposições, a (s) unidade (s) de análise (s), a lógica que une os dados às proposições; e os critérios para interpretar as constatações (Yin, 2005, p. 42). Segundo esse autor, as questões mais apropriadas para o estudo de caso são as dos tipos "como" e "por que"; as proposições dizem respeito à essência daquilo que realmente se interessa dentro do escopo do estudo; e a unidade de análise é o que se pretende estudar.

Ainda conforme Yin (2005, p. 47), o quarto e o quinto componente foram os menos desenvolvidos nos estudos de caso. Prenunciam as etapas da análise de dados na pesquisa de estudo de caso, e deve haver um projeto de pesquisa dando base a essa análise. O autor completa dizendo que o estado atual da ciência não fornece uma orientação mais detalhada sobre esses dois componentes.

Para Yin (2005), o método do estudo de caso pode incluir tanto projetos de casos únicos quanto projetos de casos múltiplos.

Pode ser observado pela figura 11 que cada tipo de projeto incluirá o desejo de analisar condições contextuais em relação ao "caso", e as linhas pontilhadas entre os dois indicam que os limites entre o caso e o contexto provavelmente não são bem definidos. Em um segundo momento, a figura mostra que os estudos de caso único e de casos múltiplos 
refletem situações de projetos diferentes e que, dentro desses dois tipos, também pode haver unidades unitárias ou múltiplas de análise.

Os quatro tipos resultantes de projeto para estudos de caso são projetos (holísticos) de caso único (tipo 1), projetos (incorporados) de caso único (tipo 2), projetos (holísticos) de casos múltiplos (tipo 3) e projetos (incorporados) de casos múltiplos (tipo 4).

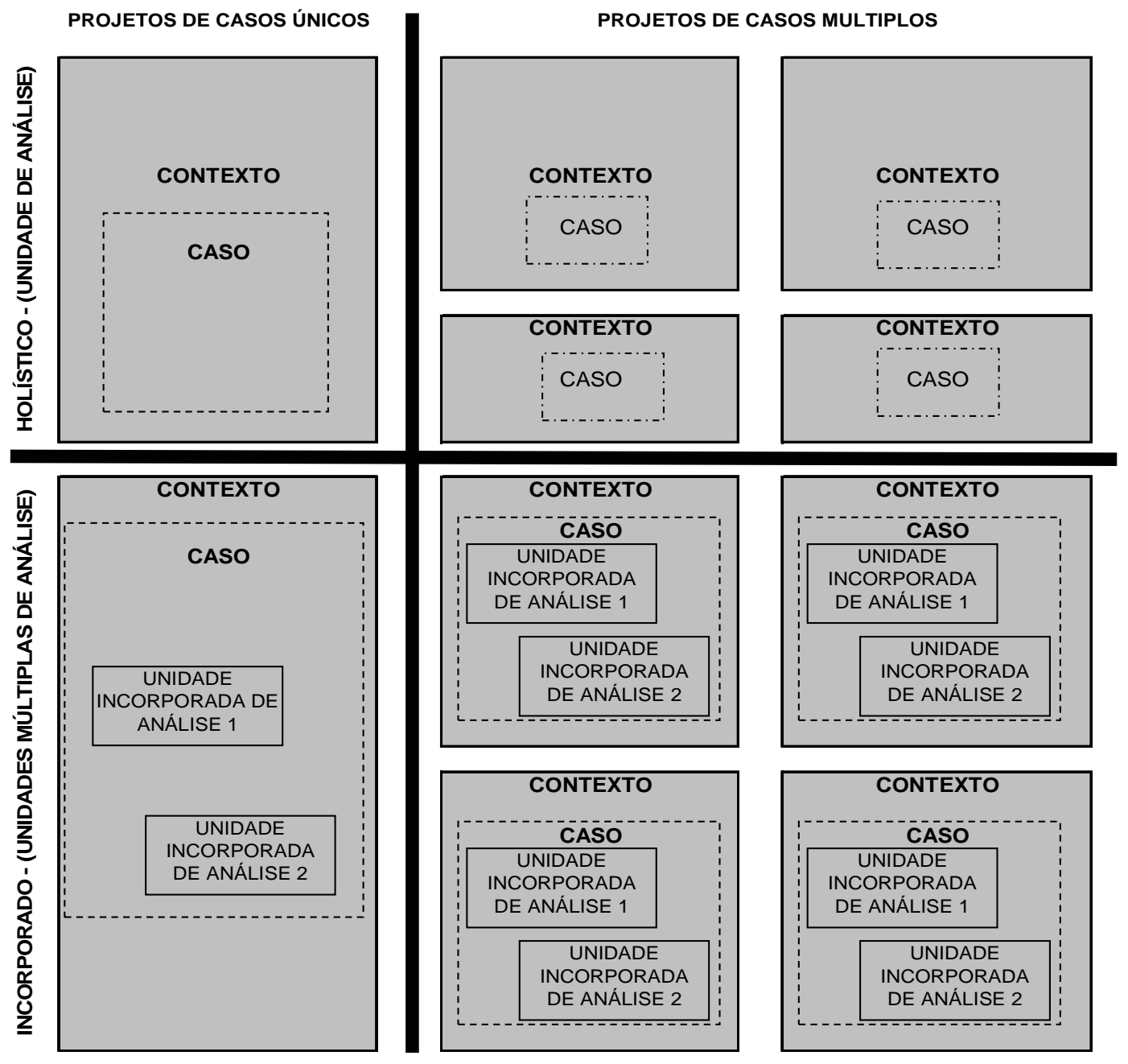

Figura 11. Tipos básicos de projetos de estudo de caso Fonte: COSMOS Corporation citado por Yin (2005, p.61)

Os estudos de caso único devem ser feitos com cuidado, principalmente no tocante às generalizações que são feitas a partir dos mesmos. Além disto, pode-se verificar ao longo do 
estudo que o caso estudado não se constituía na situação que se pensava estudar, podendo assim, não ter adesão à teoria inicialmente proposta (YIN, 2001).

Yin (2005, p. 67) argumenta que o projeto de caso único é eminentemente justificável sob certas condições quando o caso representa: um teste crucial de uma teoria existente; uma circunstância rara ou exclusiva; um caso típico ou representativo; ou quando o caso serve a um propósito revelador ou longitudinal. De acordo com esse autor, a definição da unidade de análise é uma etapa fundamental para se projetar e conduzir um caso único.

Já para os estudos de casos múltiplos, Roesch (1999, p. 200) descreve que eles têm por objetivo a comparação entre unidades distintas estudadas, para permitir aprofundamento na interpretação dos fatos, explicações inerentes e conclusões envolvendo as unidades pesquisadas.

Yin (2005) descreve que para os projetos de casos múltiplos é fundamental utilizar a lógica da replicação, ou seja, após uma descoberta significativa em um primeiro estudo, o objetivo imediato é replicar essa descoberta conduzindo outros estudos.

Para este trabalho, o método utilizado foi o estudo de caso único, pois permite uma investigação para se preservar as características holísticas significativas dos acontecimentos da vida real (Yin, 2005, p. 20).

\subsection{Unidade de análise}

A unidade de análise pode ser um indivíduo, uma decisão, um programa, pode ser sobre a implantação de um processo e sobre uma mudança organizacional, pode ser uma empresa, uma área específica, uma atividade, entidades e outros (YIN, 2005). A definição da unidade de análise está em conformidade com as questões de estudo definidas (LAZZARINI, 1995). 
Devido à dificuldade de encontrar projetos do tipo colaborativo na indústria, com sucesso, optou-se pela estratégia do estudo de caso único e incorporado. Na escolha do caso, procurou-se uma empresa com nível alto de maturidade em gerenciamento do desenvolvimento de produtos, frente o padrão do setor (ver a subseção 6.2.3.) Para este trabalho, a unidade de análise é cada projeto colaborativo de sucesso, em um total de dois, encontrados no caso identificado.

Os projetos foram desenvolvidos por uma IMA localizada no interior do Estado de São Paulo. Um desses projetos foi entre a empresa e um cliente e o outro foi entre a empresa e um fornecedor.

Para entender todo o processo da colaboração desses projetos foi aplicado um roteiro de pesquisa, tendo como respondente o responsável pela área de engenharia de desenvolvimento de produtos da empresa. Por sigilo profissional e acadêmico, neste trabalho a empresa será referenciada como "a empresa estudada".

\subsection{Etapas do trabalho}

Este trabalho apresentou as seguintes etapas descritas na seqüência.

- Pesquisa Bibliográfica: compreendeu pesquisas em livros, dissertações, teses e artigos publicados em revistas especializadas e científicas. Foram efetuadas várias buscas em sites de universidades, de órgãos públicos, de organizações internacionais e entidades de classes.

- Realizacão de contatos com empresas do setor: contatos com empresas produtoras de bens de capital e de máquinas agrícolas. Visita à feira de exposições de máquinas e implementos agrícolas (Agrishow) em Ribeirão Preto, visando, à principio, identificar e posteriormente contatar as empresas 
que atuam ou tenham atuado em projetos colaborativos para o desenvolvimento de produtos.

- Elaboracão do roteiro de pesquisa para o estudo de caso: O roteiro foi confeccionado em forma de um questionário com perguntas do tipo aberta (não estruturadas) e do tipo fechada (escalas: de importância e Likert). Composto por quatro partes: a caracterização da empresa, colaboração na empresa, classificação do projeto e avaliação dos fatores críticos de sucesso.

- Realizacão do estudo de campo: agendamento da entrevista, visita às dependências da empresa estudada e reunião com o Gerente Executivo da Engenharia para efetivação do questionário.

- Compilacão e análise dos resultados: verificação, análise e compilação de todas as anotações feitas no questionário.

Neste capítulo foram apresentadas as premissas que compõem as partes didáticas e técnicas do trabalho. No próximo, serão apresentadas as características da empresa estudada e demais resultados do estudo de caso. 


\section{RESULTADOS}

Este capítulo apresenta os resultados da pesquisa de campo. A seção 6.1 faz uma caracterização geral da empresa estudada, a seção 6.2 descreve a estrutura organizacional, a seção 6.3 a colaboração na empresa, a seção 6.4 o projeto colaborativo com o cliente e a seção 6.5 o projeto colaborativo com o fornecedor.

\subsection{Caracterização da empresa}

A Empresa estudada produz máquinas e implementos agrícolas e está localizada no interior do Estado de São Paulo. Foi fundada há mais de 50 anos, sua administração é familiar e seu controle acionário é de capital fechado.

Em 1975, com a evolução dos negócios da empresa, foi inaugurada mais uma planta industrial que abriga hoje a fundição com forno de indução elétrico, a usinagem de metais e um laboratório de controle da qualidade das peças.

A empresa obteve a certificação ISO 9001 e foi certificada em 2002 da versão 2000. $\mathrm{Na}$ atualidade, exporta para países da América do Norte, da África, Oriente Médio, Oceania, Europa e América Latina.

\subsection{Estrutura organizacional}

A empresa possui 550 funcionários, alocados em quatro áreas ou funções principais, cujos nomes simplificados são: apoio, engenharia, produção e comercial. Por simplificação, entende-se a não utilização do nome formal, empregado pela empresa em questão.

Os setores de responsabilidade de cada área e o número total de funcionários por área são representados pelo quadro 6 . 


\begin{tabular}{|c|c|c|}
\hline ÁREAS & \multicolumn{2}{|c|}{ SETORES DE ATIVIDADES/FUNCIONÁRIOS } \\
\hline $\begin{array}{l}.0 \\
\frac{0}{2} \\
\frac{0}{2}\end{array}$ & $\begin{array}{c}\text { Financeiro } \\
\text { Jurídico } \\
\text { Recursos Humanos } \\
\text { Tecnologia da Informação }\end{array}$ & 50 \\
\hline 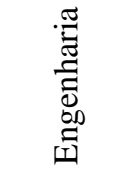 & $\begin{array}{c}\text { Controle da Qualidade } \\
\text { Gerencia de Projetos } \\
\text { Desenvolvimento e Tecnologia } \\
\text { Engenharia de Processos e Produtos }\end{array}$ & 55 \\
\hline 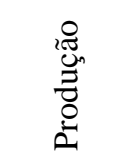 & $\begin{array}{c}\text { Logística } \\
\text { Planejamento e Controle da } \\
\text { Produção } \\
\text { Suprimentos }\end{array}$ & 400 \\
\hline 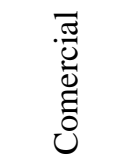 & $\begin{array}{l}\text { Assistência Técnica } \\
\text { Marketing } \\
\text { Vendas }\end{array}$ & 45 \\
\hline
\end{tabular}

Quadro 6. Setores de atividades e número total de funcionários por área (desenvolvido pelo autor) 
A área de engenharia apresenta uma estrutura matricial (figura 12).

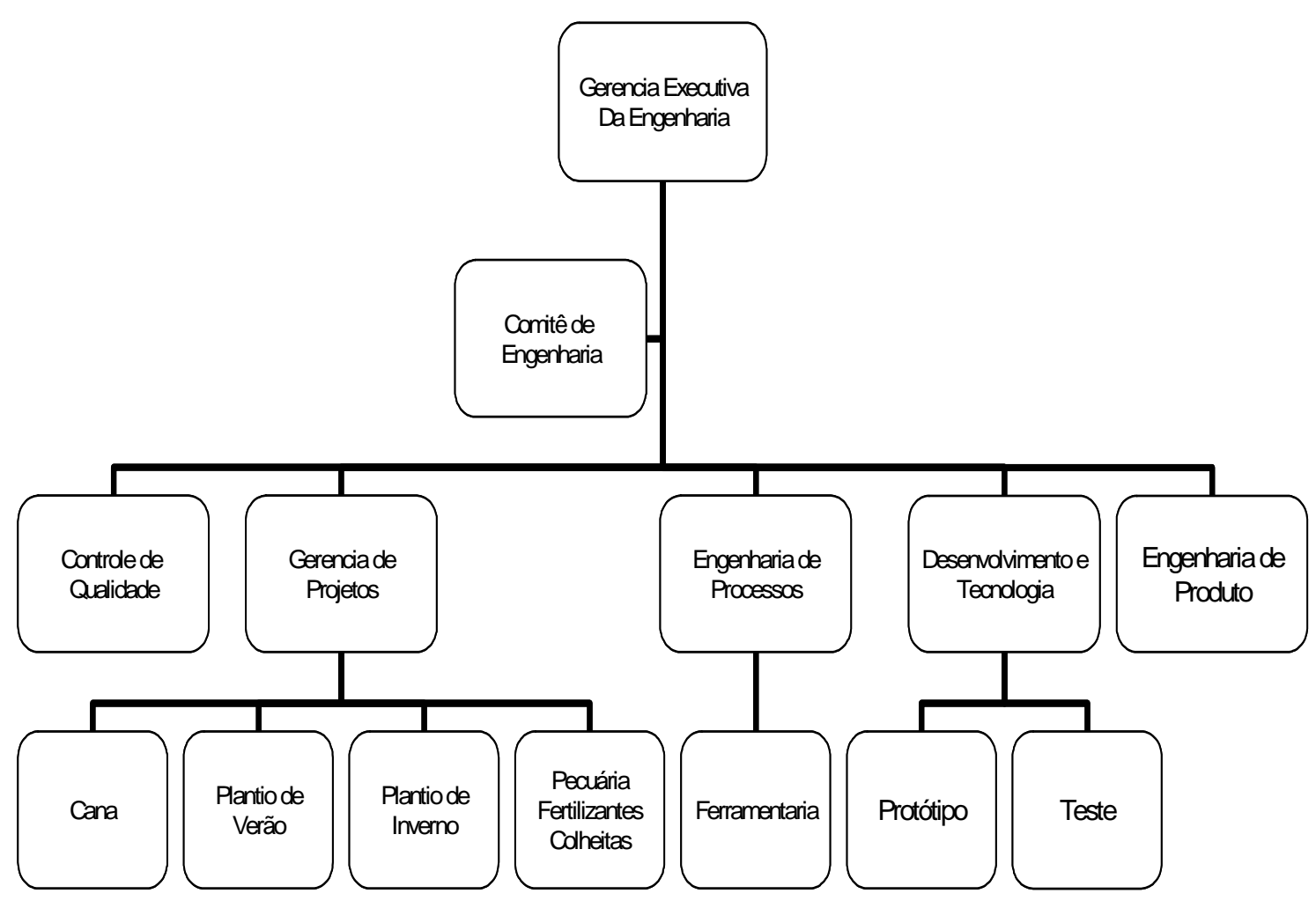

Figura 12. Organograma da área de engenharia da empresa estudada (desenvolvida pelo autor conforme informações fornecidas pela empresa)

$\mathrm{Na}$ área da engenharia, o número total de funcionários é 55, assim distribuídos:

- 1 engenheiro de produção que ocupa o cargo de gerente executivo da engenharia.

- 4 gerentes de projetos - desenvolvimento de produtos para cana, plantio de verão e inverno, pecuária, fertilizantes e colheitas.

- 8 projetistas de produtos alocados no setor de engenharia de produto. 
- 5 projetistas de processos alocados no setor de engenharia de processos.

- 6 funcionários no setor de desenvolvimento e tecnologia (protótipos e testes).

- 10 funcionários no setor de controle da qualidade.

- 06 funcionários no setor de ferramentaria.

Os demais funcionários (15) são alocados nos projetos de desenvolvimento de produtos para cana, plantio de verão e inverno, pecuária, fertilizantes e colheitas.

A empresa possui ainda um comitê, aqui chamado de Comitê de Engenharia, que é formado pelo gerente executivo da engenharia, pelos líderes das respectivas gerências de projetos e gerentes funcionais da engenharia de produtos, engenharia de processos, desenvolvimento e tecnologia, além do coordenador do escritório de projetos e tem por objetivo discutir e acrescentar melhorias no processo de desenvolvimento de produtos e assessorar os gerentes de projetos e gerentes funcionais na tomada de decisões durante o PDP.

\subsubsection{Descrição dos produtos}

A empresa produz e comercializa uma variada família de produtos para as atividades agrícola e pecuária, assim distribuída:

- Distribuidores de fertilizantes.

- Máquinas e implementos para a adubação, plantio e cultivo de culturas agrícolas.

- Implementos para a linha canavieira e pecuária.

A linha principal, com maior quantidade de produtos, é a linha para plantio, onde se encontram as máquinas do tipo plantadeira.

\subsubsection{Tipos de projetos de desenvolvimento de produtos}


Nos últimos cinco anos, segundo o principal executivo da área de engenharia foram identificados onze projetos de desenvolvimento de produtos (gráfico 5). Esses projetos foram distribuídos de acordo com a tipologia informada na seção 1.3 (tipos de desenvolvimento de produtos) do roteiro de pesquisa.

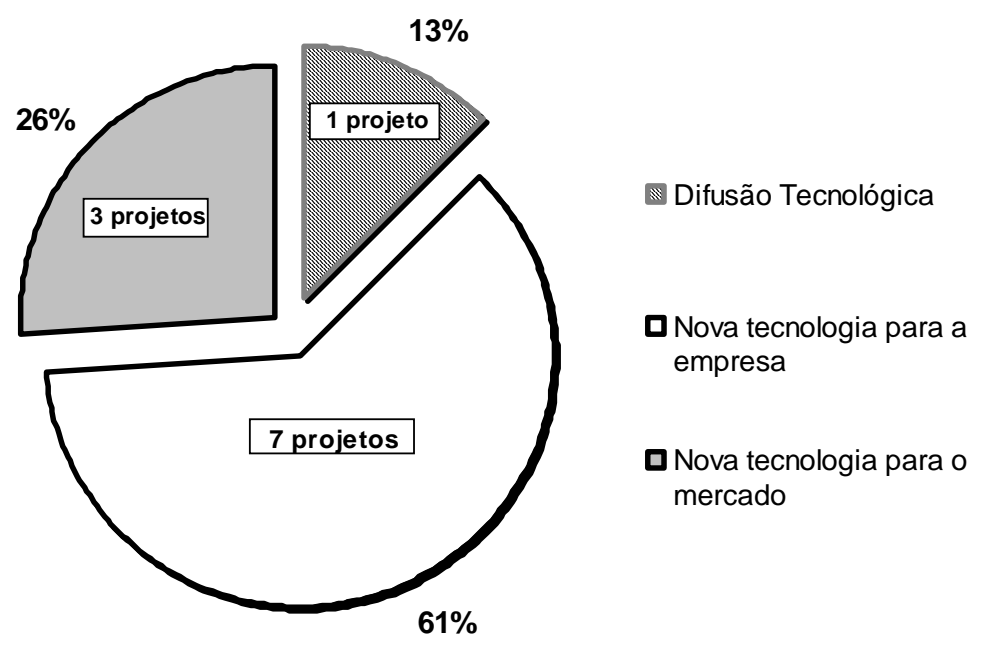

Gráfico 5. Tipos de projetos de desenvolvimento de produtos da empresa estudada (desenvolvida pelo autor)

\subsubsection{Nível de maturidade do PDP}

Um dos principais aspectos para este estudo é verificar o nível de maturidade em desenvolvimento de produto, comparando-a com o padrão da indústria. Para tal, empregou-se o trabalho de Simões (2007), descrito na subseção 2.5 desta dissertação.

Conforme descrito, a pesquisa realizada pela autora fez uma classificação das pequenas e médias empresas da IMA, identificando 3 grupos por nível de maturidade do Processo de Desenvolvimento de Produto. O grupo mais evoluído possui as características demonstradas no quadro 7, apresentadas ao lado das características da empresa estudada. 


\begin{tabular}{|c|c|c|}
\hline Características & $\begin{array}{c}\text { Situação das empresas do } \\
\text { Grupo } 3 \text { (maior nível de } \\
\text { maturidade), segundo Simões } \\
\text { (2007) }\end{array}$ & Situação da Empresa Estudada \\
\hline $\begin{array}{l}\% \text { de empresas que conhecem o } \\
\text { conceito de gestão de portfólio }\end{array}$ & $50 \%$ & $\begin{array}{c}\text { A empresa não apenas conhece mas utiliza e } \\
\text { possui a Gestão de Portfólio formalizada no } \\
\text { SGQ. } \\
\text { Utiliza critérios }\end{array}$ \\
\hline $\begin{array}{l}\text { \% de empresas que realizam, de } \\
\text { maneira formal, pesquisa de } \\
\text { mercado }\end{array}$ & $83,30 \%$ & $\begin{array}{c}\text { Realiza pesquisa de mercado por meio de } \\
\text { sua rede de vendedores e assistência } \\
\text { técnica. } \\
\text { Está formalizado no seu SGQ. }\end{array}$ \\
\hline $\begin{array}{l}\% \text { de empresas que utilizam } \\
\text { indicadores para avaliar o } \\
\text { desempenho do PDP no todo }\end{array}$ & $17 \%$ & $\begin{array}{l}\text { Programa de avaliação desempenho do } \\
\text { PDP: } \\
\text { Tempo decorrido x \% de tarefas realizadas, } \\
\text { Indicadores de custo e qualidade }\end{array}$ \\
\hline $\begin{array}{l}\text { Principais tipos de parceiros } \\
\text { existentes ao longo do PDP }\end{array}$ & $\begin{array}{l}\text { Fornecedores, clientes usuários } \\
\text { finais, universidades }\end{array}$ & $\begin{array}{c}\text { Fornecedores, clientes, empresas de } \\
\text { consultoria, universidades, centros de } \\
\text { formação profissional }\end{array}$ \\
\hline $\begin{array}{l}\text { \% de empresas que possuem algum } \\
\text { mecanismo formal para registrar } \\
\text { experiências passadas/ lições } \\
\text { aprendidas dos projetos de DP } \\
\text { realizados }\end{array}$ & $42 \%$ & $\begin{array}{l}\text { Não há um mecanismo formal para registrar } \\
\text { as experiências passadas e lições aprendidas }\end{array}$ \\
\hline $\begin{array}{l}\text { Principais ferramentas /métodos de } \\
\text { apoio ao PDP utilizados pelas } \\
\text { empresas }\end{array}$ & CAD e Benchmarking & $\begin{array}{c}\text { CAD 3D } \\
\text { Ferramentas de análise estrutural (CAE) } \\
\text { Instrumentação dinâmica na área de } \\
\text { Engenharia Avançada / Testes }\end{array}$ \\
\hline $\begin{array}{l}\text { Realização das atividades da macro } \\
\text { fase de pré-desenvolvimento }\end{array}$ & $\begin{array}{l}3 \% \text { não realiza } \\
35 \% \text { informal } \\
63 \% \text { formal }\end{array}$ & formalizado \\
\hline $\begin{array}{l}\text { Realização das atividades da macro } \\
\text { fase de desenvolvimento }\end{array}$ & $\begin{array}{l}6 \% \text { não realiza } \\
14 \% \text { informal } \\
80 \% \text { formal }\end{array}$ & formalizado \\
\hline $\begin{array}{l}\text { Realização das atividades da macro } \\
\text { fase de pós-desenvolvimento }\end{array}$ & $\begin{array}{l}25 \% \text { não realiza } \\
19 \% \text { informal } \\
56 \% \text { formal }\end{array}$ & Não realiza \\
\hline $\begin{array}{l}\text { A quem o DP responde na empresa } \\
\text { principalmente }\end{array}$ & $\begin{array}{c}\text { Área própria da empresa vinculada } \\
\text { à } \\
\text { Presidência / diretoria ou setor } \\
\text { vinculado à } \\
\text { Indústria / produção } \\
\end{array}$ & $\begin{array}{l}\text { Área própria da empresa vinculada à } \\
\text { Presidência / diretoria ou setor vinculado à } \\
\text { Indústria / produção }\end{array}$ \\
\hline Arranjo organizacional adotado & Matricial & Matricial \\
\hline $\begin{array}{l}\mathrm{N}^{\circ} \text { médio de funcionários que } \\
\text { fazem parte diretamente da área de } \\
\text { DP }\end{array}$ & 9,4 funcionários & 8 funcionários \\
\hline $\begin{array}{l}\mathrm{N}^{\circ} \text { médio de projetos conduzidos } \\
\text { simultaneamente na empresa }\end{array}$ & 5,3 projetos & 11 projetos nos últimos 5 anos \\
\hline Exportação & $83 \%$ & $\begin{array}{l}\text { Exporta para vários países } \\
\text { (ver seção 6.1. caracterização da empresa) }\end{array}$ \\
\hline Certificação & $25 \%$ & Certificada ISO 9001 \\
\hline
\end{tabular}




\begin{tabular}{|c|c|c|}
\hline $\begin{array}{l}\% \text { de empresas que possuem um } \\
\text { procedimento } \\
\text { formalizado/documentado que } \\
\text { define as atividades do PDP }\end{array}$ & $58 \%$ & $\begin{array}{l}\text { PDP formalizado, desde a escolha dos } \\
\text { projetos até o lançamento do produto }\end{array}$ \\
\hline $\begin{array}{l}\% \text { de empresas que realizam } \\
\text { reuniões de avaliação das atividades } \\
\text { realizadas durante o PDP }\end{array}$ & $\begin{array}{l}50 \% \text { informal } \\
50 \% \text { formal }\end{array}$ & $\begin{array}{l}\text { Formalizado em documento próprio da } \\
\text { engenharia }\end{array}$ \\
\hline $\begin{array}{l}\text { Quantidade de fases do PDP em que } \\
\text { estas parcerias ocorrem }\end{array}$ & 6 fases & 5 fases \\
\hline $\begin{array}{l}\mathrm{N}^{\circ} \text { médio de funcionários que } \\
\text { participam de cada equipe }\end{array}$ & 6,9 funcionários & Dado indisponível \\
\hline $\begin{array}{l}\mathrm{N}^{\circ} \text { médio de funcionários com } \\
\text { formação superior na área de DP }\end{array}$ & $\begin{array}{l}\text { 2,9 funcionários } \\
(31 \%)\end{array}$ & Dado indisponível \\
\hline $\begin{array}{l}\mathrm{N}^{\circ} \text { médio de equipes que trabalham } \\
\text { simultaneamente na empresa }\end{array}$ & 1,5 equipes & Dado indisponível \\
\hline Escritório de Projetos & Dado indisponível & $\begin{array}{c}\text { Conceito introduzido na empresa em } 2005 \text {, } \\
\text { Há um coordenador com dedicação } \\
\text { exclusiva }\end{array}$ \\
\hline
\end{tabular}

Quadro 7. Comparação do nível de maturidade da empresa estudada (com o levantamento realizado por Simões,2007).

Analisando o quadro 7, é possível perceber que a empresa possui a maioria das características das empresas do grupo 3, segundo o perfil identificado por Simões(2007). Trata-se de uma empresa com uma estrutura dedicada ao desenvolvimento de produto e com um processo sistematizado por fases, procedimentos e com um avançado procedimento de gestão de portfólio. Possui equipes de projeto e conta até mesmo com um escritório de projetos. O PDP é avaliado por meio de indicadores de desempenho e possui uma sistemática de reuniões permitindo a integração das equipes de projeto.

\subsection{Colaboração na empresa}

A empresa reconhece a importância da colaboração em desenvolvimento de produtos e procura incentivá-la. Possui casos de colaboração com diferentes agentes tais como os 
clientes, fornecedores, universidades, centros de capacitação profissional. Em relação à colaboração com os clientes, os principais objetivos destacados são: a pesquisa e desenvolvimento de produtos, ensaios e testes, a coleta de informações e benchmarking.

No caso da colaboração com os fornecedores, os principais objetivos são: pesquisa e desenvolvimento de produtos e a assistência técnica durante o projeto, sendo os ensaios e testes menos freqüentes.

Já com as universidades, os principais objetivos são: a pesquisa e desenvolvimento de produtos, o treinamento, ensaios e testes, a assistência técnica é um objetivo com pouca freqüência.

Com os centros de capacitação profissional o objetivo principal é o treinamento. Há experiências mais pontuais com outros agentes como empresas de consultorias. Nestes casos, considerados de baixa importância, o objeto da colaboração foi a coleta de informações, benchmarking e uma para serviços de detalhamento de engenharia.

O quadro 8 resume as informações. Está dividido em dois blocos. Um contendo os níveis de importância e o outro os objetivos da colaboração entre a empresa e demais organizações. 


\begin{tabular}{|c|c|c|c|c|c|c|c|c|c|c|}
\hline \multirow[b]{2}{*}{ Parceiro } & \multicolumn{4}{|c|}{ Importância } & \multicolumn{6}{|c|}{ Objetivo da colaboração } \\
\hline & $\underset{\approx}{\stackrel{D}{*}}$ & $\underset{2}{2}$ & 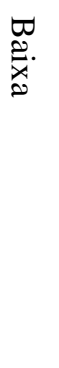 & 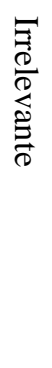 & 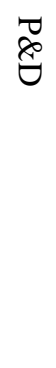 & 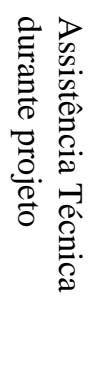 & 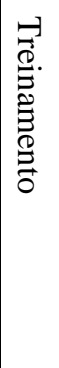 & 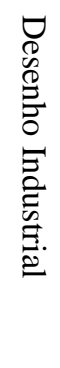 & 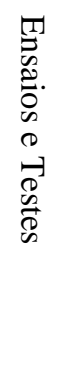 & 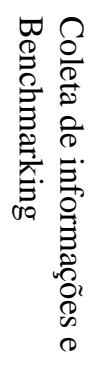 \\
\hline Clientes & & & & & & & & & & \\
\hline Fornecedores & & & & & & & & & $*$ & \\
\hline Empresas do grupo & & & & & & & & & & \\
\hline Empresas de consultoria & & & & & & & & * & & \\
\hline Universidade e institutos de pesquisa & & & & & & $*$ & & & & \\
\hline $\begin{array}{l}\text { Centros de capacitação profissional e } \\
\text { assistência técnica (SENAI e Núcleos } \\
\text { afins) }\end{array}$ & & & & & & & & & & \\
\hline
\end{tabular}

(*) com pouca freqüência

Quadro 8. Os objetivos da colaboração entre a empresa e demais organizações (desenvolvida pelo autor).

As motivações apontadas pela empresa para a realização dessas parcerias são descritas nos itens a seguir:

- habilidade e conhecimento do cliente: nesse setor de atuação há clientes que possuem habilidades e conhecimentos técnicos avançados. Por isso, é comum o desenvolvimento colaborativo com eles. Em alguns casos apóiam o desenvolvimento, sugerindo alterações em máquinas ou mesmo assumindo riscos como no caso da compra de protótipos ou permitindo que as máquinas sejam testadas em suas áreas produtivas.

- Acesso a testes dos produtos: a colaboração com os clientes, produtores rurais, é importante também para a empresa ter acesso a testes mais realistas dos equipamentos. 
- Conhecimentos complementares: algumas tecnologias que não fazem parte da competência essencial da empresa. Por exemplo, pode-se citar a parte hidráulica e transmissão das máquinas, onde a empresa desenvolve o conceito e faz o dimensionamento do sistema em conjunto com o fornecedor.

- Falta de recursos humanos internos especializados: Há momentos de sobrecarga de trabalho de desenvolvimento que é solucionada com a subcontratação de serviços especializados de engenharia, proporcionando intercâmbio de informações e competências.

\subsection{Projeto colaborativo com o cliente}

O primeiro projeto a ser descrito foi realizado entre a empresa estudada e um cliente. O resultado foi o desenvolvimento colaborativo de uma máquina plantadora de grãos.

\subsubsection{Surgimento da parceria e motivação}

A parceria surgiu quando o cliente, um proprietário de fazendas com elevado interesse e vários anos de experiência com máquinas agrícolas, consultou a empresa e expôs uma necessidade especial. $\mathrm{Na}$ verdade, além da necessidade, o cliente havia conjeturado algumas possíveis soluções técnicas em um dos produtos da empresa, visando solucioná-lo. Os técnicos da área de desenvolvimento estudaram o problema e identificaram o potencial para a criação de um novo produto, com inovação significativa, mais do que alterar o produto que a empresa já possuía.

A nova idéia foi analisada do ponto de vista de seu potencial de mercado. Fez-se uma pesquisa simples, com outros clientes da empresa cujo perfil os incluía como potenciais usuários do novo produto. O resultado foi a identificação do interesse em adquirir o produto, caso fosse desenvolvido em escala para o mercado consumidor. Demonstrou-se, assim, de 
maneira simples, o potencial do produto. Diante deste cenário promissor, a empresa propôs um projeto em colaboração junto com o cliente. No acordo, a empresa se encarregaria de detalhar e desenvolver cinco protótipos que seriam montados, testados e custeados pelo cliente, era o início do ano de 2001. Em contrapartida, o cliente acompanharia o desenvolvimento, avaliando as soluções técnicas e pagaria apenas o custo de fabricação dos protótipos. O projeto durou um ano e meio e o produto final foi lançado no mercado em 2002.

\subsubsection{Classificação do projeto e contribuição}

O projeto pode ser considerado como uma nova tecnologia para o mercado, segundo a tipologia apresentada no referencial teórico (ver a seção 3.1. classificação do projeto, no roteiro de pesquisa). O principal diferencial que o distingue como uma grande inovação frente aos produtos da época foi uma versatilidade maior de acessórios e implementos que podem ser instalados. Tornou o equipamento mais flexível e permitia maior aproveitamento na fazenda, gerando economias ao produtor rural.

Tal flexibilidade foi possível devido à utilização de uma nova concepção do produto, com significativa diferença frente a adotada regularmente nas máquinas presentes no mercado da época, inclusive, em termos mundiais. Esta máquina plantadora de grãos possui um sistema pantográfico próprio para terrenos com topografias irregulares.

Portanto, os principais objetivos da colaboração foram: a coleta de informações; as pesquisas e desenvolvimento; e ensaios e testes.

O projeto foi desenvolvido por uma equipe composta de cinco profissionais entre projetistas e técnicos que trabalharam em tempo integral durante o período de um ano e meio na propriedade do cliente, localizada na Bahia.

Durante o projeto foram realizadas várias reuniões de trabalho com o cliente e também na sede da empresa, formalizadas em documentação padrão da engenharia. A 
comunicação utilizada entre a equipe alocada com o cliente e com a sede da empresa era por intermédio de telefone e fax.

\subsubsection{Avaliação dos fatores críticos}

O respondente discorreu sobre cada um dos fatores críticos conforme o roteiro de entrevistas presente no apêndice A (a questão 4.1. do roteiro de pesquisa contém a lista dos FCS por área e um conjunto de perguntas fechadas tipo "escala de Likert"). Assim, ele emitiu parecer sobre a presença de cada um dos fatores no projeto, justificando e comentando suas respostas. Os pareceres do respondente foram tabulados e os resultados agrupados em uma escala qualitativa de importância nos gráficos apresentados na seqüência.

O gráfico 6 sumariza os resultados dos FCS relacionados com a área de Gerenciamento de Projeto. Analisando-o, é possível perceber que os FCS "objetivos definidos", "planos acordados mutuamente", "recursos adequados", "monitoramento regular" e "comunicação entre as equipes" apresentaram de uma forma geral um resultado esperado, segundo o respondente. As partes reuniam-se periodicamente para averiguar, analisar e corrigir desvios.

Porém, o respondente fez ressalvas quanto a dois FCS. Os objetivos realistas precisaram ser reformulados no meio do projeto e os marcos (milestones) não foram caracterizados no início do projeto. 


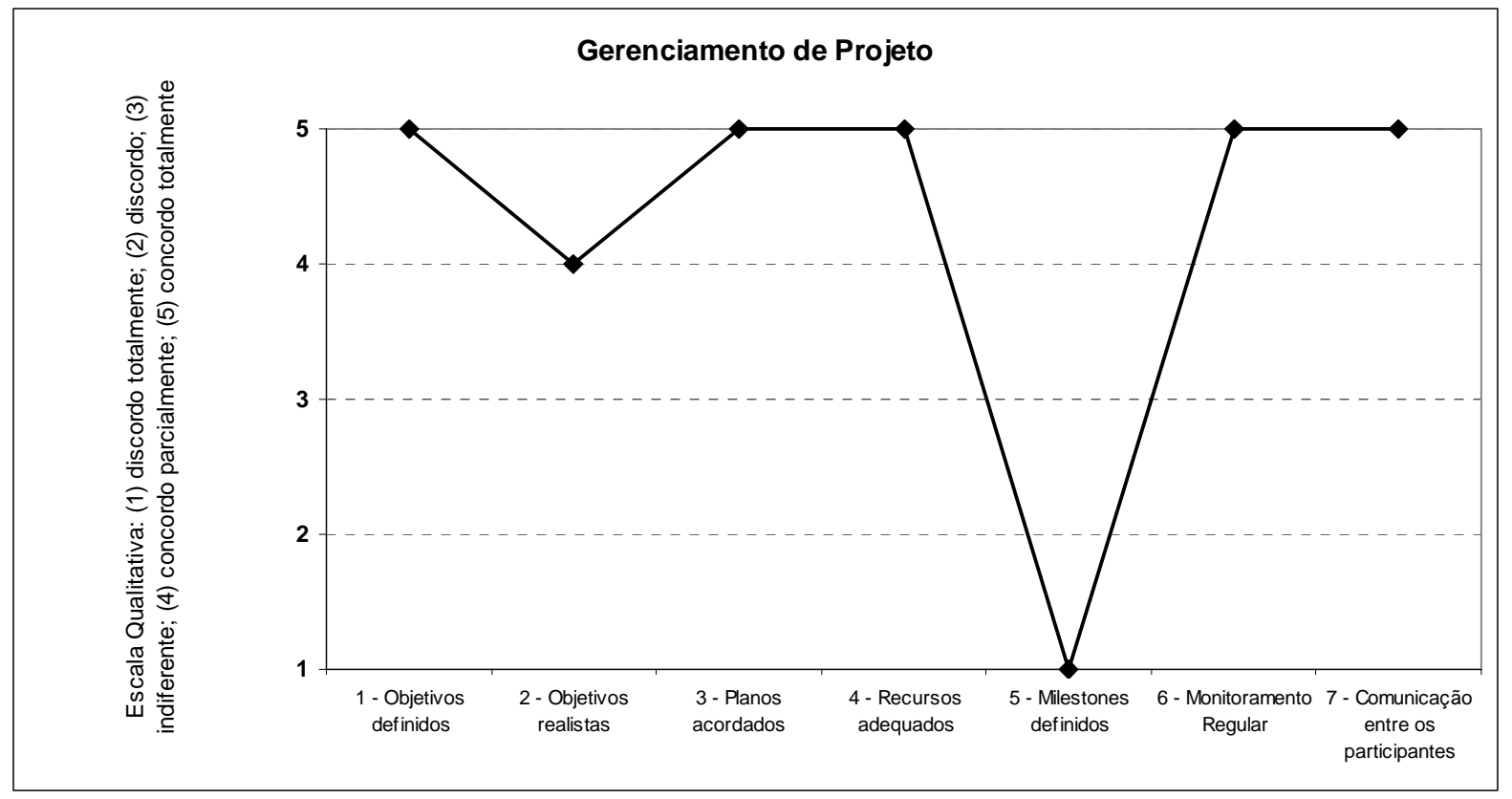

Gráfico 6. FCS da área Gerenciamento de Projeto no projeto com o cliente

Os FCS da área Fatores Universais de Sucesso têm os resultados apresentados no gráfico 7. O respondente citou que o bom relacionamento pessoal do cliente com a direção da empresa estudada proporcionou um grau de confiança e comprometimento acima da média. A participação e incentivo da direção da empresa no projeto foram relativos. Outro aspecto comentado pelo respondente, e que favoreceu o projeto, foi à continuidade das equipes. Isso também influenciou diretamente para que os resultados fossem alcançados. Argumentou, porém, que em virtude do vínculo de amizade entre os parceiros, algumas ações relacionadas às atividades do projeto foram mais verbalizadas e pouco planejadas, deixando as equipes indecisas na hora de priorizar os trabalhos.

O respondente finalizou este bloco de argüições dizendo que o aprendizado não foi documentado como deveria, perdendo-se lições aprendidas sem um registro formal dos fatos. 


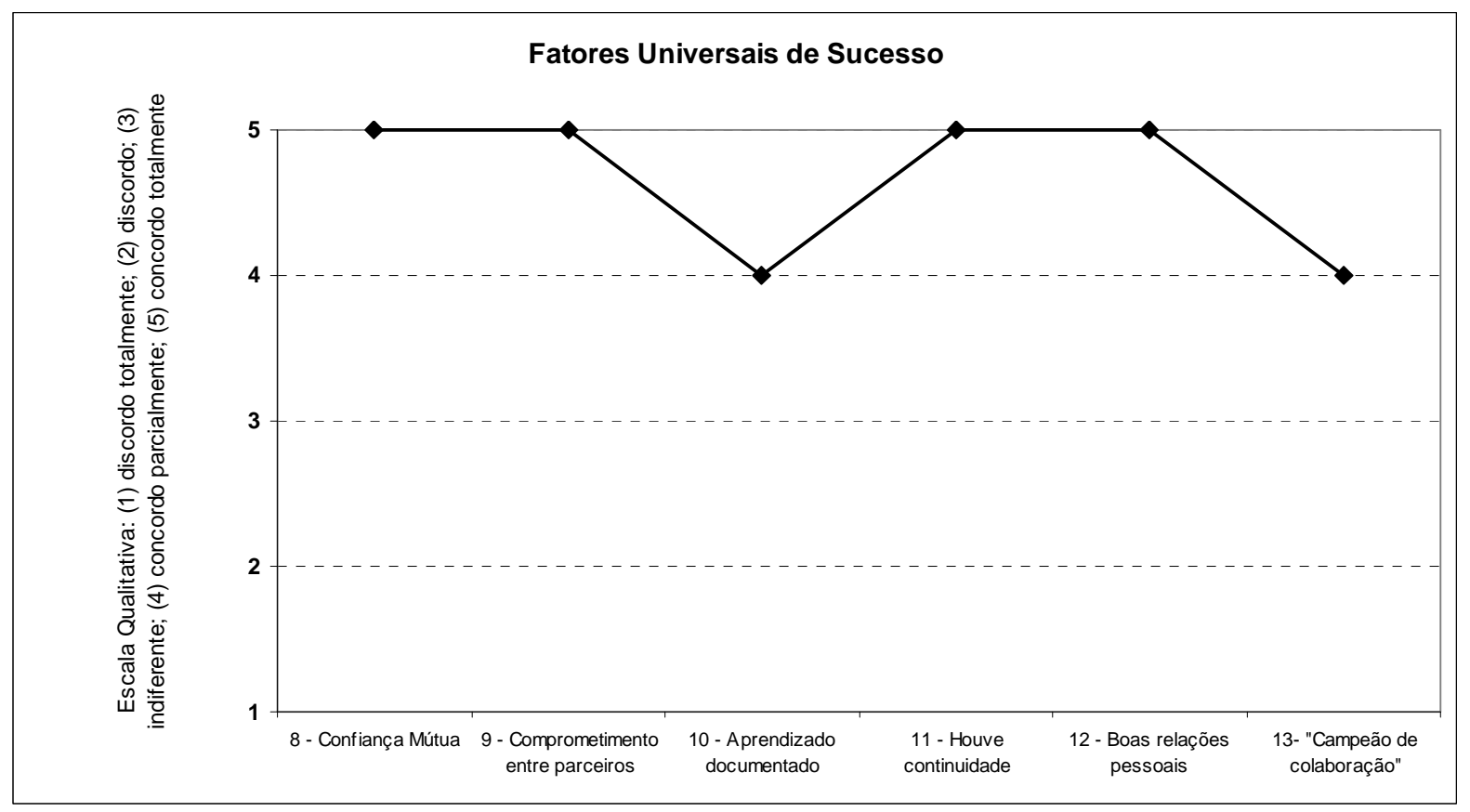

Gráfico 7. FCS da área Fatores Universais de Sucesso no projeto com o cliente

O gráfico 8 apresenta os resultados da área Gerente do Projeto. Para este conjunto de FCS o respondente argumentou que apesar do gerente responsável pelo projeto ter amplos conhecimentos das atividades da empresa, ser um bom negociador e possuir competência técnica, ainda não havia participado de projeto colaborativo. No início houve instabilidade em relação à priorização de ações e a forma de gerenciar. Esse nível de maturidade foi sendo melhorado no transcorrer do projeto, ou seja, o gerente do projeto foi ganhando experiência prática no andamento das atividades. 


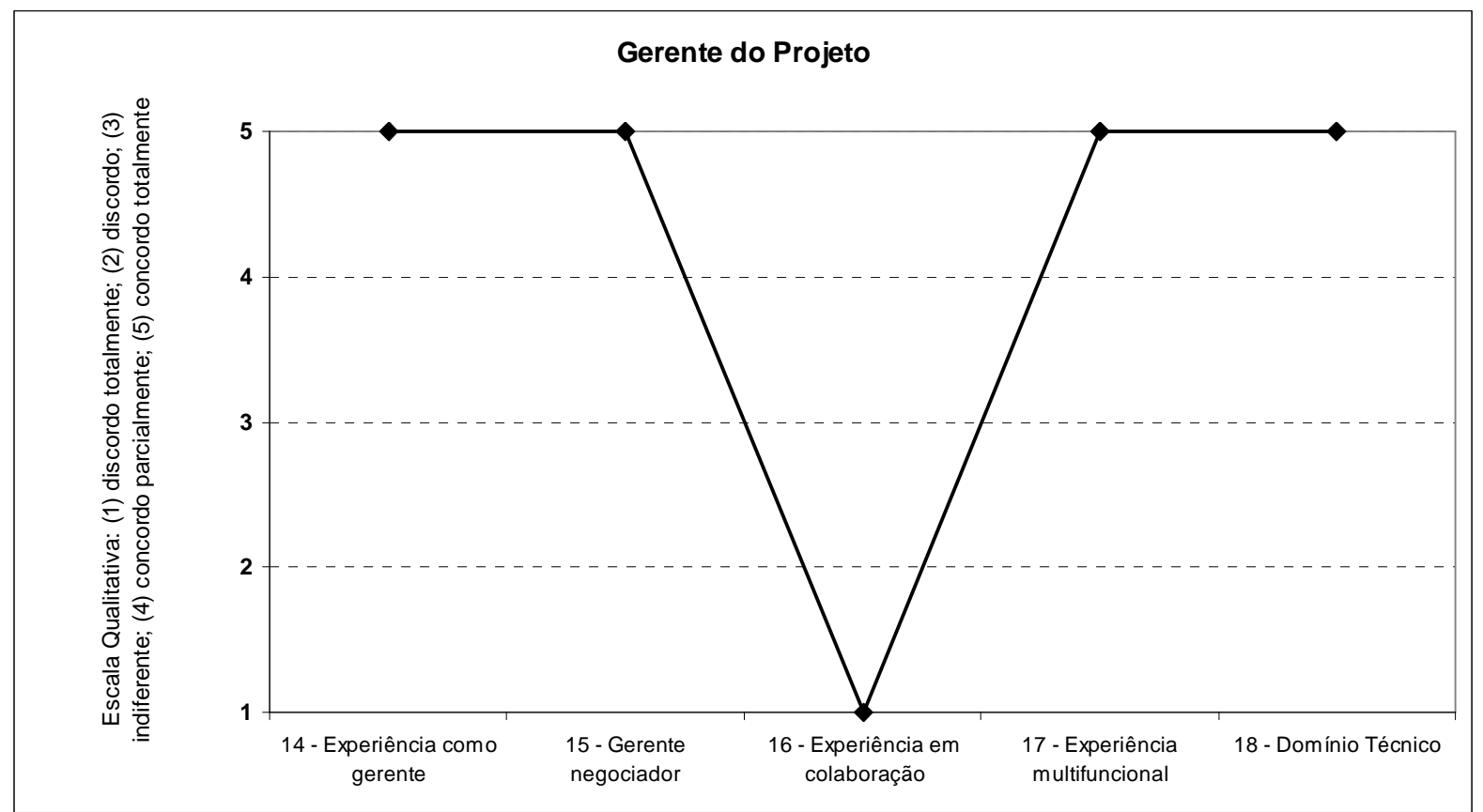

Gráfico 8. FCS da área Gerente do Projeto no projeto com o cliente

Para a área de FCS correspondente a Avaliação do Parceiro (gráfico 9), o respondente reforçou que a afinidade existente entre as partes foi um facilitador que favoreceu todo o ciclo de vida do projeto. Completou dizendo que a iniciativa do cliente em custear os protótipos, assumindo assim um risco futuro de insucesso do produto, proporcionou à empresa estudada um desafio no sentido de gerar novos conhecimentos tecnológicos.

O respondente disse ainda que em nenhum momento durante o projeto, o cliente omitiu algum tipo de informação ou outro objetivo senão aqueles acordados durante as reuniões de trabalho, mostrando-se muito assertivo e com disposição para a colaboração. No encerramento dos comentários sobre essa área, o respondente disse que anteriormente não havia ocorrido qualquer outro vínculo entre a empresa estudada e esse cliente, a não ser compromissos comerciais de compra e venda. Afirmou também que provavelmente o cliente já havia desenvolvido projetos em colaboração com outras empresas, não tendo sido possível para o pesquisador confirmar essa informação. 


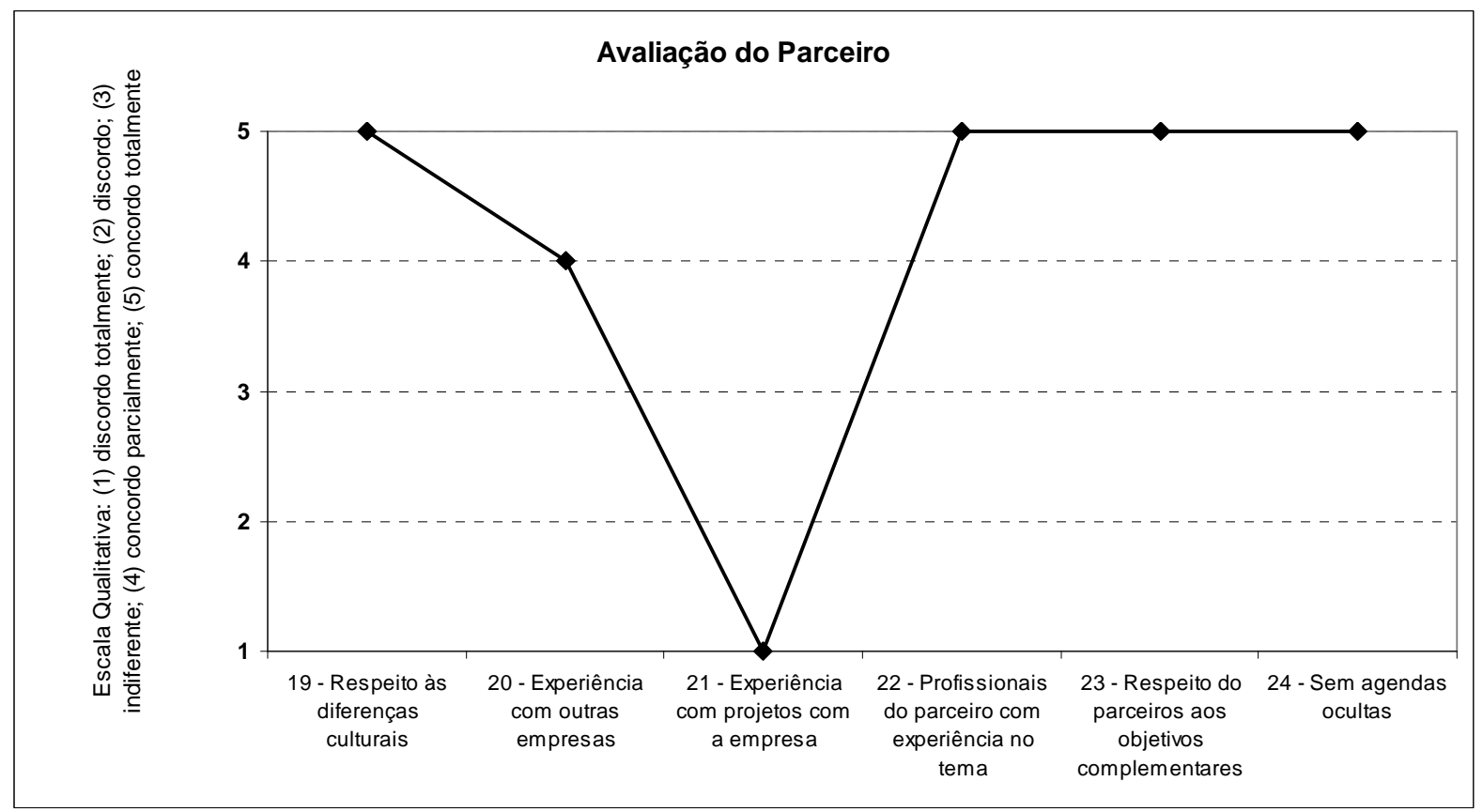

Gráfico 9. FCS da área Avaliação do Parceiro no projeto com o cliente

Em relação às áreas de Garantia de Igualdade (gráfico 10) e Influências do Ambiente (gráfico 11), o respondente argumenta que o resultado desta colaboração proporcionou novos conhecimentos da parte agrícola para a empresa estudada, o produto foi lançado com sucesso, pois, durante as pesquisas efetuadas, ficou constatado que havia um mercado latente para adquiri-lo.

Segundo o respondente, o novo produto ajudou a melhorar a produtividade do cliente com ganhos de escala. A solidez e as políticas da empresa estudada também foram fatores importantes para que o projeto não fosse adiado, paralisado ou então cancelado. 


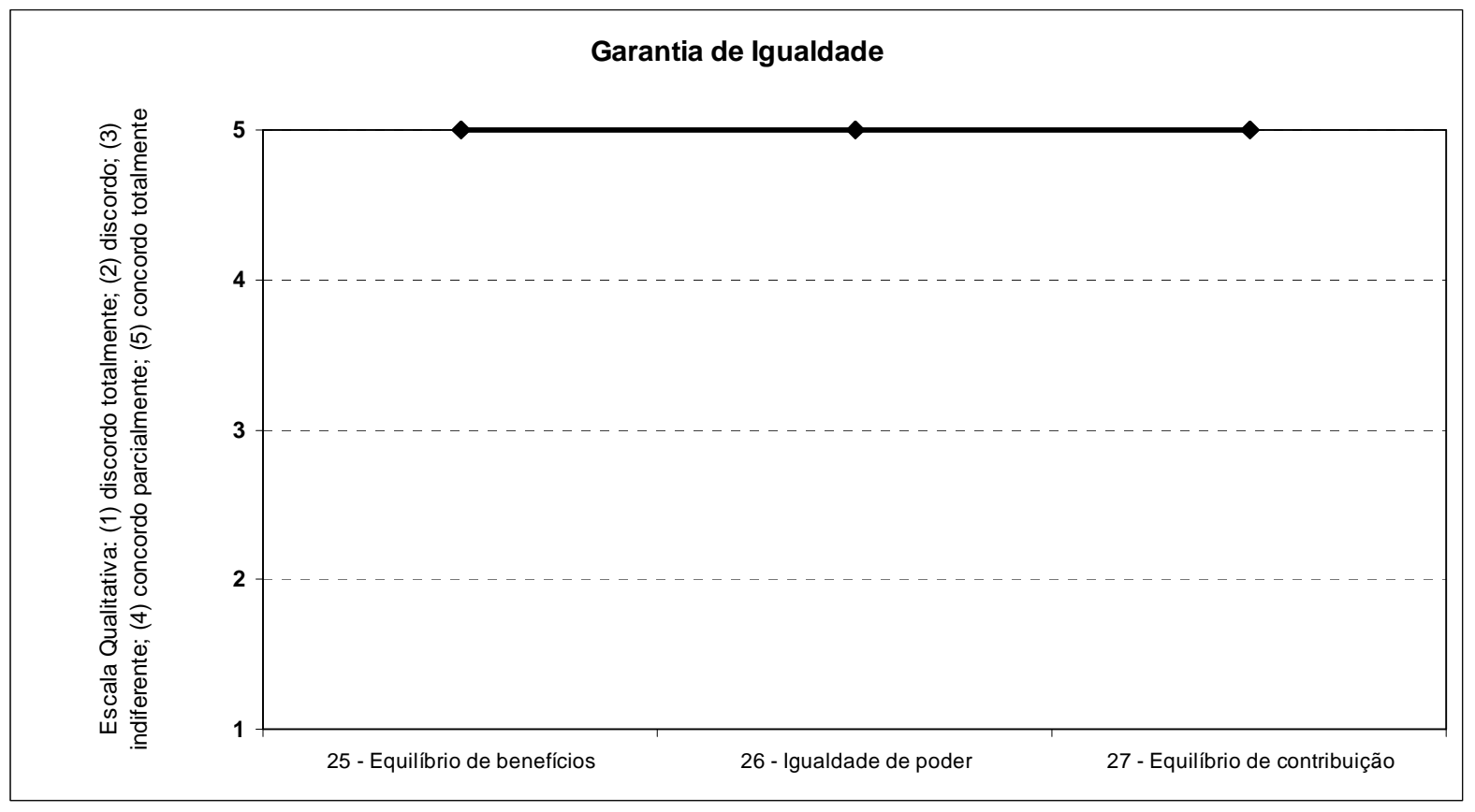

Gráfico 10. FCS da área Garantia de Igualdade no projeto com o cliente

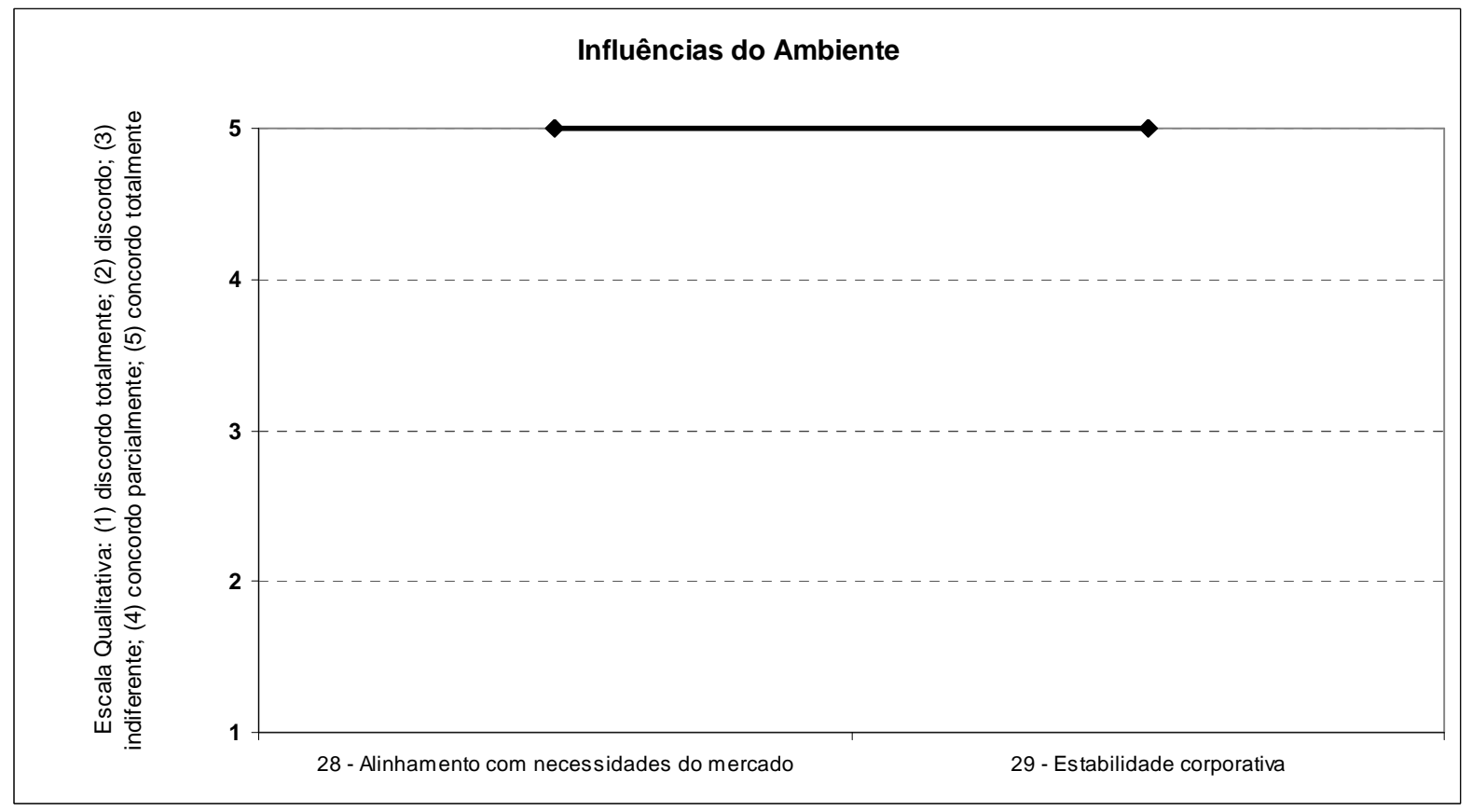

Gráfico 11. FCS da área Influências do Ambiente no projeto com o cliente

Em relação à área Gerenciamento de Riscos no Projeto, o respondente informou que em nenhum momento os parceiros fizeram uso de ferramentas que pudessem auxiliá-los na 
identificação, administração ou até na minimização de qualquer tipo de riscos que poderia surgir durante o ciclo de vida do projeto.

Como resultado final tem-se, portanto, que os principais FCS observados por área foram:

- gerenciamento do projeto: objetivos do projeto definidos claramente; planos do projeto foram acordados mutuamente; recursos foram adequados; houve monitoramento regular do projeto; a comunicação entre os participantes do projeto foi feita de forma eficaz;

- fatores universais de sucesso: houve confiança mútua e comprometimento entre os parceiros; continuidade das pessoas e boas relações pessoais entre os parceiros;

- gerente do projeto: tinha conhecimentos técnicos no tema do projeto; experiência multifuncional e em gerenciamento de projeto; era um bom negociador;

- avaliacão do parceiro: houve respeito das diferenças culturais entre os parceiros; os profissionais do parceiro possuíam experiência no tema do projeto; parceiro conhecia e respeitava os objetivos complementares da outra parte além dos objetivos comuns, o parceiro (cliente) não fazia uso de agendas ocultas, isto é, objetivos não revelados durante projeto;

- garantia de igualdade: equilíbrio nos benefícios, na contribuição e igualdade de poder entre os parceiros do projeto.

- influências do ambiente: o projeto contribuiu para as necessidades do mercado; houve estabilidade corporativa durante o projeto.

Os FCS não observados durante o projeto foram: 
- relacionados ao gerenciamento do projeto: as etapas parciais (milestones) não foram definidas no início do projeto;

- relacionados ao gerente do projeto: sem experiência em colaboração;

- relacionados a avaliação do parceiro: o parceiro não havia trabalhado antes com a empresa em projetos colaborativos de desenvolvimento de produtos,

- relacionados ao gerenciamento de riscos: em nenhum momento do projeto, os parceiros preocuparam-se em aplicar os instrumentos para visualizar, gerenciar e minimizar os riscos.

Este projeto apresentou os seguintes benefícios para a empresa estudada:

- ganhos no conhecimento em relação à parte agrícola;

- produto de sucesso;

- Inovação tecnológica.

Para o cliente foi a melhoria de produtividade.

As dificuldades enfrentadas para gerenciar este projeto foram:

- as pressões de prazo,

- o planejamento mais informal.

\subsection{Projeto colaborativo com o fornecedor}

O projeto de desenvolvimento de um novo produto com um de seus fornecedores foi o de uma colheitadeira para milho e outros cereais.

\subsubsection{Surgimento da parceria e motivação}

A parceria foi concretizada para incorporar a experiência do fornecedor em relação aos aspectos técnicos que envolviam o produto em questão. Para a empresa, tratava-se de um 
novo ramo de atuação, para o qual não possuía nenhum produto e, portanto, conhecimento e experiências necessários.

\subsubsection{Classificação do projeto e contribuição}

O projeto pode ser considerado como uma nova tecnologia para a empresa, mas não para o mercado, pois o conceito do produto já estava estabelecido. Havia, porém, um diferencial no produto, que era o nicho de mercado e sua versatilidade, pois além da colheita do milho, também poderia ser utilizado para a colheita da soja e do trigo.

A equipe base do projeto trabalhava em tempo integral e era formada por um gerente de projeto e um projetista - ambos pertencentes à empresa estudada - e uma equipe estendida formada por desenhistas e profissionais de apoio técnico que pertenciam ao fornecedor, empresa parceira. Os objetivos da colaboração foram respectivamente a pesquisa e o desenvolvimento, a assistência técnica durante o projeto, o treinamento, os ensaios e testes e a coleta de informações. A empresa estudada ficou responsável pela gestão e detalhamento técnico do projeto. Ao fornecedor - parceiro, coube a montagem dos protótipos e treinamento da equipe da empresa estudada sobre o funcionamento e tecnologias utilizadas por ele nos produtos.

Eram feitas reuniões de trabalho entre as equipes, a princípio na sede do fornecedor, passando para a empresa estudada posteriormente. Todos os assuntos tratados nessas reuniões eram registrados em um documento padrão da área de engenharia. A comunicação entre as equipes era por intermédio do telefone e do correio eletrônico. O critério para a escolha do parceiro foi a proximidade e o conhecimento pessoal dos donos a empresa estudada com o fornecedor-parceiro. O projeto teve a duração de dois anos (2004 e 2005). No início, o produto foi fabricado integralmente no fornecedor-parceiro, com a marca da empresa estudada. Hoje ele é produzido $90 \%$ na empresa estudada. 


\subsubsection{Avaliação dos fatores críticos}

Assim como no projeto anterior, o respondente discorreu sobre cada um dos fatores críticos conforme o roteiro de entrevistas presente no apêndice A. Os pareceres do respondente foram tabulados e os resultados estão agrupados em uma escala qualitativa de importância nos gráficos apresentados na seqüência.

Com relação aos FCS relacionados com a área de Gerenciamento de Projeto, o resultado é sumarizado no gráfico 12. Analisando o gráfico, é possível perceber que os FCS “objetivos definidos", "planos acordados", "monitoramento regular" e "comunicação entres os participantes" foram realizados plenamente. O respondente argumentou que os recursos humanos foram aquém do necessário. $\mathrm{O}$ escopo do projeto precisou ser redimensionado, pois no início estava muito amplo. As etapas parciais (milestones) não foram definidas no início do projeto.

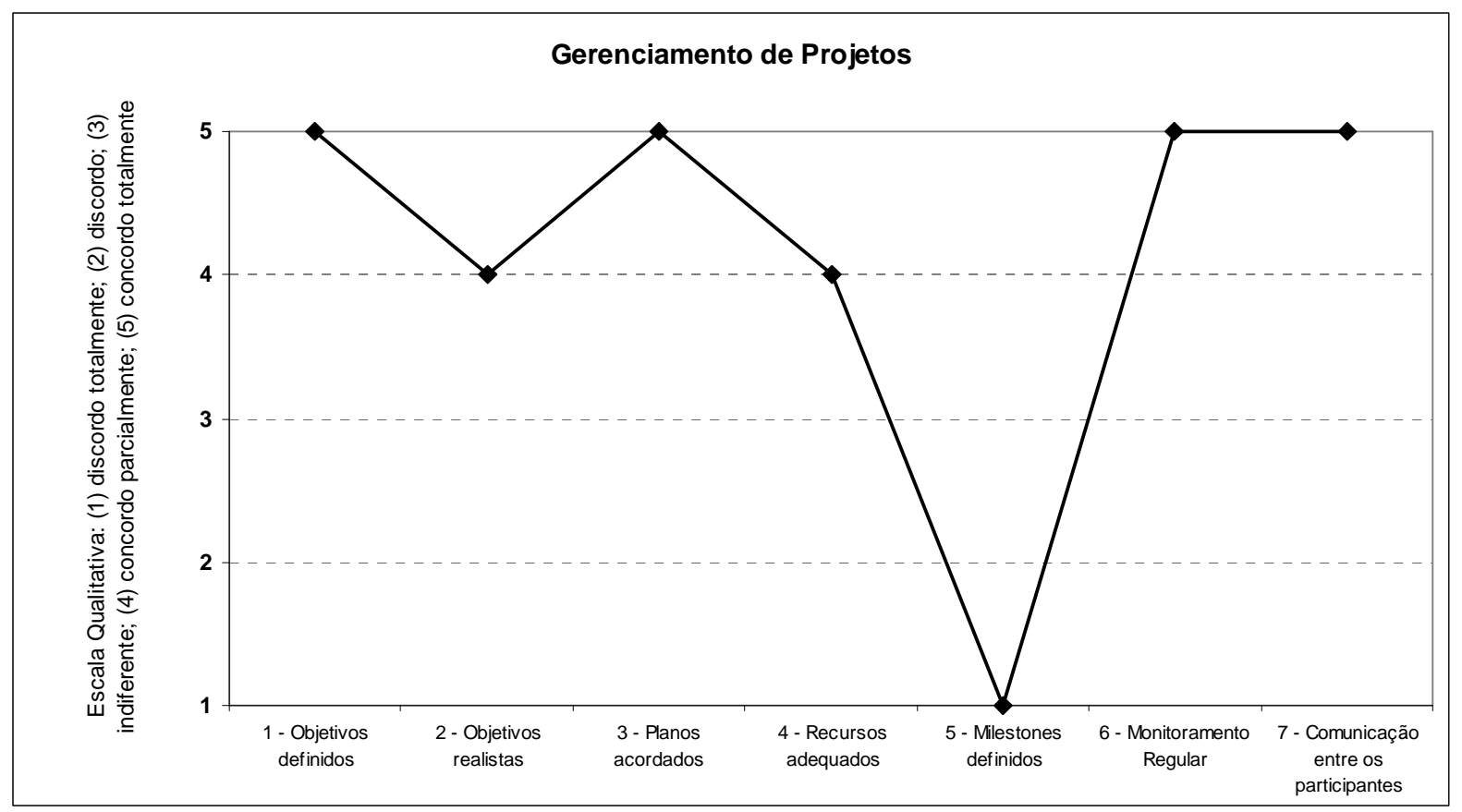

Gráfico 12. FCS da área Gerenciamento do Projeto no projeto com o fornecedor 
Em relação aos FCS da área Fatores Universais de Sucesso (gráfico 13), o respondente citou que nem todo o aprendizado obtido com o projeto foi documentado para pesquisas futuras, isto devido ao fato do número limitado de recursos humanos disponível para a tarefa. Os outros FCS (confiança, comprometimento, continuidade das equipes, relacionamento e o champion da colaboração) foram observados plenamente.

O gráfico 14 descreve os FCS relacionados ao Gerente do Projeto. O respondente comentou que o gerente desse projeto era inexperiente em relação ao gerenciamento do projeto, colaboração e conhecimentos técnicos, porém foi um bom negociador e possuía conhecimento das outras funções da empresa.

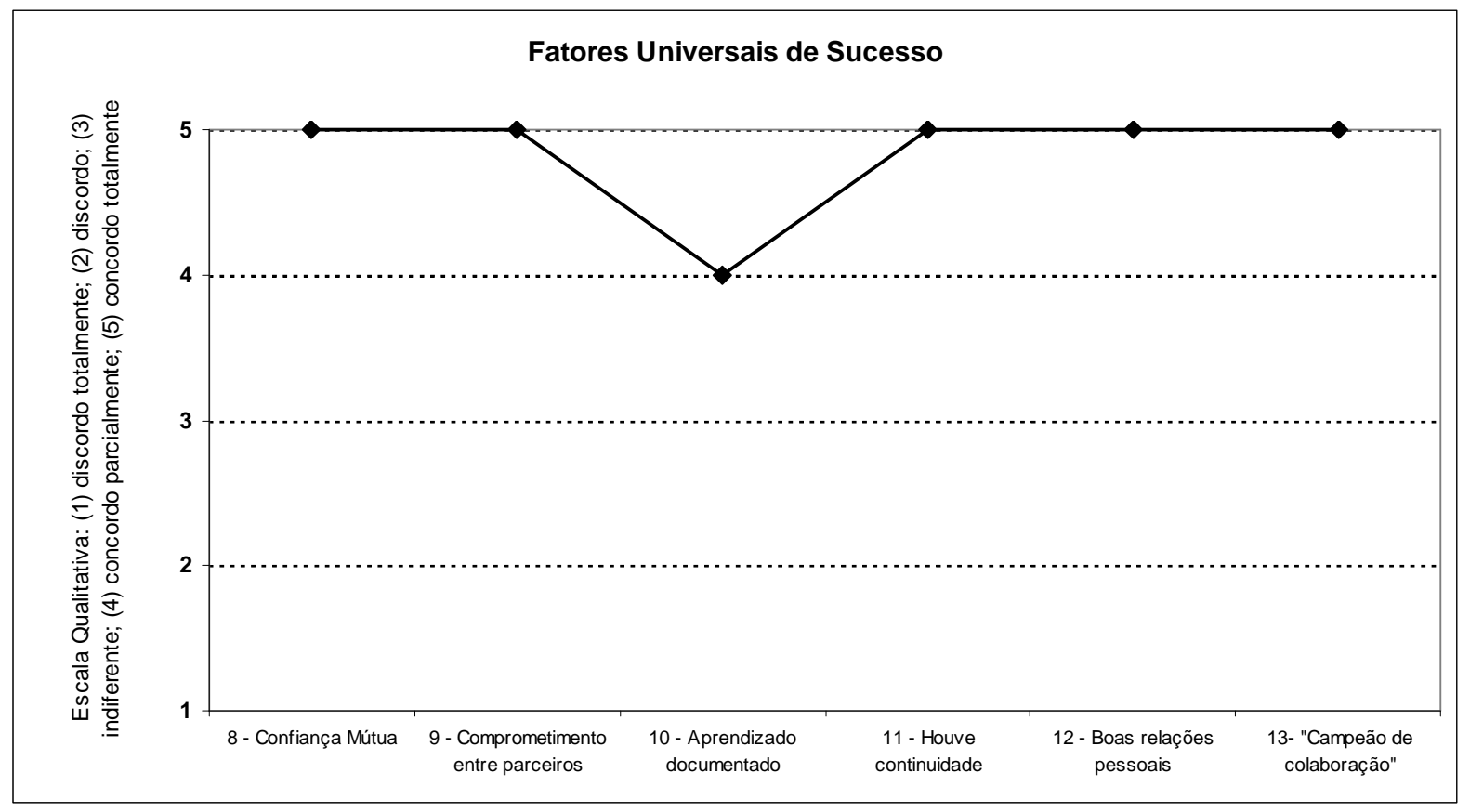

Gráfico 13. FCS da área Fatores Universais de Sucesso no projeto com o fornecedor 


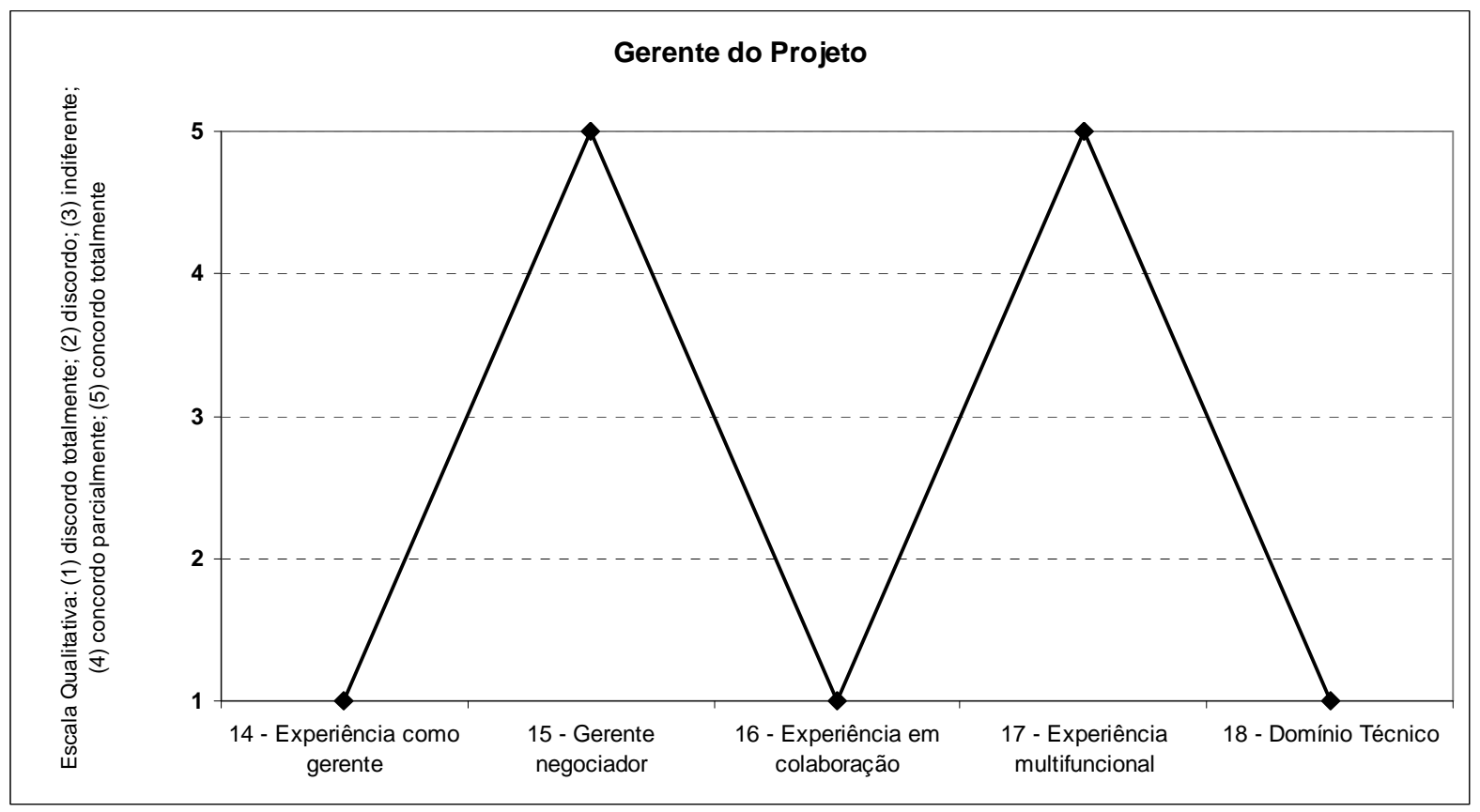

Gráfico 14. FCS da área Gerente do Projeto no projeto com o fornecedor

$\mathrm{Na}$ área Avaliação do Parceiro (gráfico 15), o respondente enfatizou que não houve a utilização de "agendas ocultas" por parte do fornecedor-parceiro. E foi o primeiro projeto em parceria com a empresa estudada. A experiência técnica dos profissionais do fornecedorparceiro na área de colheitas contribuiu para que a empresa estudada adquirisse novos conhecimentos na área. O fornecedor-parceiro respeitou os objetivos complementares da empresa estudada. Um outro problema identificado foi quanto às diferenças culturais. A empresa parceira apresentava algumas deficiências tais como: nível menor de maturidade em desenvolvimento de produto; não possuía a prática de trabalhar com desenhos detalhados de todo o produto; muitas informações técnicas eram registradas por meio de modelos físicos e protótipos armazenados na própria empresa; não possuía também prática e procedimentos de gestão de configuração de desenhos. Como resultado, membros da equipe do fornecedorparceiro, em determinadas situações durante o projeto, alteravam repentinamente os desenhos, 
ocasionando morosidade nas tarefas e um tempo maior para novas decisões, havendo desta forma um desrespeito cultural.

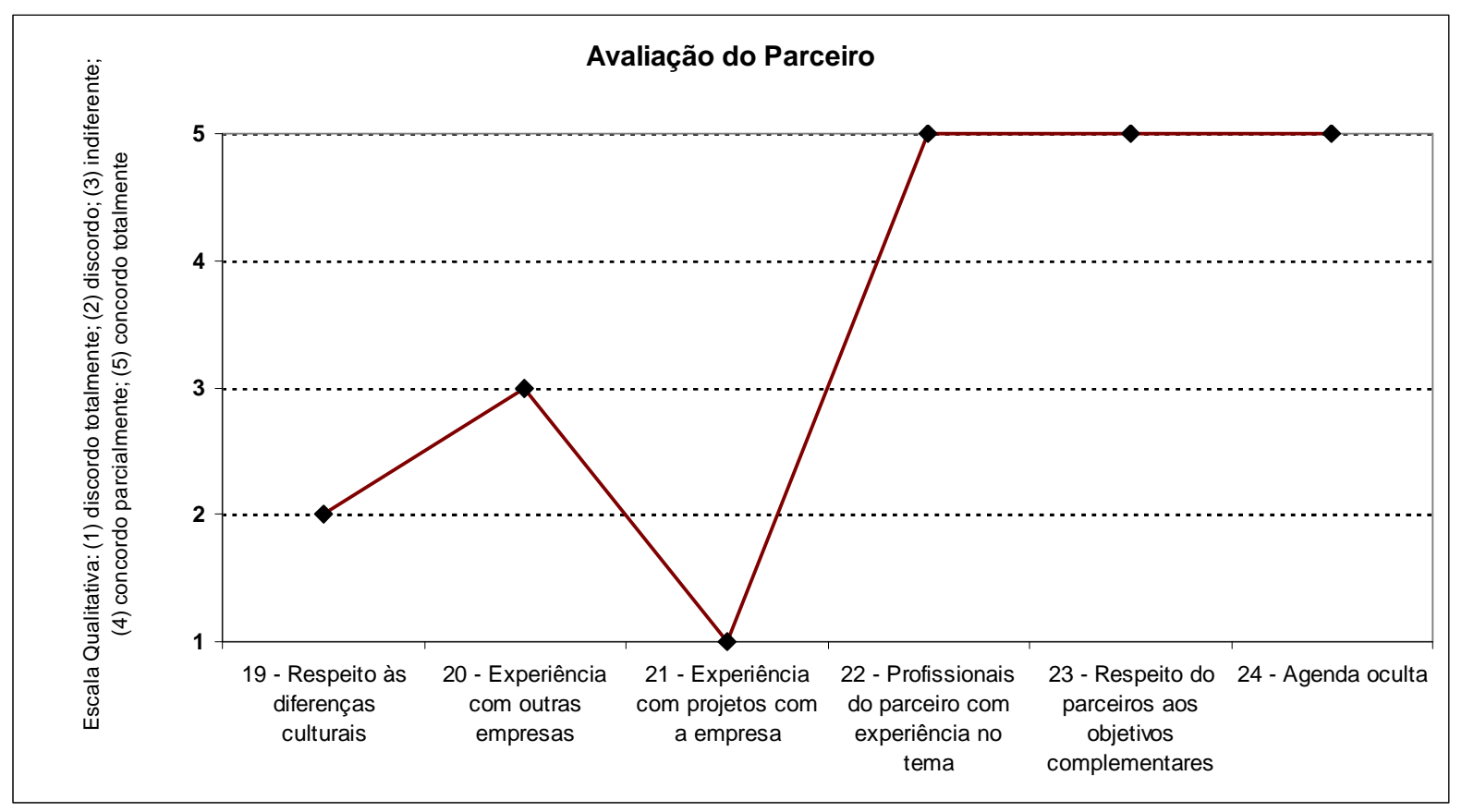

Gráfico 15. FCS da área Avaliação do Parceiro no projeto com o fornecedor

Para os FCS pertencentes às áreas Garantia de igualdade (gráfico 16), o respondente comentou que as duas partes foram beneficiadas pelo projeto, houve um equilíbrio de benefícios, na igualdade de poder e as duas partes puderam contribuir por igual.

Já para os FCS da área Influências do Ambiente (gráfico 17), o respondente afirmou que em relação ao fornecedor-parceiro, houve um aumento no faturamento e tornouse um canal de distribuição do produto. A empresa estudada lançou no mercado um produto que se transformou em sucesso comercial e tecnológico para ela, com aumento no faturamento de vendas nacionais e nas exportações, além de contribuir para a diminuição da sazonalidade. Trouxe também novos conhecimentos em termos de plantio e tecnologias. O respondente citou ainda que a empresa passava por um período de acertos na organização e reestruturação dos negócios em virtude da situação econômica vivida no setor agrícola. 


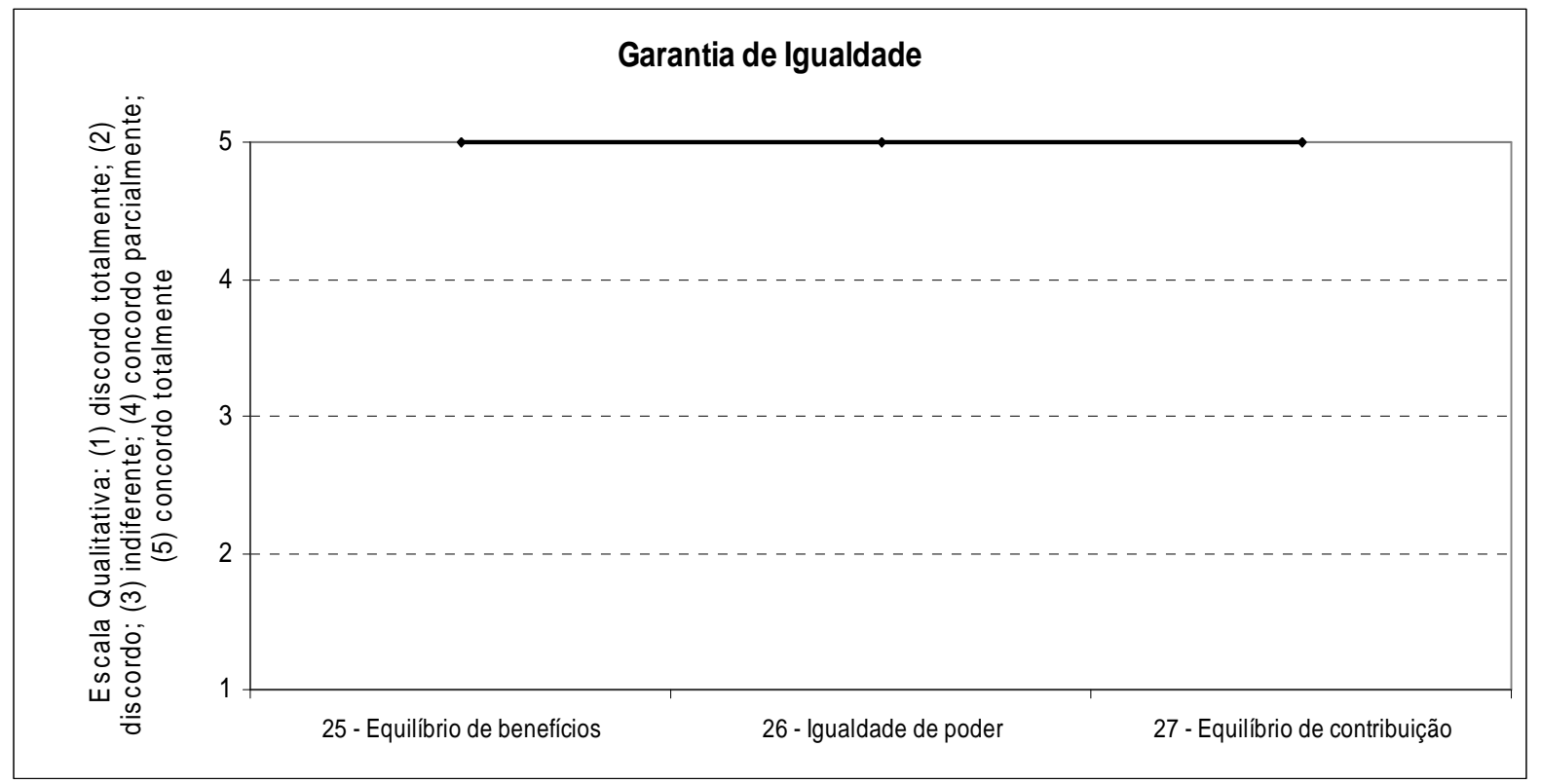

Gráfico 16. FCS da área Garantia de igualdade no projeto com o fornecedor

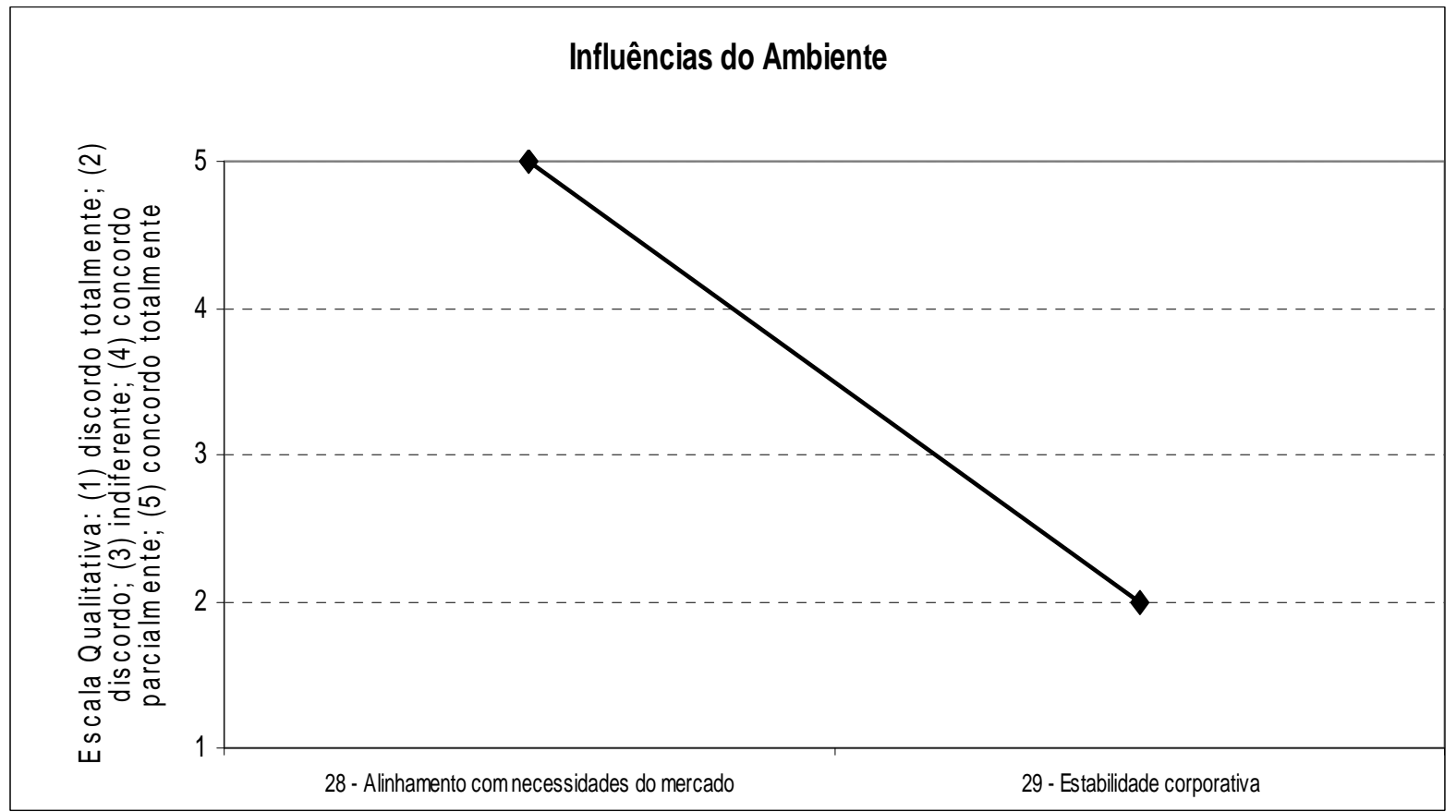

Gráfico 17. FCS da área Influência do ambiente no projeto com o fornecedor

Em relação à área de Gerenciamento de Riscos no Projeto, o respondente informou que em nenhum momento os parceiros fizeram uso de ferramentas que pudessem auxiliá-los 
na identificação, administração ou até na minimização de qualquer tipo de riscos que poderia surgir durante o ciclo de vida do projeto.

Como resultado final tem-se que os principais FCS observados por área foram:

- gerenciamento do projeto: os objetivos do projeto foram definidos claramente; os planos do projeto foram acordados mutuamente; houve monitoramento regular do progresso do projeto; a comunicação entre os participantes do projeto foi feita de forma eficaz;

- fatores universais de sucesso: houve confiança mútua e comprometimento entre os parceiros; houve continuidade das pessoas e bom relacionamento entre os parceiros; a direção da empresa estudada incentivou o projeto em todas as suas etapas.

- gerente do projeto: foi um bom negociador, possuía experiência multifuncional;

- avaliacão do parceiro: possuía experiência no tema do projeto; conhecia e respeitava os objetivos complementares além dos objetivos comuns; o fornecedor-parceiro não fazia uso de agendas ocultas;

- garantia de qualidade: neste projeto também houve equilíbrio de contribuição e benefícios além de igualdade de poder entre os parceiros;

- influências do ambiente: o produto veio ao encontro das necessidades do mercado; a empresa passou por período de reestruturação e acerto nos negócios em virtude da situação econômica vivida pelo setor.

Os FCS não realizados durante o projeto foram:

- relacionados ao gerenciamento do projeto: as etapas parciais não foram definidas no início do projeto; 
- relacionados ao gerente de projetos: não tinha experiência em gerenciamento de projetos e em colaboração; não tinha conhecimento técnico no tema do projeto;

- relacionados à avaliação do parceiro: o fornecedor não havia trabalhado anteriormente em projetos colaborativos com a empresa e sim apenas fornecia materiais;

- relacionados ao gerenciamento de riscos: em nenhum momento do ciclo de vida do projeto, os parceiros fizeram uso de procedimentos formais que pudessem auxiliar na identificação, administração ou minimização de riscos futuros.

Os benefícios advindos dessa colaboração para a empresa foram:

- produto com grande potencial e previsões de vendas em nível mundial;

- o produto contribuiu muito para diminuir a sazonalidade;

- agregação de conhecimentos em relação às inovações tecnológicas e ao plantio das culturas do milho, da soja e do trigo;

Para o fornecedor, os benefícios foram:

- o aumento no faturamento,

- tornou-se um canal de distribuição do produto.

A dificuldade encontrada pela empresa estudada nessa colaboração era em relação às alterações que o fornecedor-parceiro fazia nos desenhos e não informava ao projetista da empresa. Apesar de algumas divergências que foram solucionadas rapidamente, o resultado final do projeto permitiu uma satisfação mútua aos parceiros. 


\section{ANÁLISE}

O quadro 9 apresenta uma comparação dos FCS, sintetizados no referencial teórico, quanto à observação nos projetos colaborativos analisados.

Na coluna (2) foram listados os FCS que representam o total da lista do modelo teórico de Barnes, Parshby e Gibbons.

Na coluna (3) identificam-se os FCS presentes no projeto em colaboração com o cliente, por meio dos campos preenchidos em cinza.

$\mathrm{Na}$ coluna (4) estão os FCS presentes no relacionamento com o fornecedor, preenchidos na cor cinza.

Uma análise no quadro 9 permite demonstrar uma situação bastante similar entre os dois projetos estudados.

Mesmo assim, comenta-se separadamente cada um dos projetos, nas seções seguintes, antes de uma análise comparativa entre eles. 


\begin{tabular}{|c|c|c|c|}
\hline \multicolumn{4}{|c|}{ Fatores Críticos de Sucesso por área } \\
\hline \multirow{2}{*}{ Área (1) } & \multirow{2}{*}{ Síntese de Fatores Críticos (2) } & \multicolumn{2}{|c|}{$\begin{array}{c}\text { Projetos Colaborativos da } \\
\text { empresa estudada }\end{array}$} \\
\hline & & $\begin{array}{l}\text { com o cliente } \\
\text { (3) }\end{array}$ & $\begin{array}{c}\operatorname{com} 0 \\
\text { fornecedor (4) }\end{array}$ \\
\hline \multirow{7}{*}{ 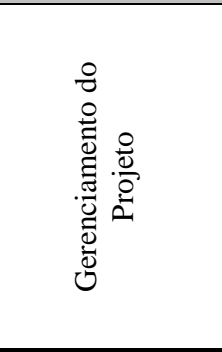 } & Objetivos e responsabilidades definidos & & \\
\hline & Objetivos realistas & & \\
\hline & Planos do projeto acordados mutuamente & & \\
\hline & Recursos adequados & & \\
\hline & Etapas parciais definidas (milestones) & & \\
\hline & Monitoramento & & \\
\hline & Comunicação eficiente & & \\
\hline \multirow{6}{*}{ 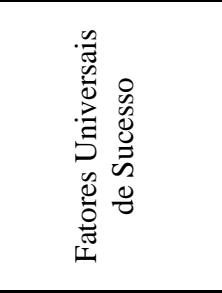 } & Confiança & & \\
\hline & Comprometimento & & \\
\hline & Aprendizado documentado & & \\
\hline & Continuidade das equipes & & \\
\hline & Bom relacionamento & & \\
\hline & Champion da Colaboração & & \\
\hline \multirow{5}{*}{ 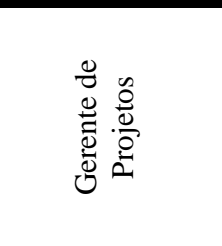 } & Experiência como gerente de projeto & & \\
\hline & Gerente negociador & & \\
\hline & Experiência em colaboração & & \\
\hline & Experiência multifuncional & & \\
\hline & Capacitação técnica & & \\
\hline \multirow{8}{*}{ 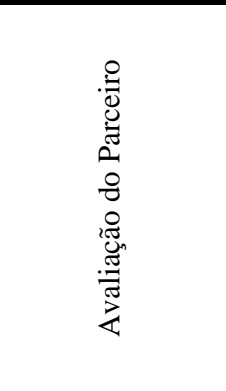 } & Respeito às diferenças culturais entre os parceiros & & \\
\hline & Experiência em colaboração com outras empresas & & \\
\hline & Experiências anteriores com projetos com a empresa & & \\
\hline & Profissionais do parceiro com experiência no tema & & \\
\hline & Respeito aos objetivos complementares & & \\
\hline & Sem agendas ocultas (objetivos não revelados) & & \\
\hline & Conhecimentos especializados & & \\
\hline & Habilidades complementares & & \\
\hline \multirow{3}{*}{ 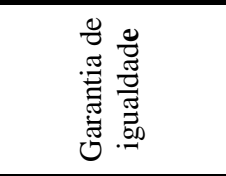 } & Equilíbrio de benefícios (Benefícios Mútuos) & & \\
\hline & Igualdade de poder & & \\
\hline & Equilíbrio de contribuição & & \\
\hline \multirow{2}{*}{ 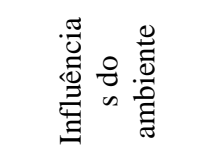 } & Alinhamento com as necessidades do mercado & & \\
\hline & Estabilidade corporativa & & \\
\hline $\begin{array}{l}\text { Gerenciamento } \\
\text { de Riscos }\end{array}$ & Análise e acompanhamento de riscos & & \\
\hline
\end{tabular}

Quadro 9. Comparação dos FCS do modelo teórico e os FCS dos projetos colaborativos (elaborado pelo autor) 


\subsection{Análise dos FCS observados no projeto colaborativo entre a empresa e cliente}

A tabela 4 apresenta uma análise percentual dos FCS observados no projeto colaborativo com o cliente, em relação aos FCS listados no modelo de Barnes.

\begin{tabular}{|l|c|c|c|}
\hline \multicolumn{1}{|c|}{ Áreas } & $\begin{array}{c}\text { FCS listados } \\
\text { no modelo de } \\
\text { Barnes por } \\
\text { área (1) }\end{array}$ & $\begin{array}{c}\text { FCS } \\
\text { observados no } \\
\text { projeto } \\
\text { colaborativo } \\
\text { por área (2) }\end{array}$ & $\begin{array}{c}\text { Percentual de } \\
\text { participação } \\
\text { por área } \\
\text { (2) / (1) }\end{array}$ \\
\hline Gerenciamento do Projeto & 7 & 5 & 71,4 \\
\hline Fatores Universais de Sucesso & 6 & 4 & 66,6 \\
\hline Gerente do Projeto & 5 & 4 & 80,0 \\
\hline Avaliação do Parceiro & 8 & 4 & 50,0 \\
\hline Garantia de Igualdade & 3 & 3 & 100,0 \\
\hline Influências do Ambiente & 2 & 2 & 100,0 \\
\hline Gerenciamento de Riscos & - & - & - \\
\hline TOTAL & $\mathbf{3 1}$ & $\mathbf{2 2}$ & $\mathbf{7 1 , 0}$ \\
\hline
\end{tabular}

Tabela 4. Percentual de participação por área - projeto colaborativo empresa e o cliente (elaborada pelo autor)

Trata-se de um projeto de sucesso e o primeiro aspecto é notar que grande parte dos fatores críticos identificados na literatura foram observados, ou 71,0\%. Isso reforça a teoria, indicando que os fatores da literatura são potencialmente importantes também no caso da IMA brasileira.

Nota-se inicialmente que na área Gerenciamento do Projeto, dos FCS listados no modelo teórico de Barnes (7), foram observados nesse projeto colaborativo (5) ou 71,4\%. Os FCS “objetivos realistas" e "etapas parciais definidas (milestones)" não foram observados, pois, a empresa fez reformulações nos objetivos realistas e não caracterizou as etapas parciais no início do projeto.

Em relação à área Fatores Universais de Sucesso foram observados 4 FCS dos 6 listados no modelo teórico, ou 66,6\%. Os FCS “aprendizado documentado" e a "presença de um champion" são importantes. O "aprendizado documentado" formaliza os eventos ocorridos durante o desenvolvimento do produto, permitindo a recuperação de informações em projetos futuros. A presença do champion contribui para o entusiasmo da equipe. 
Em relação à área Gerente do Projeto, o FCS “experiência em colaboração” não foi observado. Apesar de a literatura citar que a "experiência do gerente de projeto em colaboração" facilitaria a harmonização entre os diferentes objetivos e modos de operações dos parceiros, ela não fez falta no caso deste projeto em especial. Parece que este é um fator secundário e menor, sendo a experiência em gerenciamento de projetos, a capacitação técnica e de negociação fatores mais importantes e que por si só garantem o resultado, como no caso deste projeto.

Neste projeto, todos os FCS das áreas "Garantia de Igualdade" e "Influências do Ambiente" listados no modelo teórico de Barnes, foram observados, ou seja, 100\% . Inclusive, nos comentários e observações sobre o projeto ficou evidente que estes fatores foram fundamentais para obter-se o bom resultado do projeto. O bom relacionamento e compatibilidade cultural permitiram que os objetivos fossem alterados e negociados durante o projeto, garantindo a sua boa execução.

A área que apresentou a menor participação foi a Avaliação do Parceiro com $50 \%$. Nesta área, os FCS “conhecimentos especializados" e "habilidades complementares" que foram citados no modelo teórico, porém não explicados pelos autores (ver seção 4.4 a pagina 77) não foram observados para este projeto. Ao que parece eles não afetaram negativamente, dado que o projeto obteve bons resultados e o respondente identificou que não houve obstáculo de qualquer tipo em relação ao parceiro, tendo o projeto transcorrido sem qualquer problema. Isso indica também uma hipótese importante: a de que os fatores relacionados com as características do parceiro seriam a ausência de agenda oculta (objetivos não revelados), respeito aos objetivos complementares e a experiência no tema.

Fez-se também uma análise sobre o fator gerenciamento de risco do projeto, que não aparece no modelo de Barnes et al (2006) e na tabela 4, mas que foi identificado em outros 
estudos da literatura. O resultado é que, neste projeto, não foi realizada qualquer tipo de análise do tipo e isso não impediu o sucesso do mesmo. Deve-se notar, porém, que houve dificuldades e mudanças de objetivo durante o projeto e, portanto, a gestão de riscos poderia ter auxiliado a evitar este problema. O resultado faz supor a hipótese de que as presenças dos fatores universais possam, portanto, facilitar a solução dos problemas, minimizando a necessidade dos riscos. Deste modo, sugere-se uma investigação futura sobre o relacionamento entre fatores universais de sucesso e a gestão de riscos.

\subsection{Análise dos FCS observados no projeto colaborativo entre a empresa e o fornecedor}

A tabela 5 apresenta análise similar ao realizada na tabela 4, cujo objeto é o projeto em parceria com o fornecedor.

\begin{tabular}{|l|c|c|c|}
\hline \multicolumn{1}{|c|}{ Áreas } & $\begin{array}{c}\text { FCS listados } \\
\text { nodo modelo } \\
\text { de Barnes por } \\
\text { área (1) }\end{array}$ & $\begin{array}{c}\text { FCS } \\
\text { observados no } \\
\text { projeto } \\
\text { colaborativo } \\
\text { por área (2) }\end{array}$ & $\begin{array}{c}\text { Percentual de } \\
\text { participação }\end{array}$ \\
\hline Gerenciamento do Projeto & 7 & 4 & 57,1 \\
\hline Fatores Universais de Sucesso & 6 & 5 & 83,3 \\
\hline Gerente do Projeto & 5 & 2 & 40,0 \\
\hline Avaliação do Parceiro & 8 & 3 & 37,5 \\
\hline Garantia de Igualdade & 3 & 3 & 100,0 \\
\hline Influências do Ambiente & 2 & 1 & 50,0 \\
\hline Gerenciamento de Riscos & - & - & - \\
\hline TOTAL & $\mathbf{3 1}$ & $\mathbf{1 8}$ & $\mathbf{5 8 , 0}$ \\
\hline
\end{tabular}

Tabela 5. Percentual de participação por área - projeto colaborativo empresa e fornecedor (elaborada pelo autor)

$\mathrm{Na}$ área Gerenciamento do Projeto, foram observados quatro FCS dentre as listas de fatores possíveis ou 57,1 \%. Além dos FCS “objetivos realistas" e "etapas parciais definidas" que já foram citados na seção 7.1, o FCS "recurso adequado" não foi observado para este projeto. Este FCS também é importante, pois proporciona ganhos de tempo e custo, além de 
garantir uma qualidade superior para o projeto. Neste caso, apesar do projeto ter tido êxito, a ausência de recursos adequados ou um número limitado deles, afetou negativamente, reforçando a importância do FCS.

Segundo o respondente, a ausência do FCS "etapas parciais definidas", milestones definidos prejudicou o andamento inicial do projeto de tal forma que, no decorrer do projeto, eles foram definidos. Portanto, mesmo estando este FCS ausente e o projeto tenha sido um sucesso, esse caso reforça a importância desse fator como crítico para a colaboração.

$\mathrm{Na}$ área Fatores Universais de Sucesso, o FCS não observado foi o "aprendizado documentado", que já foi comentado na seção 7.1. Os demais foram observados, destacando aqui a presença do "champion da colaboração", papel exercido pela própria direção da empresa que se envolveu pessoalmente para facilitar e garantir todo apoio necessário para o projeto colaborativo.

A área Gerente do Projeto apresentou como pontos fortes, a sua capacidade de negociação e a experiência multifuncional, similar ao projeto com o cliente. O domínio técnico estava presente em membros do parceiro, sendo a experiência multifuncional do gerente do projeto fundamental para utilizar ("extrair") esta capacitação e torná-la efetiva na solução dos problemas do projeto. Os fatores experiência em colaboração e, neste caso experiência como gerente de projeto, mesmo ausentes não influenciaram negativamente, foram, portanto, neutras.

Poucos dos fatores ausentes nos dois projetos trouxeram prejuízos. Um dos casos em que ficou evidente é o FCS "etapas parciais definidas (milestones)" que trouxe prejuízos, principalmente ao projeto com o fornecedor.

A área Avaliação do Parceiro apresentou menor percentual, 37,5\%, resultado novamente similar ao do projeto com o Cliente. Apenas três FCS foram observados e os 
demais não foram sentidos como prejudiciais ao projeto. A análise é similar ao do projeto com o cliente, demonstrando que experiências anteriores do parceiro não seriam tão prejudiciais.

Destaque deve ser feito para o FCS "respeito às diferenças culturais entre os parceiros". Ele não foi realizado, e, segundo o depoimento do respondente, a sua ausência trouxe obstáculos e prejuízos ao andamento do projeto. Em especial, devido aos procedimentos e cuidados com o gerenciamento das configurações dos desenhos dos projetos. Portanto, mesmo estando ausente, o resultado reforçou a importância deste fator crítico.

As áreas "Garantia de Igualdade" e "Influências do Ambiente" apresentaram na média, um percentual de $75 \%$ de FCS e, tal qual o projeto anterior, foram ás áreas com maior adequação ao proposto pela literatura. Não foi observada aqui a "estabilidade corporativa", isto é, a ausência de mudanças na organização, a reestruturação de equipes de projeto durante o projeto. No decorrer deste projeto houve mudanças no ambiente interno e externo dos negócios que afetaram o desenvolvimento da parceria.

\subsection{Análise comparativa dos projetos}

O primeiro fato que chama a atenção é a grande similaridade entre os FCS presentes nos dois projetos. Analisando o quadro 9, demonstra-se que poucas são as divergências entre os dois projetos. Porém quando ocorreram houve prejuízos aos projetos. É o caso de "recursos adequados", "respeito às diferenças culturais" e "estabilidade corporativa", faltantes da coluna 4, projeto com fornecedor, e que trouxeram prejuízos na forma de barreiras a este projeto, solucionadas durante o projeto. No caso do projeto com o cliente, coluna 3 do quadro 9 , há a ausência do "champion de colaboração". 
Os fatores das áreas: "Garantia de Igualdade", "Influências do Ambiente" e "Universais de Sucesso" foram os mais presentes em ambos os projetos e demonstraram ser realmente fundamentais para o sucesso da colaboração. Eles foram responsáveis por auxiliar a suplantar os obstáculos gerados por outros FCS.

Outro aspecto que chama a atenção é com relação à avaliação dos parceiros. Nos dois projetos, a ausência de experiência dos parceiros com colaborações em outras empresas ou com a própria empresa não influenciaram a empresa estudada. Nos dois também foi fundamental o FCS "respeito aos objetivos complementares". Esse parece ser o FCS realmente crítico. Sugerindo que os demais possam possam ser secundários e, portanto, menos importantes.

O FCS adicionado "gerenciamento de riscos" não foi verificado em nenhum projeto e foi considerado como um fator não crítico na percepção do gerente de projeto. Porém, se considerarmos os problemas que surgiram com a falta de recursos e alterações nos requisitos no projeto com o fornecedor, fica aqui a dúvida se realmente a presença destes fatores não poderia ter evitado esses problemas. Uma hipótese que o trabalho sugere é a de que o efeito da gestão de riscos teria sido minimizado pela presença forte dos fatores universais como confiança e bom relacionamento.

As áreas "Gerenciamento do Projeto" e "Gerente do Projeto" também apresentaram uma expressiva média percentual na comparação entre os FCS observados e os FCS do modelo teórico apresentado com 64,2\% e 60,0\% respectivamente (tabela 6). As áreas "Gerente do Projeto", "Garantia de Igualdade" e "Influências do Ambiente", no projeto colaborativo entre a empresa e o cliente, apresentaram um percentual de comparação entre os FCS observados e os FCS presentes no modelo teórico de 80,0\% e 100,0\% respectivamente. 
A área "Avaliação do Parceiro" apresentou o resultado comparativo mais fraco entres as demais, tanto por projeto $(50,0 \%$ e $37,5 \%)$ como na média entre os dois projetos $(43,7 \%)$.

\begin{tabular}{|l|c|c|c|}
\hline \multicolumn{1}{|c|}{ Áreas } & $\begin{array}{c}\text { Projeto } \\
\text { empresa e } \\
\text { cliente (\%) } \\
(\mathbf{1})\end{array}$ & $\begin{array}{c}\text { Projeto } \\
\text { empresa e } \\
\text { fornecedor (\%) } \\
(\mathbf{2})\end{array}$ & $\begin{array}{c}\text { Média } \\
\text { Percentual (\%) } \\
(\mathbf{1 + 2}) / \mathbf{2} \\
\mathbf{( 3 )}\end{array}$ \\
\hline Gerenciamento do Projeto & 71,4 & 57,1 & 64,2 \\
\hline Fatores Universais de Sucesso & 66,6 & 83,3 & 74,9 \\
\hline Gerente do Projeto & 80,0 & 40,0 & 60,0 \\
\hline Avaliação do Parceiro & 50,0 & 37,5 & 43,7 \\
\hline Garantia de Igualdade & 100,0 & 100,0 & 100,0 \\
\hline Influências do Ambiente & 100,0 & 50,0 & 75,0 \\
\hline Gerenciamento de Riscos & - & - & - \\
\hline TOTAL & $\mathbf{7 1 , 0}$ & $\mathbf{5 8 , 0}$ & $\mathbf{6 4 , 5}$ \\
\hline
\end{tabular}

Tabela 6. Variação percentual por área entre os dois projetos colaborativos (elaborado pelo autor)

A finalização desta análise comparativa é complementada com o gráfico 18. Nele pode ser observado, por intermédio das linhas contínuas e das linhas tracejadas, a similaridade entre os FCS existentes nos dois projetos colaborativos realizados pela empresa estudada. 


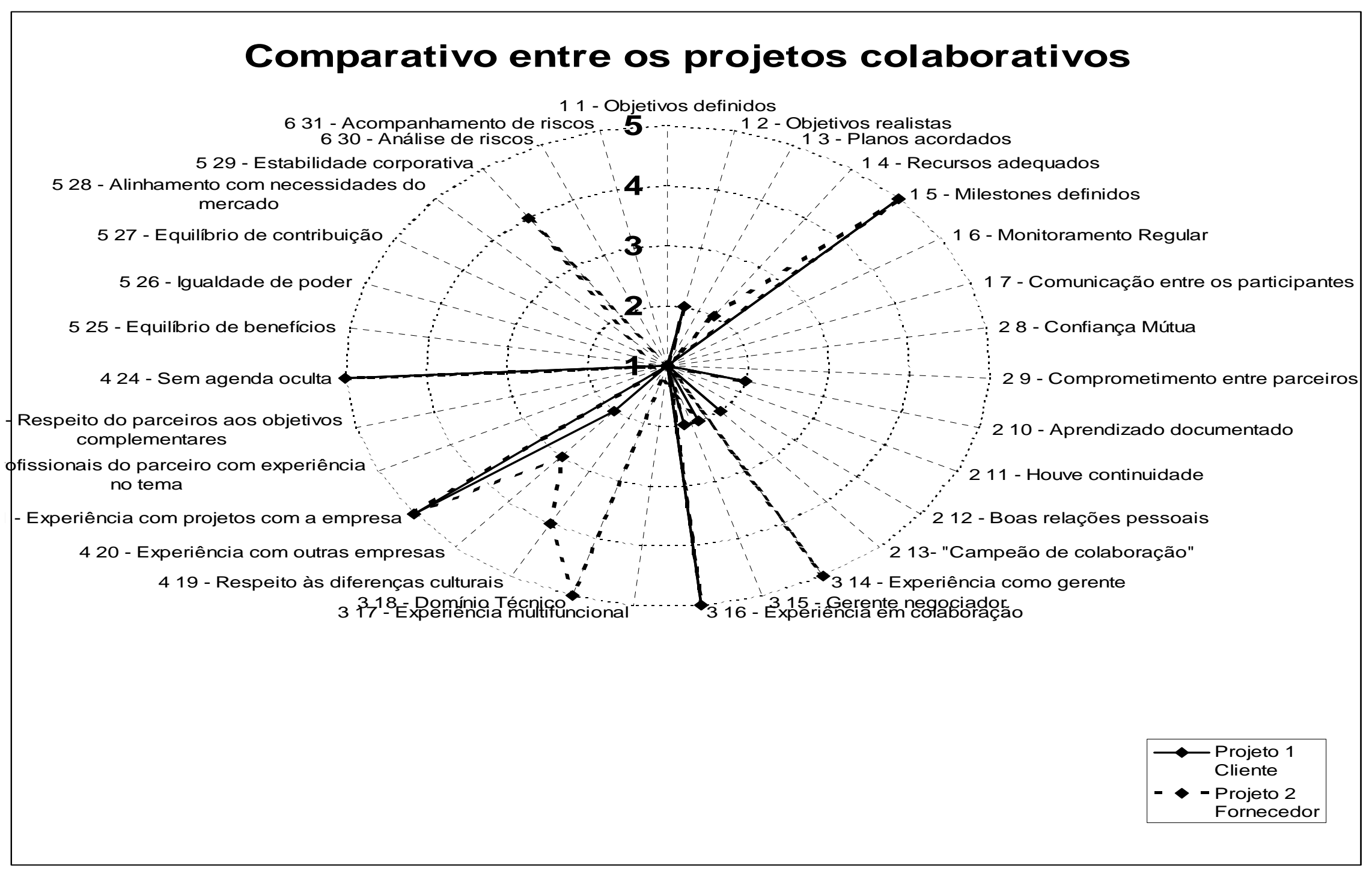

Gráfico 18. Comparação entre os projetos colaborativos

(elaborado pelo autor) 


\section{CONSIDERAÇÕES FINAIS E CONCLUSÕES}

O trabalho apresenta uma revisão da literatura sobre os fatores críticos para projetos de desenvolvimento de produtos que envolvem colaboração. Os modelos encontrados foram estruturados tendo como referências as revisões bibliográficas, estudos de caso e surveys em indústrias diversas. Além da quantidade de fatores, chamou a atenção o reconhecimento dos próprios autores desses trabalhos da necessidade de validar, isto é, testar estes modelos, ou listas, de fatores críticos em outras condições.

A análise teórica identificou também a possibilidade de um fator crítico adicional, a gestão de riscos do projeto. A partir de então, elaborou-se uma pesquisa de campo com o intuito de verificar estes fatores críticos, no caso a IMA brasileira. Optou-se por estudar uma única empresa, com nível avançado de maturidade em PDP, frente aos padrões do segmento que, conforme identificado na revisão bibliográfica não é elevado frente a outras indústrias como a automobilística.

O trabalho apresentou os resultados da avaliação de fatores críticos para o sucesso de dois projetos colaborativos que envolveram significativa inovação. Comparou-se dois projetos de sucesso, um deles desenvolvido em parceria com o cliente e outro em parceria com um fornecedor. Os FCS presentes nos dois projetos foram comparados com a literatura e entre si.

A primeira conclusão importante da pesquisa é que os fatores propostos na literatura foram em grande parte reforçados por esta pesquisa. A tabela 6 mostra que $64,5 \%$ deles foram verificados, em média, nos dois projetos, sendo que a grande parte foi considerada pelos gerentes de projetos da empresa como fundamentais para o sucesso dos projetos. Isso significa que tais listas podem sim ser úteis em levantamentos de campo neste setor.

A segunda conclusão é que o trabalho aponta oportunidades para a simplificação da lista de FCS identificada. O aspecto em que isso está mais evidente é quanto aos fatores da 
categoria "Avaliação do Parceiro". Muitos dos fatores ditos críticos nesta categoria, tais como experiências prévias de colaboração do parceiro, estavam ausentes e não foram consideradas geradoras de obstáculos ao andamento do projeto. Isso implica que talvez não sejam fatores “críticos” e, portanto, poderiam ser simplificados em levantamentos na área.

Uma terceira conclusão da pesquisa emerge da similaridade entre os FCS observados nos dois projetos. A opção pela estratificação quanto ao tipo de colaboração foi motivada pela hipótese de que poderia haver diferenças relacionadas a esse aspecto, sugeridas na literatura. Os dados comparativos destes dois projetos, porém, indicam para que não haja diferenças significativas quanto ao tipo de parceiro. Mostra sim que os fatores universais de sucesso foram fundamentais, reforçando a teoria da área.

Essa conclusão, logicamente, precisa ser tomada com cuidado. O resultado é pouco expressivo, pois, a amostra de projetos é pequena. Esta, inclusive, é uma questão a ser melhor entendida. $\mathrm{Na}$ busca de casos a fazerem parte da pesquisa, a identificação de projetos inovadores e ao mesmo tempo colaborativos, mostrou-se uma tarefa muito difícil.

Outra conclusão do estudo é a identificação da hipótese de existência de fatores críticos que podem estar sendo erroneamente citados na literatura. Um exemplo é o fator “conhecimento técnico" do Gerente de Projeto. Nos dois projetos, a maior competência técnica estava presente na equipe, porém, não na figura do Gerente de Projeto. Elas eram de domínio de profissionais dos parceiros que participavam da equipe. Porém, isso não significou empecilho ou obstáculo para a condução do projeto. As competências do gerente de projeto em negociação e em visão multifuncional foram suficientes para criar uma visão comum, no caso, um bom foco no mercado e objetivos do projeto.

Assim, o trabalho indica uma hipótese de que os fatores críticos "domínio técnico do gerente de projeto" (18 da área Gerente de Projeto) e "profissionais do parceiro com experiência no tema" (22 da área Avaliação do Parceiro) poderiam ser sintetizados em um 
único, sobre a equipe de projeto, denominado "Equipe com todas as competências técnicas necessárias". Isso porque, conforme demonstrado nos casos, mais importante é que exista a competência na equipe de projeto, independentemente se ela está no gerente de projeto ou no parceiro. Outros fatores como confiança, perfil de negociação do gerente e experiência multifuncional do gerente permitiriam que esse conhecimento da equipe fosse efetivamente transformado em boas soluções técnicas, garantindo o sucesso do projeto.

Este trabalho é um primeiro esforço para a identificação e elaboração de uma lista de FCS que pode ser validada para a IMA nacional. A principal contribuição é demonstrar uma sistematização da literatura da área, identificando fatores críticos presentes na literatura. Outra contribuição é uma primeira verificação desses fatores em casos da indústria de máquinas agrícolas nacional, identificando aspectos que podem orientar outros pesquisadores na utilização destes fatores em estudos mais amplos, do tipo levantamento, específicos sobre essa indústria.

O trabalho serve também como um alerta sobre a importância do tema. Desenvolver técnicas, métodos e modelos gerenciais para a IMA é fundamental para a competitividade do país. Um dos aspectos é a colaboração. A principal sugestão para trabalhos futuros é a realização do levantamento sobre a situação da colaboração e dos fatores críticos de sucesso neste tipo de projeto e indústria. 


\section{REFERÊNCIAS BIBLIOGRÁFICAS}

ABIMAQ. Informaq Jornal. Máquinas agrícolas contribuem para resultado positivo. n.102, maio, 2007. Disponível em <http://www.abimaq.com.br>. Acesso em: 28 de junho de 2007.

ALBENY, R. M. Análise da importância da mensuração e controle do valor da exposição a riscos em projetos de desenvolvimento de produtos complexos. $114 \mathrm{f}$ - Dissertação (Mestrado) - Escola Politécnica da Universidade de São Paulo, 2007.

ANFAVEA. A Indústria Automobilística Brasileira - 50 Anos. São Paulo: 2006a. Disponível em <http://www.anfavea.com.br/50 anos.html.> Acesso em: 26 de junho de 2007.

Anuário Estatístico da Indústria Automobilística Brasileira. São Paulo: 2006b. Disponível em <http://www.anfavea.com.br/anuário2007/cap01.2007pdf.>. Acesso em: 16 de junho de 2007.

ARAÚJO, C. Softwares de apoio ao gerenciamento ágil de projetos colaborativos de novos produtos: análise teórica e identificação de requisitos. $150 \mathrm{f}$. Dissertação (Mestrado) - Escola de Engenharia de São Carlos da Universidade de São Paulo, 2008.

AVELLAR, A. P. Relatório Setorial Final. setor: Bens de Capital, 2008. Disponível em < http://www.finep.gov.br/PortalDPP/relatorio_setorial_final/relatorio_setorial_final_impressao .asp?1st_setor=5, 2008>. Acesso em: 21 de março de 2008.

BADIN, N. T. Modelo de referência para o processo de desenvolvimento de produtos integrando fornecedores e baseado nos conceitos de engenharia simultânea, custeio-alvo e empresa virtual. 223 f. Tese (Doutorado) - Universidade Federal de Santa Catarina, 2005.

BARCZAK, G; WILWEMON, D. Factors influencing product development teams satisfaction. European Journal of Innovation Management, vol. 4, n. 1, p. 32 $\pm 36,2001$.

BARNES, T. A; PASHBY, I. R.; GIBBONS, A. M. Managing collaborative R\&D projects development of a practical management tool. International Journal of Project Management, 24, 395-404, 2006.

Effective University - Industry Interaction: A multi-case evaluation of collaborative R\&D projects. European Management Journal, vol. 20, no.3, pp. 272-285, 2002.

BEJARANO V.C. et al. Equipes Virtuais: um estudo de caso na indústria têxtil norteamericana. Revista Produção, SP, vol.16, n.1, p.161-170, jan./abr, 2006.

BELZER, K. The Program Office: A business results enabler, 2000. Disponível em <http://www.pmforum.org/library/papers/2001/ProgramOfficeFinal.pdf >. Acesso em: $01 \mathrm{de}$ julho de 2007.

BERTO, R. M. V. S.;NAKANO, D. N. A. A produção científica nos Anais do Encontro Nacional de Engenharia de Produção: um levantamento de métodos e tipos de pesquisa. In: Encontro Nacional de Engenharia de Produção 1999. Disponível em 
<http://www.abepro.org.br/biblioteca/ENEGEP1999_A0943.pdf >. Acesso em: 04 de março de 2008.

BSTIELER, L. Trust formation in collaborative new product development. Journal of Product Innovation Management, vol.23, p. 56-72, 2006.

CALABRESE, G. - Communication and cooperation in product development: a case study of a European car producer. R \& D Management 27, 3, 1997.

CAPELLI, N. - Agricultura Brasileira e o Fenômeno da Globalização, 2008. Disponível em <http:// gpsglobal.com.br>. Acesso em: 19 de março de 2008.

CERRI, D. G. P. Agricultura de precisão em cana de açúcar: instrumentação de uma colhedora, mapeamento da produtividade e de atributos do solo. $156 \mathrm{f}$. Doutorado (Tese) - Universidade Estadual de Campinas, 2005.

CHEN, H. C; LING, F.S.; CHEN, W. Project scheduling for collaborative product development using DSM. International Journal of Project Management 21; 291-299, 2003.

CHEN, P.; PARTINGTON, D. - Three conceptual levels of construction project management work. International Journal of Project Management. 24, 412-421, 2006.

CHESBROUGH, H. W. Open Innovation: The New Imperative for Creating and Profiting from Technology. Boston: Harvard Business School Press, 2003.

2003

The era of open innovation. Mit Sloan Management Review. v. 44, n. 3, spring,

; SCHWARTS, K. Innovating business models with co-development partnerships. Research Technology Management, v. 50, n. 1, jan./feb. 2007.

CHURCHILL JR. GILBERT A.; PETER, J. PAUL. Marketing: criando valor para os clientes. São Paulo: Saraiva, 2000.

CLARK, K. B.; FUJIMOTO, T. Product development performance: strategy, organization and management in the world auto industry. Boston: Harvard Business School Press, 1991.

; WHEELRIGHT, S.C. Managing new product and process development: text and cases. New York: The Free Press, 1993.

CLARK, R. L.; MCGUCKIN, R. L. Variable rate application equipment for precision farming, $\quad 1996 . \quad$ Disponível em $<$ http://www.engr.uga.edu/research/groups/precisionfarming/clarck_urt.html\#over>. Acesso em: 22 de junho de 2007. 
CLARO, D. P; OLIVEIRA CLARO, P. B. Gerenciando relacionamentos colaborativos com fornecedores. RAE-Revista de Administração de Empresas. São Paulo, vol. 44, n. 4, p. 69 , out./dez. 2004.

COOPER, L.P. A research agenda to reduce risk in new product development through knowledge management a practitioner perspective. Journal Engeneering Technology Management. 20, pg. 117-140, 2003.

CORRÊA, F.C. Propostas de melhoria para o PDP de uma empresa de máquinas agrícolas com base no modelo de PDP da Toyota, 201 f. Dissertação (Mestrado) Universidade Federal de São Carlos, 2007.

DALL'AGNOL, R. Desenvolvimento de novos produtos através do gerenciamento simultâneo de projetos (GSP): um estudo de caso no setor de máquinas agrícolas, 86f. Dissertação (Mestrado) - Universidade Federal do Rio Grande do Sul, 2001.

DAS, T.K. E TENG, B.S. A Resource based theory of strategic alliances. Journal of Management. 26(1): 31-61, 2000.

DODGSON, M. The future for technological collaboration. Futures, p. 459-470, junho, 1992.

DOMAZET et al. An Infrastructure for Inter-Organizational Collaborative Product Development. Proceedings of the 33rd Hawaii International Conference on System Sciences, 2000 .

DONG, T. et al. A collaborative approach to assembly sequence planning. Advanced Engineering Informatics 19, 155-168, 2005.

EMDEN, CALANTONE e DROGE. Collaborating for New Product Development: Selecting the Partner with Maximum Potential to Create Value. Journal of Product Innovation Management 23:330-341, 2006.

ENGWALL et al. Models in Action: How management models are interpreted in new product development. R\&D Management, v. 35, n. 4, p. 427-439, 2005.

EVARISTO, R.; FENEMA, P.C. A typology of project management: emergence and evolution of news forms. International Journal of Project Management, v. 17, n.5, p. 275$281,1999$.

FINHOLT, T. A. Collaboratories. Annual review of information science and technology, 36, 73-107, 2002.

GADANHA Jr., C. D. Máquinas e implementos agrícolas no Brasil. São Paulo: IPT, p. 469, 1991.

GIL, A.C. Como elaborar projetos e pesquisa. São Paulo: Atlas, 1995.

GRIFFIN, A. The effect of project and process characteristics on product development cycle time. Journal of Marketing Research, v. 34, no. 1, p. 24-35, 1997. 
GRUDIN, J. Computer-supported cooperative work: its history and participation. IEEE Computer, v.27, n. 5, p. 19-26, 1994.

HAGEDOORN, J. Understanding the rationale of strategic technology partnering: interorganizational modes of co-operation and sectorial differences. Strategic Management Journal, n. 14, p. 371-386, 1993.

HAMEL, G.; DOZ, Y.; PRAHALAD, C.K. Collaborative with your competitors and win. Harvard Business Review, v. 67, n.1, pp.133-139, 1989.

HEINZ, U. et al. Leadership and cooperation as success factors in innovative R\&D projects on electronics platforms. Team Performance Management, v. 12, n. 3/4, p. 66-76, 2006.

HELDMAN, K. Gerência de Projetos: guia para exame oficial do PMI; tradução de Teresa Félix - Rio de Janeiro: Campus, 2003.

HERTEL, G. et al. Managing virtual teams: a review of current empirical research. Human Resource Management Review, v. 15, p. 69-95, 2005.

HOLMSTRÖN, J. et al. Implementing collaboration process networks. The International Journal of Logistics Management, v. 13, n.2, p. 39-50, 2002.

HUNOFF, R. Máquinas agrícolas - curva para cima de novo. Revista Autodata. São Paulo, n. 218, p. 60, out, 2007.

HUSTON, L.; SAKKAB, N. Connect and Develop: inside Procter \& Gamble's new model for innovation. Harvard Business Review, march, 2006.

HYVÄRI, I. Success of projects in different organizational conditions. Project Management Journal, setembro, p.33-41, 2006.

IBGE. Pesquisa de Inovação Tecnológica, 2005. Disponível em: <http://www.ibge.gov.br/home/estatistica/economia/industria/pintec/2003/pintec2003.pdf>. Acesso em: 11 de julho de 2008.

Pesquisa de Inovação Tecnológica, 2007(a). Disponível em: <http://www.ibge.gov.br/home/estatistica/economia/industria/pintec/2005/default.shtm>. Acesso em: 18 de fevereiro de 2008.

- Cadastro Nacional de Atividades Econômicas, 2007(b). Disponível em:<http:/www.ibge.gov.br/concla>. Acesso em: 15 de outubro de 2007.

Levantamentos Sistemáticos da Produção Agrícola, abril, 2008. Disponível em: <http://www.ibge.gov.br/home/estatística/indicadores/agropecuaria/lspa_200804_5.shtm〉. Acesso em: 07 de Maio de 2008.

JUCÁ Jr., A.S. Gestão de projetos em empresas de base tecnológicas na área de software: análise do nível de maturidade e aplicabilidade de escritórios de projetos. 124f. Dissertação (Mestrado) - Escola de Engenharia de São Carlos, Universidade de São Paulo, São Carlos, 2005. 
KADEFORS, A. Trust in Project relationships - inside the black Box. International Journal of Project Management, 22, p. 175-182, 2004.

KAYIS, B. IRMAS - development of a risk management tool for collaborative multi-site, multi-partner new product development projects. Journal of Manufacturing Techonology Management, vol. 18, n. 4, p. 387-414, 2007.

KERZNER, H. Project Management: a systems approach to planning, scheduling and controlling - 6. ed. Van Nostrand Reinhold Co., New York, 1998.

KLEINSMANN, M.; VALKENBURG, R. Learning from collaborative new product development projects. Journal of Workplace Learning, v. 17, n. 3, p. 146-156, 2005.

KNUDSEN, M.P. The relative importance of interfirm relationships and knowledge transfer for new product development success. Journal Product Innovation Management, v. 24, p. 117-138, 2007.

KOLLTVEIT, et al. Perspectives on project management. International Journal of Project Management, v. 25, p. 3-9, 2007.

KRISHNAN, V.; ULRICH, K. T. Product Development Decisions: a Review of the Literature. Management Science, v. 47, n.1, p.1-21, 2001.

LAM, P.K.; CHIN, K.S. Project factors influencing conflict intensity and handling styles in collaborative NPD. Creativity and Innovation Management, v. 13, n. 1, march, 2004.

; PUN, K.F. Managing conflict in collaborative new product development: a supplier perspective. International Journal of Quality \& Realibility Management, v. 24, n. 9, p. 891-907, 2007.

LASZLO, G.P. Project management: a quality management approach. The TQM Magazine, v.11, n.3, p. 157-160, 1999.

LAZZARINI, S. Estudos de caso: aplicações e limitações do método para fins de pesquisa. Economia \& Empresa, São Paulo, v. 2, p. 17-26, out./dez. 1995.

LIPNACK, J. E STAMPS, J. Virtual Teams. New York: John Wiley, 1997.

LLORI, M.O.; OKE, J.S.; SANNI, S.A. Management of new product development in selected food companies in Nigeria. Technovation, v. 20, p. 333-342, 2000.

MACCARTHY, I.P. et al. New product development as a complex adaptive systems of decisions. Journal of Product and Innovation Management, v. 23, p. 437-456, 2006.

MANO, A. P. Gestão de desenvolvimento de produtos na indústria de máquinas e implementos agrícolas: estudo de casos em empresas nacionais de grande porte. $126 \mathrm{f}$. Dissertação (Mestrado) - Universidade Federal de São Carlos, 2006.

MARTINEZ, J. Precisão via satélite: Editorial. Revista O Sulco (edição brasileira da revista agrícola mundial publicada em 12 línguas pela Deere \& Company e suas subsidiárias), ano 112, n.. 27, p. 3, outono, 2007. 
MARTINI et al. Tecnologia Aplicada. Revista Cultivar Máquinas. Pelotas, RS. ano IV, n. 49, p. 22-26, ISSN 1676-0158, fev, 2006.

MARTINS, G. A. Estudo de Caso: uma estratégia de pesquisa. São Paulo: Atlas, 2006.

MEGLIORINI, E. Análise crítica dos conceitos de mensuração utilizados por empresas brasileiras produtoras de bens de capital sob encomenda., $214 \mathrm{f}$. Tese (Doutorado) Faculdade de Economia e Administração, Universidade de São Paulo, São Paulo, 2003.

MIALHE, L. G.. Manual de mecanização agrícola. São Paulo: Agronômica Ceres, 1974

NEMIRO, J. E. Connection in creative virtual teams. Journal of Behavioral and Applied Management, 3(2), 92-112, winter/spring, 2001.

NICOLETTA, G. Alta nos grãos impulsiona vendas de máquinas agrícolas. Disponível em <http://www.estadao.com.br/economia/not_eco166013,0.htm >. Acesso em: 03 de maio de 2008.

OCDE. Manual de Oslo 2005. Disponível em < http://www.finep.gov.br/imprensa/sala_imprensa/manual_de_oslo.pdf $>$.Acesso em: 01 de julho de 2007.

OLIVEIRA, S. L. Tratado de metodologia científica. São Paulo: Pioneira. 1999.

PANT, I.; BAROUDI, B. Project management education: The human skills imperative. International Journal of Project Management 26, 124-128, 2008.

PARKER, H. Interfirm collaboration and the new product development process. Industrial Management and data Systems, 100/6, p. 255-260, 2000

PARTHASARTHY, R.; HAMMOND, J. Product innovation input and outcome: moderating effects of the innovation process. Journal Engineering. Technology Management, n. 19, p. 75-91, 2002.

PARUNG, J.; BITITCI, U. S. A conceptual metric for managing collaborative networks Journal of Modelling Management, v. 1, n. 2, p. 116-136, 2006.

PASQUAL, C.A.; PEDROSO, E.A. Características do negócio de máquinas agrícolas. RAE eletrônica, São Paulo, v. 6, n.1, art. 3, jan/jun, 2007. Disponível em <http:// www.rae.com.br/eletrônica>. Acesso em: 26 de junho de 2007.

PIGATTO, G. E ALCÂNTARA, R.L.C. Relacionamento colaborativo nos canais de distribuição. In: Zuin, L.F.S. e Queiroz, T.R. (coord). Agronegócio: gestão e inovação. São Paulo: Saraiva, 2006.

PMBOK. Um guia do conjunto de conhecimentos em gerenciamento de projetos. 3 edição. Project Management Institute, Inc., 2004.

POLZER, J.T. Creating teams with on edge. Boston: Harvard Business School Press, 2004. 
REVISTA FARM FÓRUM - Visão Global - Revista da CASE IH para o Brasil. A tropicalização dos líderes. Curitiba. ano 6, n.19. p. 4, 2007.

RIBEIRO, L. F. C. Estratégias competitivas na indústria de máquinas e implementos agrícolas do Rio Grande do Sul. , 117f. Dissertação (Mestrado) - Universidade Vale dos Sinos, 2006.

ROCKART, J. F. Chief executives define their own data needs - Harvard Business Review - março/abril, 1979.

ROESCH, S. M. A. Projetos de estágio e de pesquisa em Administração: Guia para estágios, trabalhos de conclusão, dissertações e estudos de caso. Colaboração: Garce Vieira Becker, Maria Ivone de Mello. 2 ed. São Paulo: Atlas, 1999.

ROMANO, L. N. Modelo de referência para o processo de desenvolvimento de máquinas agrícolas. 321f. Tese (Doutorado) - Universidade Federal de Santa Catarina, 2003.

et al. An introduction to the reference model for the agricultural machinery development process. Brazilian Journal of Product Development Management, v. 3, n. 2, dezembro, p. 109-132, 2005.

Ciclo de Vida. Revista Cultivar Máquinas, edição 51, ano V, abril, p. 36-39, 2006.

ROVAI, R.L. Modelo estruturado para a gestão de riscos em projetos: estudos de casos múltiplos. 365 f. Tese (Doutorado) - Escola Politécnica da Universidade de São Paulo, 2005.

ROZENFELD et al . Gestão de desenvolvimento de produtos: uma referência para a melhoria do processo. São Paulo: Editora Saraiva, 2006.

O processo de desenvolvimento de produtos. Revista Produtos \& Serviços, São Paulo, Banas, n. 312, p. 55-64, dez. 2000. (Edição especial: Fábrica do futuro: entenda hoje como sua indústria vai ser amanhã)

RUTTER, M.- Pesquisa de Mercado - Série Princípios - 2 ed. São Paulo: Ática, 1994.

SAVANACHI, E. Os motores do agronegócio. Revista Panorama Rural. São Paulo, ano IX, n. 100, p. 32-37, 2007.

SCHNEIDER, A. Project management in international teams: instruments for improving cooperation - International Journal of Project Management, v.13, n. 4, p. 247-251, 1995.

SCHUMPETER, J. A teoria do desenvolvimento econômico. Tradução: Maria Sílvia Possas. 3 ed. São Paulo: Nova Cultural, 1988.

SHENHAR, A. J.; DVIR, D. Project management research-the challenge and opportunity. Project Management Journal, p. 93; 38, 2, junho, 2007.

SIMÕES, J.M.S. Perfil de maturidade do processo de desenvolvimento de produtos em empresas de pequeno e médio porte do setor de máquinas e implementos agrícolas. 147 
p. Dissertação (Mestrado) - Engenharia de Produção. Universidade Federal de São Carlos, 2007.

SIVADAS, E.; DWYER, F.R. An examination of organizational factors influencing new product success in internal and Alliance-Based Processes. Journal of Marketing, 64(1)3149, 2000.

SRIVANNABOON, S.; MILOSEVIC, D.Z .Two-way influence between business strategy and project management. International Journal of Project Management. 24, p.493-505, 2006.

STULZER, V. Vendas de maquinas agrícolas em marco sobem ante fevereiro. Disponível em <http: // noticias.terra.com.br/interna/0,OI2727433-EI188,00>. Acesso em: 04 de abril de 2008 .

TOLEDO et al . A gestão do processo de desenvolvimento de produtos em empresas brasileiras de pequeno e médio porte do setor de máquinas e implementos agrícolas-XXVI ENEGEP, 2006. Disponível em < http://www.ifm.org.br/dotproject/fileviewer.php?_id=765>. Acesso em: 09 de julho de 2007.

TORRICO, R. Máquinas voltadas para o futuro. Revista Panorama Rural. São Paulo, ano IX, n. 100, p. 38-39. maio, 2007.

VAN WYK, R.; BOWEN, P.; AKINTOYE, A. Project risk management practice: The case of South African utility company. International Journal of Project Management. 26, p. 149163, 2008.

VERMUlM, R. A Indústria de Bens de Capital Seriado. Convênio CEPAL/IPEA, 2003. Disponível em <http://www.eclac.org/publicaciones/xml/4/21524/LCBRS147RobertoVermulm.pdf>. Acesso em: 19 de dezembro de 2007.

VERZUH, E. MBA compacto, gestão de projetos - tradução: André L. Cardoso - Rio de Janeiro: Elsevier, 2000

VON STAMM. Collaboration with other firms and customers: innovation's secret weapon. Strategy and Leadership. v. 32, n. 3, p. 16-20, 2004.

WANG, L. et al. Collaborative conceptual design: state of the art and future trends. Computer-Aided Design, v. 34, n.13, p. 981-996, 2002.

WOMACK, J.P. et al. A máquina que mudou o mundo; tradução de Ivo Korytowski. Rio de Janeiro: Campus, 1992.

YIN, R. K. Estudo de caso: planejamento e métodos - 3 ed. Porto Alegre: Bookman, 2005. 2001. Estudo de caso: planejamento e métodos - 2 ed. edição. Porto Alegre: Bookman, 


\section{APÊNDICES}

\section{Apêndice A - Roteiro de Pesquisa}

\section{CONSIDERAÇÕES INICIAIS}

Este roteiro tem como objetivo coletar dados para a pesquisa sobre "Gerenciamento de Projetos Colaborativos de Novos Produtos na Indústria de Máquinas Agrícolas”, que faz parte do programa de pesquisa do Programa Instituto Fábrica do Milênio (IFM - www.ifm.org.br), realizado em parceria com este instituto e a Associação Brasileira da Indústria de Máquinas e Equipamentos (ABIMAQ).

As informações obtidas serão exclusivamente para o entendimento acadêmico e com total sigilo. Os resultados das entrevistas serão compilados na forma de um relatório sobre a empresa e posteriormente serão enviados ao respondente para a análise e indicação de possíveis incorreções, informações complementares ou trechos que devam ser suprimidos (a empresa tenha o interesse em NÃO divulgar)

Somente os dados aprovados serão utilizados na compilação final. Ao término da pesquisa será enviado um relatório completo contendo os dados de todos os casos realizados. 


\section{CARACTERIZAÇÃO DA EMPRESA}

Objetivo: esta parte informa os dados institucionais da empresa, a estrutura organizacional, a descrição dos produtos e os tipos de projetos que realiza.

\subsection{Identificação}

\section{Razão Social:}

\begin{tabular}{|l|l|}
\hline Cidade: & Estado: \\
\hline Respondente: & Cargo: \\
\hline e-mail: & Fone: \\
\hline
\end{tabular}

\subsection{Estrutura Organizacional}

1.2.1 níveis hierárquicos e suas responsabilidades. 
1.2.2 colaboradores em cada uma das áreas definidas na tabela

\begin{tabular}{|c|c|c|}
\hline Áreas & Setores envolvidos & Colaboradores \\
\hline Apoio & $\begin{array}{l}\text { Financeira, } \\
\text { Jurídica } \\
\text { Recursos Humanos, } \\
\text { Tecnologia de Informação, }\end{array}$ & 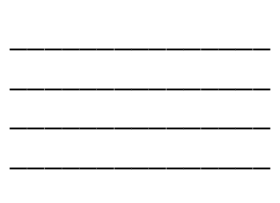 \\
\hline Campo & Pessoas em campo & \\
\hline $\begin{array}{c}\text { Pesquisa \& } \\
\text { Desenvolvimento }\end{array}$ & $\begin{array}{l}\text { Desenvolvimento de protótipos e testes, } \\
\text { Engenharia do produto e processo, } \\
\text { Tecnologia, }\end{array}$ & \\
\hline Produção & $\begin{array}{l}\text { Logística e Distribuição, } \\
\text { Planejamento da produção, } \\
\text { Suprimentos }\end{array}$ & \\
\hline $\begin{array}{c}\text { Vendas/Assistência } \\
\text { Técnica }\end{array}$ & $\begin{array}{l}\text { Assistência Técnica } \\
\text { Contratos, } \\
\text { Marketing, } \\
\text { Vendas }\end{array}$ & 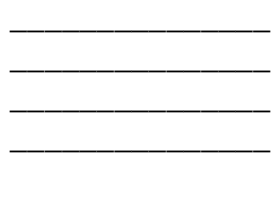 \\
\hline
\end{tabular}

\section{Comentários adicionais:}


1.2.3. Descrição dos Produtos

\begin{tabular}{|l|l|}
\hline Produtos & Segmentos (culturas agrícolas) \\
\hline & \\
\hline & \\
\hline & \\
\hline & \\
\hline & \\
\hline & \\
\hline & \\
\hline & \\
\hline & \\
\hline & \\
\hline & \\
\hline & \\
\hline & \\
\hline & \\
\hline & \\
\hline & \\
\hline & \\
\hline & \\
\hline & \\
\hline & \\
\hline & \\
\hline & \\
\hline & \\
\hline & \\
\hline & \\
\hline & \\
\hline & \\
\hline & \\
\hline & \\
\hline & \\
\hline & \\
\hline
\end{tabular}

Comentários adicionais: 


\subsection{Tipos de Projetos de desenvolvimento de produtos}

Preencher no quadro a seguir o total e porcentagens aproximadas de cada tipo de projetos nos últimos cinco (5) anos.

\begin{tabular}{|c|c|c|c|}
\hline Tipo & Descrição & Total & $\%$ \\
\hline $\begin{array}{l}\text { Montagem } \\
\text { industrial }\end{array}$ & $\begin{array}{l}\text { O projeto consiste em entender a necessidade do cliente e } \\
\text { projetar um equipamento a partir de componentes (ou } \\
\text { conjunto de outros equipamentos) padronizados, } \\
\text { comprados de catálogo de fornecedores ou produzidos } \\
\text { pela própria empresa. }\end{array}$ & & \\
\hline $\begin{array}{l}\text { Difusão } \\
\text { Tecnológica }\end{array}$ & $\begin{array}{l}\text { O produto é uma adaptação de produtos existentes, } \\
\text { licenciados de outras empresas ou de propriedade de } \\
\text { empresas do grupo. }\end{array}$ & & \\
\hline Extensão de linha & $\begin{array}{l}\text { O produto é uma evolução de produto anterior da empresa, } \\
\text { com acréscimos em desempenho, função ou capacidade } \\
\text { (não há mudança da tecnologia ou funções) }\end{array}$ & & \\
\hline $\begin{array}{l}\text { Nova tecnologia } \\
\text { para a empresa }\end{array}$ & $\begin{array}{l}\text { O produto possui inovações significativas para a empresa, } \\
\text { porém de domínio por parte de uma ou mais empresas no } \\
\text { mercado. }\end{array}$ & & \\
\hline $\begin{array}{l}\text { Nova tecnologia } \\
\text { para o mercado }\end{array}$ & $\begin{array}{l}\text { O produto possui inovações significativas para a empresa } \\
\text { e para o mercado. }\end{array}$ & & \\
\hline
\end{tabular}

\section{Comentários adicionais:}




\section{COLABORAÇÃO NA EMPRESA}

Objetivo: Esta parte tem objetivos identificar aspectos sobre a colaboração da empresa com outras organizações.

2.1 A empresa realiza projetos colaborativos de DP com outras organizações?

2.2 Quais são as motivações da empresa para isso?

2.3.Quais são os critérios utilizados para a escolha do parceiro?

2.4. No quadro abaixo, assinale os parceiros, a importância e os objetivos das colaborações em desenvolvimento de novos produtos.

\begin{tabular}{|c|c|c|c|c|c|c|c|c|c|c|}
\hline \multirow[b]{2}{*}{ Parceiro } & \multicolumn{4}{|c|}{ Importância } & \multicolumn{6}{|c|}{ Objetivo da colaboração } \\
\hline & 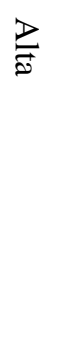 & $\underset{2}{\stackrel{3}{2}}$ & 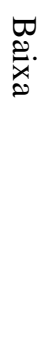 & 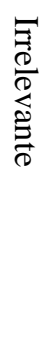 & $\rightleftarrows$ & 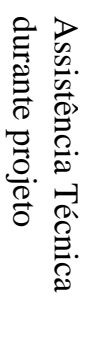 & 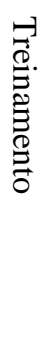 & 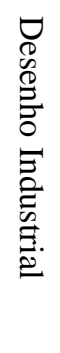 & 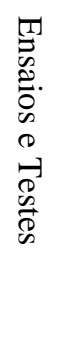 & 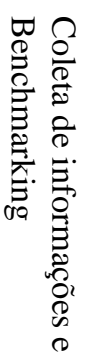 \\
\hline Clientes & & & & & & & & & & \\
\hline Fornecedores & & & & & & & & & & \\
\hline Empresas do grupo & & & & & & & & & & \\
\hline Empresas de consultoria & & & & & & & & & & \\
\hline Universidade e institutos de pesquisa & & & & & & & & & & \\
\hline $\begin{array}{l}\text { Centros de capacitação profissional e } \\
\text { assistência técnica (SENAI e Núcleos } \\
\text { afins) }\end{array}$ & & & & & & & & & & \\
\hline
\end{tabular}

\section{Comentários adicionais:}




\section{CLASSIFICAÇÃO DO PROJETO}

Objetivo: Esta parte tem por objetivo descrever um projeto colaborativo de DP com duas características: a)ser considerado de sucesso, isto é, na opinião do entrevistado tenha obtido os resultados esperados e tenha sido significativo para a empresa; b) possui um grau de inovação e complexidade.

\subsection{Tipologia do Projeto}

\begin{tabular}{|l|c|}
\hline \multicolumn{1}{|c|}{ Tipo } & $\begin{array}{c}\text { Assinale a porcentagem dos } \\
\text { projetos }\end{array}$ \\
\hline Montagem Industrial & \\
\hline Difusão Tecnológica & \\
\hline Extensão de Linha & \\
\hline Nova tecnologia para a empresa & \\
\hline Nova tecnologia para o mercado & \\
\hline
\end{tabular}

\subsection{Objetivo da colaboração no projeto}

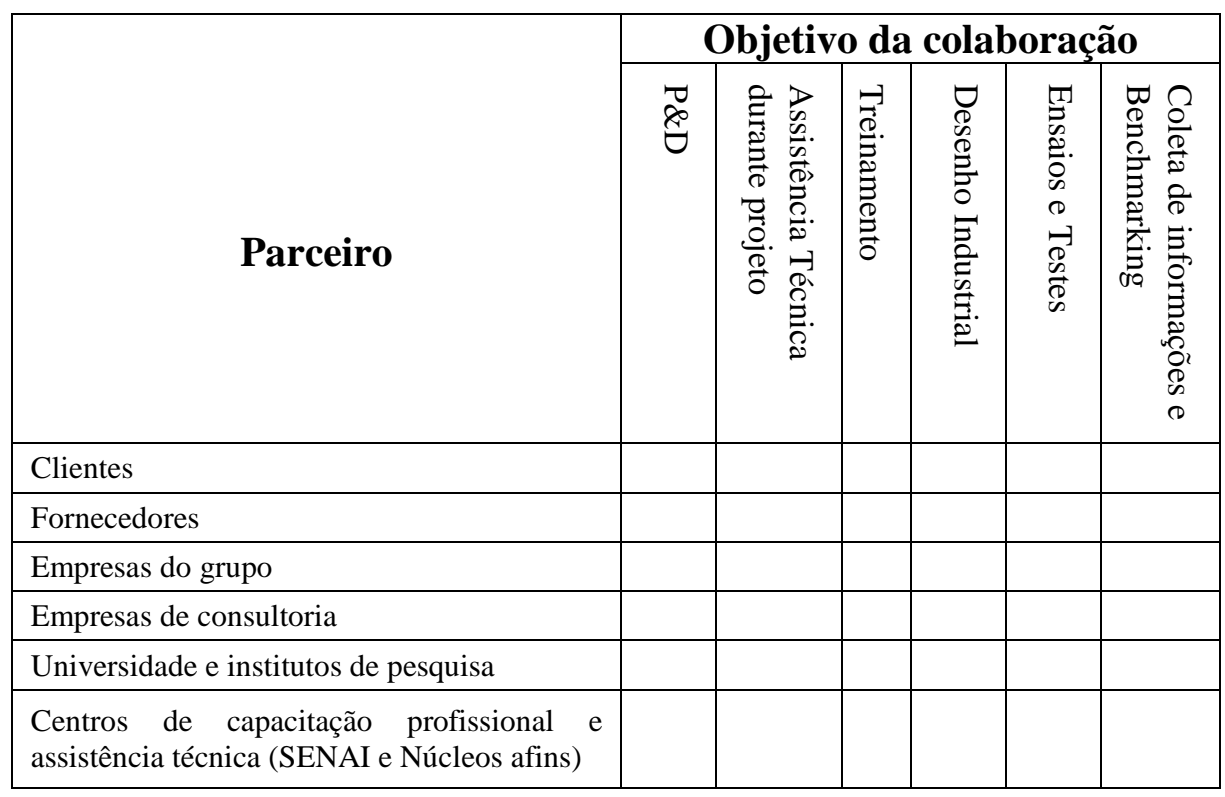

3.2.1. O projeto foi distribuído em localizações geográficas distintas ou foi centralizado?

3.2.2. As equipes trabalhavam em tempo integral ou não no projeto? Como se comunicavam?

3.2.3. Quantas pessoas formavam as equipes e quais os papéis desempenhados?

3.2.4. Qual foi o tempo de duração do projeto?

3.2.5. Como foram feitas as reuniões entre a empresa e o parceiro com o intuito de definir os objetivos e as responsabilidades do projeto? Como eram formalizadas? 


\section{AVALIAÇÃO DOS FATORES CRÍTICOS DE SUCESSO}

Objetivo: descrever os FCS com o(s) parceiro(s) do projeto; os beneficios para a empresa e o parceiro; as dificuldades encontradas para gerenciar o projeto..

4.1. A seguir há um conjunto de afirmações sobre o projeto em questão. Em cada afirmação escolha um nível de 1 a 5, conforme a escala da tabela, expressando a sua opinião sobre o que aconteceu no projeto. Em seguida, justifique a resposta.

1 - discordo totalmente

2 - discordo

3 - indiferente

4 - concordo parcialmente

5 - concordo totalmente 


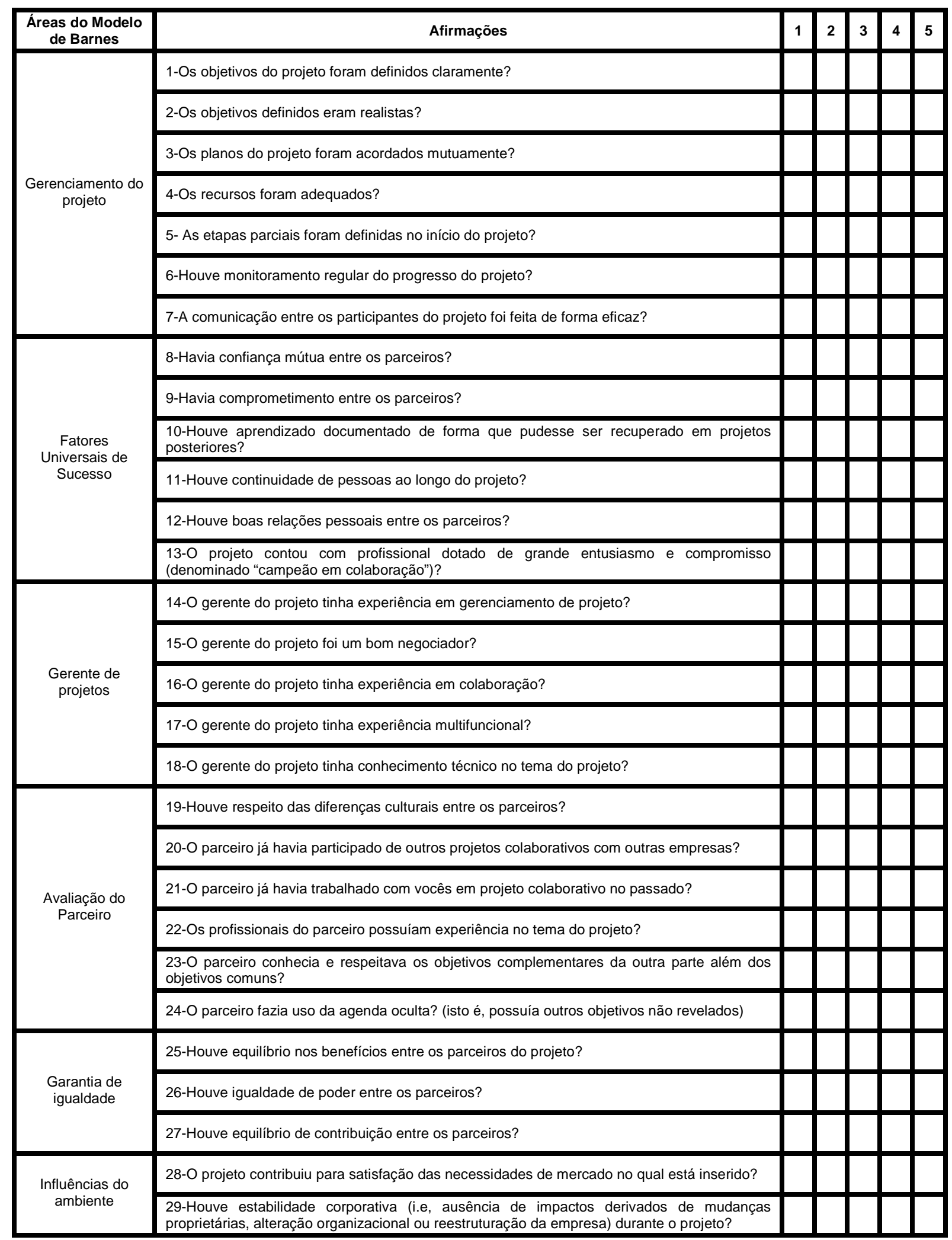


4.2. Em algum momento durante o ciclo de vida do projeto, foram utilizados procedimentos formais (brainstorming, Técnica Delphi, entrevistas, checklists, análise de premissas, técnicas de diagramação) que pudessem auxiliar na identificação, administração ou minimização de riscos futuros (ex: riscos técnicos, organizacionais, externos, de gerência de produtos)?

4.3. Com qual a freqüência a equipe e/ou parceiro fizeram uso disto?

4.4.Em sua opinião quais os benefícios advindos dessa colaboração para empresa e o parceiro?
a)Financeiros
b)Inovação tecnológica
c)Conhecimento
d)Recursos Humanos

4.5. Qual a dificuldade encontrada pela empresa para gerenciar o projeto? 